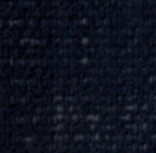




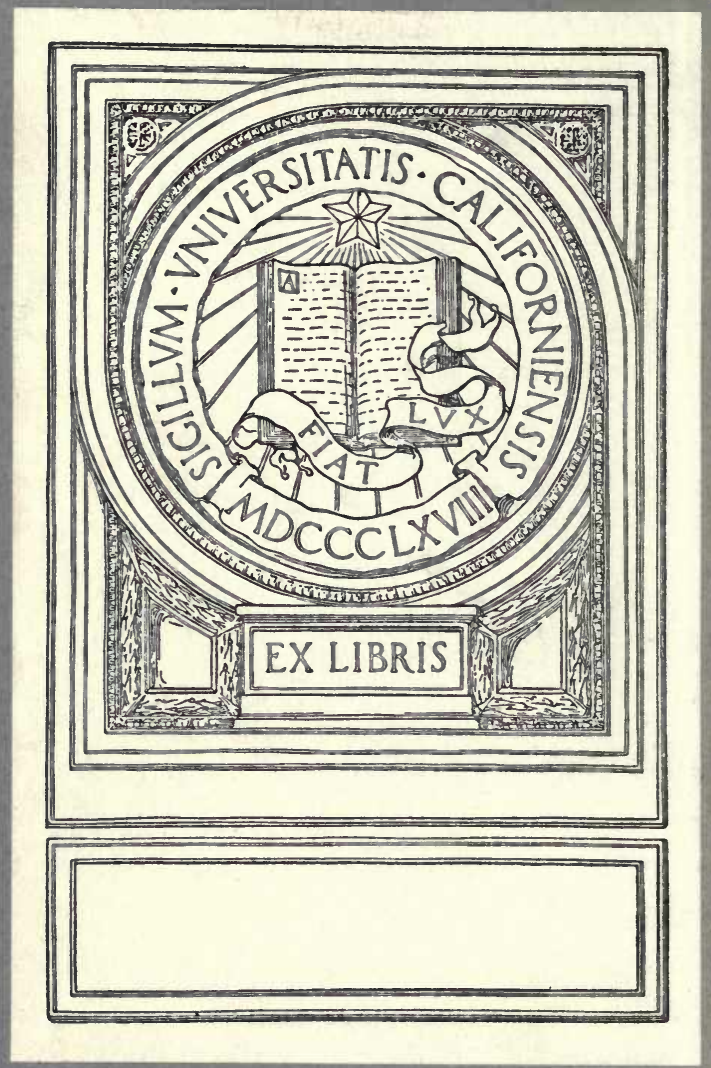






\title{
AN INTRODUCTION TO
}

\section{THE HISTORY OF SCIENCE .}

\author{
BY \\ WALTER LIBBY, M.A., Ph.D. \\ PROFESSOR OF THE HISTORY OF SCIENCE \\ IN THE CARNEGIE INSTITUTE \\ OF TECHNOLOGY
}

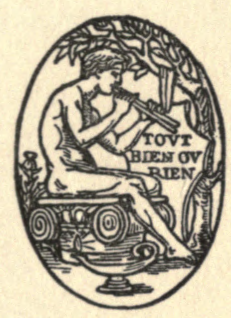

BOSTON NEW YORK CHICAGO

HOUGHTON MIFFLIN COMPANY

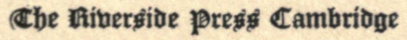




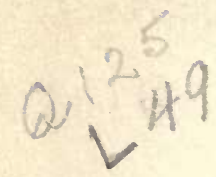

COPYRIGHT, I9I7, BY WALTER LIBEY

ALL RIGHTS RESERVED

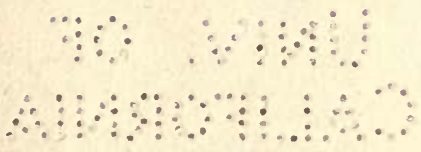

Cbe 3ibersite Press

CAMBRIDGE - MASSACHUSRTTS

U . S . A 
TO MY STUDENTS OF THE LAST TWELVE YEARS IN THE CHICAGO AND PITTSBURGH DISTRICTS THIS BOOK IS INSCRIBED IN FURTHERANCE OF THE ENDEAVOR TO INCULCATE A DEMOCRATIC CULTURE, EVER MINDFUL OF THE DAILY TASK, NOT ALTOGETHER IGNORANT OF THE ACHIEVEMENTS OF THE PAST 



\section{PREFACE}

The history of science has something to offer to the humblest intelligence. It is a means of imparting a knowledge of scientific facts and principles to unschooled minds. At the same time it affords a simple method of school instruction. Those who understand a business or an institution best, as a contemporary writer on finance remarks, are those who have made it or grown up with it, and the next best thing is to know how it has grown up, and then watch or take part in its actual working. Generally speaking, we know best what we know in its origins.

The history of science is an aid in scientific research. It places the student in the current of scientific thought, and gives him a clue to the purpose and necessity of the theories he is required to master. It presents science as the constant pursuit of truth rather than the formulation of truth long since revealed; it shows science as progressive rather than fixed, dynamic rather than static, a growth to which each may contribute. It does not paralyze the selfactivity of youth by the record of an infallible past.

It is only by teaching the sciences in their historical development that the schools can be true to the two principles of modern education, that the sciences should occupy the foremost place in the curriculum and that the individual mind in its evolution should rehearse the history of civilization.

The history of science should be given a larger place than at present in general history; for, as 
Bacon said, the history of the world without a history of learning is like a statue of Polyphemus with the eye out. The history of science studies the past for the sake of the future. It is a story of continuous progress. It is rich in biographical material. It shows the sciences in their interrelations, and saves the student from narrowness and premature specialization. It affords a unique approach to the study of philosophy. It gives new motive to the study of foreign languages. It gives an interest in the applications of knowledge, offers a clue to the complex civilization of the present, and renders the mind hospitable to new discoveries and inventions.

The history of science is hostile to the spirit of caste. It shows the sciences rising from daily needs and occupations, formulated by philosophy, enriching philosophy, giving rise to new industries, which react in turn upon the sciences. The history of science reveals men of all grades of intelligence and of all social ranks coöperating in the cause of human progress. It is a basis of intellectual and social homogeneity.

Science is international, English, Germans, French, Italians, Russians - all nations - contributing to advance the general interests. Accordingly, a survey of the sciences tends to increase mutual respect, and to heighten the humanitarian sentiment. The history of science can be taught to people of all creeds and colors, and cannot fail to enhance in the breast of every young man, or woman, faith in human progress and good-will to all mankind.

This book is intended as a simple introduction, taking advantage of the interests of youth of from 
seventeen to twenty-two years of age (and their intellectual compeers) in order to direct their attention to the story of the development of the sciences. It makes no claim to be in any sense complete or comprehensive. It is, therefore, a psychological introduction, having the mental capacity of a certain class of readers always in view, rather than a logical introduction, which would presuppose in all readers both full maturity of intellect and considerable initial interest in the history of science.

I cannot conclude this preface without thanking those who have assisted me in the preparation of this book - Sir William Osler, who read the first draft of the manuscript, and aided me with his counsel ; Dr. Charles Singer, who read all the chapters in manuscript, and to whom I am indebted for advice in reference to the illustrations and for many other valuable suggestions; the officers of the Bodleian Library, whose courtesy was unfailing during the year I worked there; Professor Henry Crew, who helped in the revision of two of the chapters by his judicious criticism; Professor J. E. Rush, whose knowledge of bacteriology improved the chapter on Pasteur; Professor L. O. Grondahl, who read one of the chapters relating to the history of physics and suggested important emendations; and Dr. John A. Brashear, who contributed valuable information in reference to the activities of Samuel Pierpont Langley. I wish to express my gratitude also to Miss Florence Bonnet for aid in the correction of the manuscript.

February 2, 1917.

W. LiвBy. 


\section{CONTENTS}

I. Science and Practical Needs-Egypt AND BABYLONIA . . • . . . . . 1

II. The Influence of Abstract Thought -

Greece: Aristotle • • . . . 15

III. Sctentific Theory Subordinated to An Plication - Rome: Vitruvius . . . 30

IV. The Continuity of Science - The Medieval Church and the Arabs . . . 43

V. The Classification of the SciencesFrancis Bacon . . . . . . 57

VI. Scientific Method-Gilbert, Galileo, Harvey, Descartes •. . . . 72

VII. Science as Measurement - Tycho Brahe, Kepler, Boyle . . . . . . . 86

VIII. Coöperation IN Science-The Royal SOCIETY . . . . . . . . . 99

IX. Science ANd the Struggle for Liberty Benjamin Franklin . • • . • . 114

X. The Interaction of the Sciences Werner, Hutton, Black, Hall, William SMith • • • • • • • • • • . 129

XI. Science and Religion - Kant, Lambert, Laplace, Sir William Herschel . . 142 XII. The Reign of Law - Dalton, Joule • 155 
XIII. The Scientist - Sir Humphry Davy . 170

XIV. Scientific Prediction - The Discovery of Neptune • . . . . . . . 184

XV. Science and Travel - The Voyage of the Beagle • . . . . . . . . 197

XVI. Science and War-Pasteur, Lister . 213

XVII. Science and Invention - Langley's AeroPLANE . • • • • • • • • . 231

XVIII Scientific Hypothesis - Radioactive SubSTANCES . . . . . . . . 245

XIX. The Screntific Imagination . • . 258

XX. Science and Democratic Culture • . 270 INDEX . . . . . . . . 283 


\section{ILLUSTRATIONS}

Earliest Picture known of a Surgical Operation. Egypt, 2500 B.c. . . . . . . . . 6 St. Thomas Aquinas overcoming Averroüs • 54

Dr. Gilbert showing his Electrical Experiments to Queen Elizabeth and her Court . . . 72 The Tichonic Quadrant. . . . . . . 88 Wadham College, Oxford . . . . . . . . 104 Sir Isaac Newton . . . . . . . . . . . 112 John Dalton collecting Marsh Gas . . . 162 The First Successfful Heavier-than-air Flying MACHINE . . . . . . . . . . . . 236 



\section{AN INTRODUCTION TO THE HISTORY OF SCIENCE}

\section{CHAPTER I}

SCIENCE AND PRACTICAL NEEDS - EGYPT AND BABYLONIA

If you consult encyclopedias and special works in reference to the early history of any one of the sciences, - astronomy, geology, geometry, physiology, logic, or political science, for example, - you will find strongly emphasized the part played by the Greeks in the development of organized knowledge. Great, indeed, as we shall see in the next chapter, are the contributions to the growth of science of this highly rational and speculative people. It must be conceded, also, that the influence on Western science of civilizations earlier than theirs has come to us, to a considerable extent at least, through the channels of Greek literature.

Nevertheless, if you seek the very origins of the sciences, you will inevitably be drawn to the banks of the Nile, and to the valleys of the Tigris and the Euphrates. Here, in Egypt, in Assyria and Babylonia, dwelt from very remote times nations whose genius was practical and religious rather than intellectual and theoretical, and whose mental life, therefore, was more akin to our own than was the highly evolved culture of the Greeks. Though more remote in time, 


\section{$\therefore$ THE HISTORY OF SCIENCE}

the wisdom and practical knowledge of Thebes and Memphis, Nineveh and Babylon, are more readily comprehended by our minds than the difficult speculations of Athenian philosophy.

Much that we have inherited from the earliest civilizations is so familiar, so homely, that we simply accept it, much as we may light, or air, or water, without analysis, without inquiry as to its origin, and without full recognition of how indispensable it is. Why are there seven days in the week, and not eight? Why are there sixty minutes in the hour, and why are there not sixty hours in the day? These artificial divisions of time are accepted so unquestioningly that to ask a reason for them may, to an indolent mind, seem almost absurd. This acceptance of a week of seven days and of an hour of sixty minutes (almost as if they were natural divisions of time like day and night) is owing to a tradition that is Babylonian in its origin. From the Old Testament (which is one of the greatest factors in preserving the continuity of human culture, and the only ancient book which speaks with authority concerning Babylonian history) we learn that Abraham, the progenitor of the $\mathrm{He}$ brews, migrated to the west from southern Babylonia about twenty-three hundred years before Christ. Even in that remote age, however, the Babylonians had established those divisions of time which are familiar to us. The seven days of the week were closely associated in men's thinking with the heavenly bodies. In our modern languages they are named after the sun, the moon, Mars, Mercury, Jupiter, Venus, and Saturn, which from the remotest times were personified and worshiped. Thus we see that 
the usage of making seven days a unit of time depends on the religious belief and astronomical science of a very remote civilization. The usage is so completely established that by the majority it is simply taken for granted.

Another piece of commonplace knowledge - the cardinal points of the compass - may be accepted, likewise, without inquiry or without recognition of its importance. Unless thrown on your own resources in an unsettled country or on unknown waters, you may long fail to realize how indispensable to the practical conduct of life is the knowledge of east and west and north and south. In this matter, again, the records of ancient civilizations show the pains that were taken to fix these essentials of science. Modern excavations have demonstrated that the sides or the corners of the temples and palaces of Assyria and Babylonia were directed to the four cardinal points of the compass. In Egypt the pyramids, erected before 3000 B.C., were laid out with such strict regard to direction that the conjecture has been put forward that their main purpose was to establish, in a land of shifting sands, east and west and north and south. That conjecture seems extravagant; but the fact that the Phœnicians studied astronomy merely because of its practical value in navigation, the early invention of the compass in China, the influence on discovery of the later improvements of the compass, make us realize the importance of the alleged purpose of the pyramids. Without fixed points, without something to go by, men, before they had acquired the elements of astronomy, were altogether at sea. As they advanced in knowledge they looked to the stars for 


\section{THE HISTORY OF SCIENCE}

guidance, especially to the pole star and the imperishable star-group of the northern heavens. The Egyptians even developed an apparatus for telling the time by reference to the stars - a star-clock similar in its purpose to the sundial. By the Egyptians, also, was carefully observed the season of the year at which certain stars and constellations were visible at dawn. This was of special importance in the case of Sirius, for its heliacal rising, that is, the period when it rose in conjunction with the sun, marked the coming of the Nile flood (so important in the lives of the inhabitants) and the beginning of a new year. Not unnaturally Sirius was an object of worship. One temple is said to have been so constructed as to face that part of the eastern horizon at which this star arose at the critical season of inundation. Of another temple we are told that only at sunset at the time of the summer solstice did the sun throw its rays throughout the edifice. The fact that astronomy in Egypt as in Babylonia, where the temples were observatories, was closely associated with religion confirms the view that this science was first cultivated because of its bearing on the practical needs of the people. The priests were the preservers of such.wisdom as had been accumulated in the course of man's immemorial struggle with the forces of nature.

It is well known that geometry had its origin in the valley of the Nile, that it arose to meet a practical need, and that it was in the first place, as its name implies, a measurement of the earth - a crude surveying, employed in the restoration of boundaries obliterated by the annual inundations of the river. 
Egyptian geometry cared little for theory. It addressed itself to actual problems, such as determining the area of a square or triangular field from the length of the sides. To find the area of a circular field, or floor, or vessel, from the length of the diameter was rather beyond the science of 2000 B.C. This was, however, a practical problem which had to be solved, even if the solution were not perfect. The practice was to square the diameter reduced by one ninth.

In all the Egyptian mathematics of which we have record there is to be observed a similar practical bent. In the construction of a temple or a pyramid not merely was it necessary to have regard to the points of the compass, but care must be taken to have the sides at right angles. This required the intervention of specialists, expert " rope-fasteners," who laid off a triangle by means of a rope divided into three parts, of three, four, and five units. The Babylonians followed much the same practice in fixing a right angle. In addition they learned how to bisect and trisect the angle. Hence we see in their designs and ornaments the division of the circle into twelve parts, a division which does not appear in Egyptian ornamentation till after the incursion of Babylonian influence.

There is no need, however, to multiply examples; the tendency of all Egyptian mathematics was, as already stated, concerned with the practical solution of concrete problems - mensuration, the cubical contents of barns and granaries, the distribution of bread, the amounts of food required by men and animals in given numbers and for given periods of time, the proportions and the angle of elevation (about $52^{\circ}$ ) of a pyramid, etc. Moreover, they worked simple 
equations involving one unknown, and had a hieroglyph for a million (the drawing of a man overcome with wonder), and another for ten million.

The Rhind mathematical papyrus in the British Museum is the main source of our present knowledge of early Egyptian arithmetic, geometry, and of what might be called their trigonometry and algebra. It describes itself as "Instructions for arriving at the knowledge of all things, and of things obscure, and of all mysteries." It was copied by a priest about 1600 B.c. - the classical period of Egyptian culture - from a document seven hundred years older.

Medicine, which is almost certain to develop in the early history of a people in response to their urgent needs, has been justly called the foster-mother of many sciences. In the records of Egyptian medical practice can be traced the origin of chemistry, anatomy, physiology, and botany. Our most definite information concerning Egyptian medicine belongs to the same general period as the mathematical document to which we have just referred. It is true something is known of remoter times. The first physician of whom history has preserved the name, I-en-hetep (He-who-cometh-in-peace), lived about 4500 B.c. Recent researches have also brought to light, near Memphis, pictures, not later than 2500 B.c., of surgical operations. They were found sculptured on the doorposts at the entrance to the tomb of a high official of one of the Pharaohs. The patients, as shown in the accompanying illustration, are suffering pain, and, according to the inscription, one cries out, "Do this [and] let me go," and the other, "Don't hurt me so!" Our most satisfactory data in reference to Egyp- 


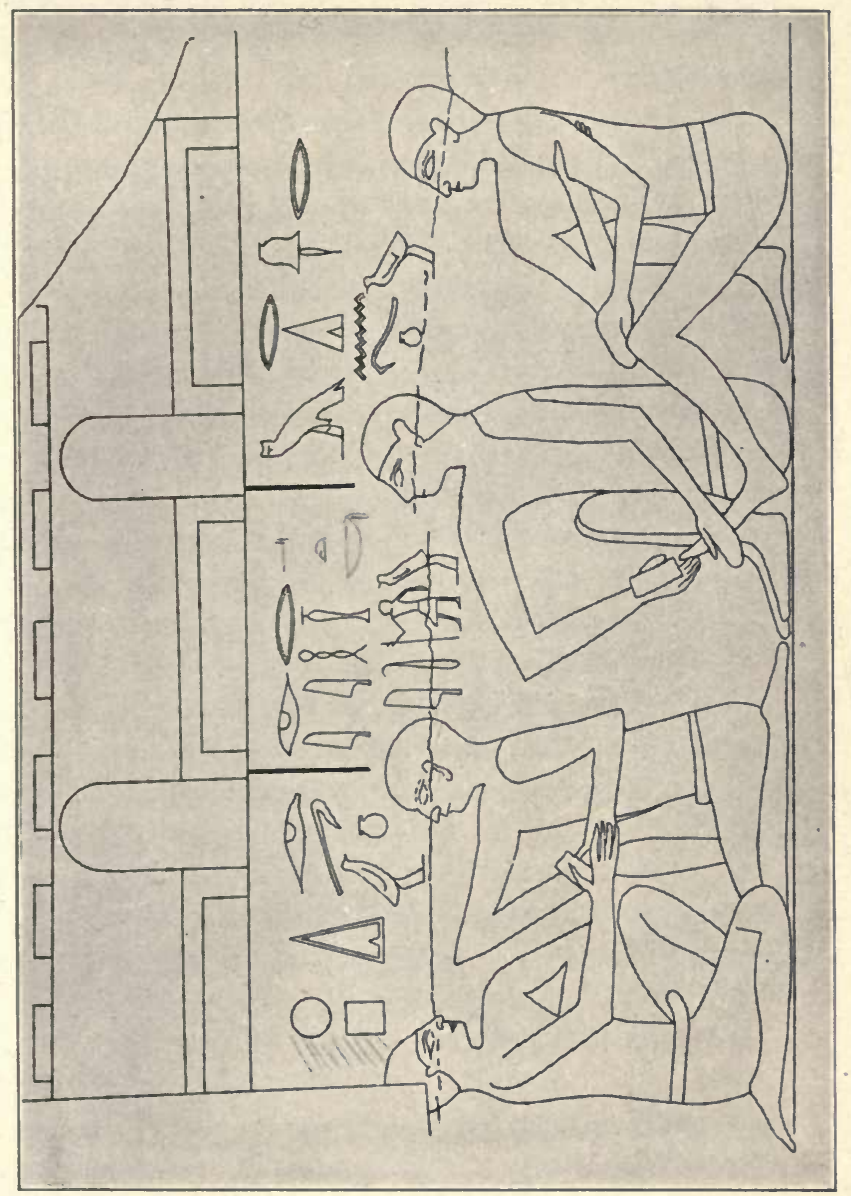

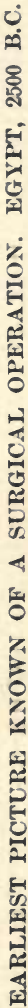


tian medicine are derived, however, from the Ebers papyrus. This document displays some little knowledge of the pulse in different parts of the body, of a relation between the heart and the other organs, and of the passage of the breath to the lungs (and heart). It contains a list of diseases. In the main it is a collection of prescriptions for the eyes, ears, stomach, to reduce tumors, effect purgation, etc. There is no evidence of a tendency to homeopathy, but mental healing seems to have been called into play by the use of numerous spells and incantations. Each prescription, as in medical practice to-day, contains as a rule several ingredients. Among the seven hundred recognized remedies are to be noted poppy, castoroil, gentian, colchicum, squills, and many other familiar medicinal plants, as well as bicarbonate of soda, antimony, and salts of lead and copper. The fat of the lion, hippopotamus, crocodile, goose, serpent, and wild goat, in equal parts, served as a prescription for baldness. In the interests of his art the medical practitioner ransacked the resources of organic and inorganic nature. The Ebers papyrus shows that the Egyptians knew of the development of the beetle from the egg, of the blow-fly from the larva, and of the frog from the tadpole. Moreover, for precision in the use of medicaments weights of very small denominations were employed.

The Egyptian embalmers relied on the preservative properties of common salt, wine, aromatics, myrrh, cassia, etc. By the use of linen smeared with gum they excluded all putrefactive agencies. They understood the virtue of extreme dryness in the exercise of their antiseptic art. Some knowledge of 
anatomy was involved in the removal of the viscera, and much more in a particular method they followed in removing the brain.

In their various industries the Egyptians made use of gold, silver, bronze (which on analysis is found to consist of copper, tin, and a trace of lead, etc.), metallic iron and copper and their oxides, manganese, cobalt, alum, cinnabar, indigo, madder, brass, white lead, lampblack. There is clear evidence that they smelted iron ore as early as 3400 B.C. maintaining a blast by means of leather tread-bellows. They also contrived to temper the metal, and to make helmets, swords, lance-points, ploughs, tools, and other implements of iron. Besides metallurgy they practiced the arts of weaving, dyeing, distillation. They produced soap (from soda and oil), transparent and colored glass, enamel, and ceramics. They were skilled in the preparation of leather. They showed aptitude for painting, and for the other fine arts. They were expert builders, and possessed the engineering skill to erect obelisks weighing hundreds of tons. They cultivated numerous vegetables, grains, fruits, and flowers. They had many domestic animals. In seeking the satisfaction of their practical needs they laid the foundation of geometry, botany, chemistry (named, as some think, from the Egyptian Khem, the god of medicinal herbs), and other sciences. But their practical achievements far transcended their theoretical formulations. To all time they will be known as an artistic, noble, and religious people, who cherished their dead and would not allow that the good and beautiful and great should altogether pass away. 


\section{SCIENCE AND PRACTICAL NEEDS}

Excavations in Assyria and Babylonia, especially since 1843, have brought to our knowledge an ancient culture stretching back four or five thousand years before the beginning of the Christian era. The records of Assyria and Babylonia, like those of Egypt, are fragmentary and still in need of interpretation. Here again, however, it is the fundamental, the indispensable, the practical forms of knowledge that stand revealed rather than the theoretical, speculative, and purely intellectual.

By the Babylonian priests the heavens were made the object of expert observation as early as 3800 B.C. The length of the year, the length of the month, the coming of the seasons, the course of the sun in the heavens, the movements of the planets, the recurrence of eclipses, comets, and meteors, were studied with particular care. One motive was the need of a measurement of time, the same motive as underlies the common interest in the calendar and almanac. It was found that the year contained more than 365 days, the month (synodic) more than 29 days, 12 hours, and 44 minutes. The sun's apparent diameter was contained 720 times in the ecliptic, that is, in the apparent path of the sun through the heavens. Like the Egyptians, the Babylonians took special note of the stars and star-groups that were to be seen at dawn at different times of the year. These constellations, lying in the imaginary belt encircling the heavens on either side of the ecliptic, bore names corresponding to those we have adopted for the signs of the zodiac, - Balance, Ram, Bull, Twins, Scorpion, Archer, etc. The Babylonian astronomers also observed that the successive vernal (or autumnal) 
equinoxes follow each other at intervals of a few seconds less than a year.

A second motive that influenced the Babylonian priests in studying the movements of the heavenly bodies was the hope of foretelling events. The planets, seen to shift their positions with reference to the other heavenly bodies, were called messengers, or angels. The appearance of Mars, perhaps on account of its reddish color, was associated in their imaginations with war. Comets, meteors, and eclipses were considered as omens portending pestilence, national disaster, or the fate of kings. The fortunes of individuals could be predicted from a knowledge of the aspect of the heavens at the hour of their birth. This interest in astrology, or divination by means of the stars, no doubt stimulated the priests to make careful observations and to preserve religiously the record of astronomical phenomena. It was even established that there is a cycle in which eclipses, solar and lunar, repeat themselves, a period (saros) somewhat more than eighteen years and eleven months. Moreover, from the Babylonians we derive some of our most sublime religious and scientific conceptions. They held that strict law governs the apparently erratic movements of the heavenly bodies. Their creation myth proclaims: "Merodach next arranged the stars in order, along with the sun and moon, and gave them laws which they were never to transgress."

The mathematical knowledge of the Babylonians is related on the one hand to their astronomy and on the other to their commercial pursuits. They possessed highly developed systems of measuring, weighing, 
and counting - processes, which, as we shall see in the sequel, are essential to scientific thought. About 2300 B.c. they had multiplication tables running from 1 to 1350 , which were probably used in connection with astronomical calculations. Unlike the Egyptians they had no symbol for a million, though the "ten thousand times ten thousand" of the Bible (Daniel vII : 10) may indicate that the conception of even larger numbers was not altogether foreign to them. They counted in sixties as well as in tens. Their hours and minutes had each sixty subdivisions. They divided the circle into six parts and into sixtimes-sixty subdivisions. Tables of squares and cubes discovered in southern Babylonia were interpreted correctly only on a sexagesimal basis, the statement that 1 plus 4 is the square of 8 implying that the first unit is 60 . As we have already seen, considerable knowledge of geometry is apparent in Babylonian designs and constructions.

According to a Greek historian of the fifth century B.C., there were no physicians at Babylon, while a later Greek historian (of the first century B.c.) speaks of a Babylonian university which had attained celebrity, and which is now believed to have been a school of medicine. Modern research has made known letters by a physician addressed to an Assyrian king in the seventh century B.c. referring to the king's chief physician, giving directions for the treatment of a bleeding from the nose from which a friend of the prince was suffering, and reporting the probable recovery of a poor fellow whose eyes were diseased. Other letters from the same general period mention the presence of physicians at court. We have 
even recovered the name (Ilu-bani) of a physician who lived in southern Babylonia about 2700 B.C. The most interesting information, however, in reference to Babylonian medicine dates from the time of Hammurabi, a contemporary of the patriarch Abraham. It appears from the code drawn up in the reign of that monarch that the Babylonian surgeons operated in case of cataract; that they were entitled to twenty silver shekels (half the sum for which Joseph was sold into slavery, and equivalent to seven or eight dollars) for a successful operation; and that in case the patient lost his life or his sight as the result of an unsuccessful operation, the surgeon was condemned to have his hands amputated.

The Babylonian records of medicine like those of astronomy reveal the prevalence of many superstitious beliefs. The spirits of evil bring maladies upon us; the gods heal the diseases that afflict us. The Babylonian books of medicine contained strange interminglings of prescription and incantation. The priests studied the livers of sacrificial animals in order to divine the thoughts of the gods - a practice which stimulated the study of anatomy. The maintenance of state menageries no doubt had a similar influence on the study of the natural history of animals.

The Babylonians were a nation of agriculturists and merchants. Sargon of Akkad, who founded the first Semitic empire in Asia (3800 B.C.), was brought up by an irrigator, and was himself a gardener. Belshazzar, the son of the last Babylonian king, dealt in wool on a considerable scale. Excavation in the land watered by the Tigris and Euphrates tells the tale of the money-lenders, importers, dyers, fullers, 
tanners, saddlers, smiths, carpenters, shoemakers, stonecutters, ivory-cutters, brickmakers, porcelainmakers, potters, vintners, sailors, butchers, engineers, architects, painters, sculptors, musicians, dealers in rugs, clothing and fabrics, who contributed to the culture of this great historic people. It is not surprising that science should find its matrix in so rich a civilization.

The lever and the pulley, lathes, picks, saws, hammers, bronze operating-lances, sundials, water-clocks, the gnomon (a vertical pillar for determining the sun's altitude) were in use. Gem-cutting was highly developed as early as 3800 в.c. The Babylonians made use of copper hardened with antimony and tin, lead, incised shells, glass, alabaster, lapis-lazuli, silver, and gold. Iron was not employed before the period of contact with Egyptian civilization. Their buildings were furnished with systems of drains and flushes that seem to us altogether modern. Our museums are enriched by specimens of their handicraft - realistic statuary in dolerite of 2700 B.c.; rock crystal worked to the form of a plano-convex lens, 3800 B.c.; a beautiful silver vase of the period 3950 B.C.; and the head of a goat in copper about 4000 B.C.

Excavation has not disclosed nor scholarship interpreted the full record of this ancient people in the valley of the Tigris and the Euphrates, not far from the Gulf of Persia, superior in religious inspiration, not inferior in practical achievements to the Egyptians. Both these great nations of antiquity, however, failed to earry the sciences that arose in connection with their arts to a high degree of generalization. That was reserved for another people of ancient times, namely, the Greeks. 


\section{THE HISTORY OF SCIENCE}

\section{REFERENCES}

F. H. Garrison, An Introduction to the History of Medicine.

H. V. Hilprecht, Excavations in Assyria and Babylonia.

Max Neuburger, History of Medicine.

A. H. Sayce, Babylonians and Assyrians. 


\section{CHAPTER II}

\section{THE INFLUENCE OF ABSTRACT THOUGHT -}

\section{GREECE : ARISTOTLE}

No sooner did the Greeks turn their attention to the sciences which had originated in Esypt and Babylonia than the characteristic intellectual quality of the Hellenic genius revealed itself. Thales (640-546 B.C.), who is usually regarded as the first of the Greek philosophers, was the founder of Greek geometry and astronomy. He was one of the seven "wise men" of Greece, and might be called the Benjamin Franklin of antiquity, for he was interested in commerce, famous for political sagacity, and honored for his disinterested love of general truth. His birthplace was Miletus, a Greek city on the coast of Asia Minor. There is evidence that he acquired a knowledge of Babylonian astronomy. The pursuit of commerce carried him to Egypt, and there he gained a knowledge of geometry. Not only so, but he was able to advance this study by generalizing and formulating its truths. For the Egyptians, geometry was concerned with surfaces and dimensions, with areas and cubical contents; for the Greek, with his powers of abstraction, it became a study of line and angle. For example, Thales saw that the angles at the base of an isosceles triangle are equal, and that when two straight lines cut one another the vertically opposite angles are equal. However, after having established general principles, he showed him- 


\section{THE HISTORY OF SCIENCE}

self capable of applying them to the solution of particular problems. In the presence of the Egyptian priests, to which class he was solely indebted for instruction, Thales demonstrated a method of measuring the height of a pyramid by reference to its shadow. And again, on the basis of his knowledge of the relation of the sides of a triangle to its angles, he developed a practical rule for ascertaining the distance of a ship from the shore.

The philosophical mind of Thales laid hold, no doubt, of some of the essentials of astronomical science. The particulars usually brought forward to prove his originality tend rather to show his indebtedness to the Babylonians. The number of days in the year, the length of the synodic month, the relation of the sun's apparent diameter to the ecliptic, the times of recurrence of eclipses, were matters that had long been known to the Babylonians, as well as to the Chinese. However, he aroused great interest in astronomy among the Greeks by the prediction of a solar eclipse. This was probably the eclipse of 585 B.c., which interrupted a fierce battle between the Medes and the Lydians. The advice of Thales to mariners to steer by the Lesser Bear, as nearer the pole, rather than by the Great Bear, shows also that in his astronomical studies as in his geometrical he was not indifferent to the applications of scientific knowledge.

In fact, some writers maintain that Thales was not a philosopher at all, but rather an astronomer and engineer. We know very little of his purely speculative thought. We do know, however, that he arrived at a generalization - fantastic to most minds 
- that all things are water. Attempts have been made to add to this statement, and to explain it away. Its great interest for the history of thought lies in the fact that it is the result of seeking the constant in the variable, the unitary principle in the multiple phenomena of nature. This abstract and general view (though perhaps suggested by the Babylonian belief that the world originated in a watery chaos, or by the teaching of Egyptian priests) was preëminently Greek, and was the first of a series of attempts to discover the basis or origin of all things. One of the followers of Thales taught that air was the fundamental principle; while Heraclitus, anticipating to some extent modern theories of the origin of the cosmos, declared in favor of a fiery vapor subject to ceaseless change. Empedocles, the great philosopher-physician, first set forth the doctrine of the four elements - earth, air, fire, and water. For Democritus indivisible particles or atoms are fundamental to all phenomena. It is evident that the theory of Thales was a starting point for Greek abstract thought, and that his inclination to seek out principles and general laws accounts for his influence on the development both of philosophy and the sciences.

Pythagoras, on the advice of Thales, visited Egypt in the pursuit of mathematics. There is reason to believe that he also visited Babylonia. For him and his followers mathematics became a philosophy almost a religion. They had discovered (by experimenting with the monochord, the first piece of physical-laboratory apparatus, consisting of a tense harpstring with a movable bridge) the effect on the 
tone of the string of a musical instrument when the length is reduced by one half, and also that strings of like thickness and under equal tension yield harmonious tones when their lengths are related as $1: 2,2: 3,3: 4,4: 5$. The Pythagoreans drew from this the extravagant inference that the heavenly bodies would be in distance from the earth as 1,2 , $3,4,5$, etc. Much of their theory must seem to the modern mind merely fanciful and unsupported speculation. At the same time it is only just to this school of philosophers to recognize that their assumption that simple mathematical relationships govern the phenomena of nature has had an immense influence on the advance of the sciences. Whether their fanaticism for number was owing to the influence of Egyptian priests or had an Oriental origin, it gave to the Pythagoreans an enthusiasm for pure mathematics. They disregarded the bearing of their science on the practical needs of life. Old problems like squaring the circle, trisecting the angle, and doubling the cube, were now attempted in a new spirit and with fresh vigor. The first, second, and fourth books of Euclid are largely of Pythagorean origin. For solid geometry as a science we are also indebted to this sect of number-worshipers. One of them (Archytas, 428-347 B.c., a friend of Plato) was the first to apply geometry to mechanics. We see again here, as in the case of Thales, that the love of abstract thought, the pursuit of science as science, did not interfere with ultimate practical applications.

Plato (429-347 B.c.), like many other Greek philosophers, traveled extensively, visiting Asia 
Minor, Egypt, and Lower Italy, where Pythagorean influence was particularly strong. His chief interest lay in speculation. For him there were two worlds, the world of sense and the world of ideas. The senses deceive us; therefore, the philosopher should turn his back upon the world of sensible impressions, and develop the reason. In his Dialogues he outlined a course of training and study, the professed object of which was to educate a class of philosophers. (Strange to say, Plato's curriculum, planned originally for the intellectual élite, still dictates in our schools the education of millions of boys and girls whose careers do not call for a training merely of the reason.)

Over the porch of his school, the Academy at Athens, were inscribed the words, "Let no one who is unacquainted with geometry enter here." It was not because it was useful in everyday life that Plato laid such insistence on this study, but because it increased the students' powers of abstraction and trained the mind to correct and vigorous thinking. From his point of view the chief good of geometry is lost unless we can through it withdraw the mind from the particular and the material. He delighted in clearness of conception. His main scientific interest was in astronomy and mathematics. We owe to him the definition of a line as "length without breadth," and the formulation of the axiom, "Equals subtracted from equals leave equals."

Plato had an immediate influence in stimulating mathematical studies, and has been called a maker of mathematicians. Euclid, who was active at Alexandria toward the end of the fourth century B.C., was not one of Plato's immediate disciples but shared the 
great philosopher's point of view. The story is told that one of his pupils, arrived perhaps at the pons asinorum, asked, "What do I get by learning these things?" Euclid, calling his servant, said, "Give him sixpence, since he must make gain out of what he learns." Adults were also found, even among the nimble-witted Greeks, to whom abstract reasoning was not altogether congenial. This is attested by the familiar story of Ptolemy, King of Egypt, who once asked Euclid whether geometry could not be learned in some easier way than by studying the geometer's book, The Elements. To this the schoolmaster replied, "There is no royal road to geometry." For the academic intelligence abstract and abstruse mathematics are tonic and an end in themselves. As already stated, their ultimate practical value is also immense. One of Plato's associates, working under his direction, investigated the curves produced by cutting cones of different kinds in a certain plane. These curves - the ellipse, the parabola, hyperbola - play a large part in the subsequent history of astronomy and mechanics. Another Platonist made the first measurement of the earth's circumference.

Aristotle, the greatest pupil of Plato, was born at Stagira in 384 B.c. He came of a family of physicians, was trained for the medical profession, and had his attention early directed to natural phenomena. He entered the Academy at Athens about 367 B.c., and studied there till the death of Plato twenty years later. He was a diligent but, as was natural, considering the character of his early education, by no means a passive student. Plato said that Aristotle reacted against his instructor as a vigorous colt kicks 


\section{INFLUENCE OF ABSTRACT THOUGHT 21}

the mother that nourishes it. The physician's son did not accept without modification the view that the philosopher should turn his back upon the things of sense. He had been trained in the physical science of the time, and believed in the reality of concrete things. At the same time he absorbed what he found of value in his master's teachings. He thought that ${ }_{\lambda}$ science did not consist in a mere study of individual things, but that we must pass on to a formulation of general principles and then return to a study of the concrete. His was a great systematizing intellect, which has left its imprint on nearly every department of knowledge. Physical astronomy, physical geography, meteorology, physics, chemistry, geology, botany, anatomy, physiology, embryology, and zoölogy were enriched by his teaching. It was through him that logic, ethics, psychology, rhetoric, æsthetics, political science, zoölogy (especially ichthyology), first received systematic treatment. As a great modern philosopher has said, Aristotle pressed his way through the mass of things knowable, and subjected its diversity to the power of his thought. No wonder that for ages he was known as "The Philosopher," master of those who know. His purpose was to comprehend, to define, to classify the phenomena of organic and inorganic nature, to systematize the knowledge of his own time.

Twenty years' apprenticeship in the school of Plato had sharpened his logical powers and added to his stock of general ideas, but had not taught him to distrust his senses. When we say that our eyes deceive us, we really confess that we have misinterpreted the data that our sight has furnished. Properly to know 
involves the right use of the senses as well as the right use of reason. The advance of science depends on the development both of speculation and observation. Aristotle advised investigators to make sure of the facts before seeking the explanation of the facts. Where preconceived theory was at variance with observed facts, the former must of course give way. Though it has been said that while Plato was a dreamer, Aristotle was a thinker, yet it must be acknowledged in qualification that Plato often showed genuine knowledge of natural phenomena in anatomy and other departments of study, and that Aristotle was carried away at times by his own presuppositions, or failed to bring his theories to the test of observation. The Stagirite held that the velocity of falling bodies is proportional to their weight, that the function of the diaphragm is to divide. the region of the nobler from that of the animal passions, and that the brain is intended to act in opposition to the heart, the brain being formed of earthy and watery material, which brings about a cooling effect. The theory of the four elements - the hot, the cold, the moist, the dry - led to dogmatic statements with little attempt at verification. From the standpoint of modern studies it is easy to point out the mistakes of Aristotle even. Science is progressive, not infallible.

In his own time he was rather reproached for what was considered an undignified and sordid familiarity with observed facts. His critics said that having squandered his patrimony, he had served in the army, and, failing there, had become a seller of drugs. His observations on the effects of heat seem to have been drawn from the common processes of the home and 
the workshop. Even in the ripening of fruits heat appears to him to have a cooking effect. Heat distorts articles made of potters' clay after they have been hardened by cold. Again we find him describing the manufacture of potash and of steel. He is not disdainful of the study of the lower animals, but invites us to investigate all forms in the expectancy of discovering something natural and beautiful. In a similar spirit of scientific curiosity the Aristotelian work The Problems studies the principle of the lever, the rudder, the wheel and axle, the forceps, the balance, the beam, the wedge, as well as other mechanical principles.

In Aristotle, in fact, we find a mind exceptionally able to form clear ideas, and at the same time to observe the rich variety of nature. He paid homage both to the multiplicity and the uniformity of nature, the wealth of the phenomena and the simplicity of the law explaining the phenomena. Many general and abstract ideas (category, energy, entomology, essence, mean between extremes, metaphysics, meteorology, motive, natural history, principle, syllogism) have through the influence of Aristotle become the common property of educated people the world over.

Plato was a mathematician and an astronomer. A ristotle was first and foremost a biologist. His books treated the history of animals, the parts of animals, the locomotion of animals, the generation of animals, respiration, life and death, length and shortness of life, youth and old age. His psychology is, like that of the present day, a biological psychology. In his contributions to biological science is mani- 
fested his characteristic inclination to be at once abstract and concrete. His works display a knowledge of over five hundred living forms. He dissected specimens of fifty different species of animals. One might mention especially his minute knowledge of the seaurchin, of the murex (source of the famous Tyrian dye), of the chameleon, of the habits of the torpedo, the so-called fishing-frog, and nest-making fishes, as well as of the manner of reproduction of whales and certain species of sharks. One of his chief contributions to anatomy is the description of the heart and of the arrangement of the blood-vessels. A repugnance to the dissection of the human body seems to have checked to some extent his curiosity in reference to the anatomy of man, but he was acquainted with the structure of the internal ear, the passage leading from the pharynx to the middle ear, and the two outer membranes of the brain of man. Aristotle's genius did not permit him to get lost in the mere details of observed phenomena. He recognized resemblances and differences between the various species, classified animals as belonging to two large groups, distinguished whales and dolphins from fishes, recognized the family likeness of the domestic pigeon, the wood pigeon, the rock pigeon, and the turtle dove. He laid down the characteristics of the class of invertebrates to which octopus and sepia belong. Man takes a place in Aristotle's system of nature as a social animal, the highest type of the whole series of living beings, characterized by certain powers of recall, reason, deliberation. Of course it was not to be expected that Aristotle should work out a fully satisfactory classification of all the varieties of plants 
and animals known to him. Yet his purpose and method mark him as the father of natural science. $\mathrm{He}$ had the eye to observe and the mind to grasp the relationships and the import of what he observed. His attempt to classify animals according to the nature of their teeth (dentition) has been criticized as unsuccessful, but this principle of classification is still of use, and may be regarded as typical of his mind, at once careful and comprehensive.

One instance of Aristotle's combining philosophical speculation with acute observation of natural phenomena is afforded by his work on generation and development. He knew that the transmission of life deserves special study as the predominant function of the various species of plants and animals. Deformed parents may have well-formed offspring. Children may resemble grandparents rather than parents. It is only toward the close of its development that the embryo exhibits the characteristics of its parent species. Aristotle traced with some care the embryological development of the chick from the fourth day of incubation. His knowledge of the propagation of animals was, however, not sufficient to make him reject the belief in spontaneous generation from mud, sand, foam, and dew. His errors are readily comprehensible, as, for example, in attributing spontaneous generation to eels, the habits and mode of reproduction of which only recent studies have made fully known. In regard to generation, as in other scientific fields, the philosophic mind of Aristotle anticipated modern theories, and also raised general questions only to be solved by later investigation of the facts. 
Only one indication need be given of the practical results that flowed from Aristotle's scientific work. In one of his writings he has stated that the sphericity of the earth can be observed from the fact that its shadow on the moon at the time of eclipse is an arc. That it is both spherical and small in comparison with the heavenly bodies appears, moreover, from this, that stars visible in Egypt are invisible in countries farther north; while stars always above the horizon in northern countries are seen to set from countries to the south. Consequently the earth is not only spherical but also not large ; otherwise this phenomenon would not present itself on so limited a change of position on the part of the observer. "It seems, therefore, not incredible that the region about the Pillars of Hercules [Gibraltar] is connected with that of India, and that there is thus only one ocean." It is known that this passage from The Philosopher influenced Columbus in his undertaking to reach the Orient by sailing west from the coast of Spain.

We must pass over Aristotle's observation of a relationship (homology) between the arms of man, the forelegs of quadrupeds, the wings of birds, and the pectoral fins of fishes, as well as many other truths to which his genius for generalization led him.

In the field of botany Aristotle had a wide knowledge of natural phenomena, and raised general questions as to mode of propagation, nourishment, relation of plants to animals, etc. His pupil and lifelong friend, and successor as leader of the Peripatetic school of philosophy, Theophrastus, combined a.knowledge of mathematics, astronomy, botany, and 


\section{INFLUENCE OF ABSTRACT THOUGHT 27}

mineralogy. His History of Plants describes about five hundred species. At the same time he treats the general principles of botany, the distribution of plants, the nourishment of the plant through leaf as well as root, the sexuality of date palm and terebinth. He lays great stress on the uses of plants. His classification of plants is inferior to Aristotle's classification of animals. His views in reference to spontaneous generation are more guarded than those of his master. His work On Stones is dominated by the practical rather than the generalizing spirit. It is evidently inspired by a knowledge of mines, such as the celebrated Laurium, from which Athens drew its supply of silver, and the wealth from which enabled the Athenians to develop a sea-power that overmatched that of the Persians. Even to-day enough remains of the galleries, shafts, scoria, mine-lamps, and other utensils to give a clear idea of this scene of ancient industry. Theophrastus considered the medicinal uses of minerals as well as of plants.

We have failed to mention Hippocrates (460-370 B.c.), the Father of Medicine, in whom is found an intimate union of practical science and speculative philosophy. We must also pass over such later Greek scientists as Aristarchus and Hipparchus who confuted the theories of Pythagoras and Plato in reference to the relative distances of the heavenly bodies from the earth. Archimedes of Syracuse demands, however, particular consideration. He lived in the third century B.C., and has been called the greatest mathematician of antiquity. In him we find the devotion to the abstract that marked the Greek intelligence. He went so far as to say that every kind of 
art is ignoble if connected with daily needs. His interest lay in abstruse mathematical problems. His special pride was in having determined the relative dimensions of the sphere and the enclosing cylinder. He worked out the principle of the lever. "Give me," he said, "a place on which to stand and I will move the earth." He approximated more closely than the Egyptians the solution of the problem of the relation between the area of a circle and the radius. His work had practical value in spite of himself. At the request of his friend the King of Sicily, he applied his ingenuity to discover whether a certain crown were pure gold or alloyed with silver, and he hit upon a method which has found many applications in the industries. His name is associated with the endless screw. In fact, his practical contrivances won such repute that it is not easy to separate the historical facts from the legends that enshroud his name. He aided in the defense of his native city against the Romans in 212 B.C., and devised warengines with which to repel the besiegers. After the enemy had entered the city, says tradition, he stood absorbed in a mathematical problem which he had diagrammed on the sand. As a rude Roman soldier approached, Archimedes cried, "Don't spoil my circles," and was instantly killed. The victorious general, however, buried him with honor, and on the tomb of the mathematician caused to be inscribed the sphere with its enclosing cylinder. The triumphs of Greek abstract thought teach the lesson that practical men should pay homage to speculation even when they fail to comprehend a fraction of it. 


\section{INFLUENCE OF ABSTRACT THOUGHT 29}

\section{REFERENCES}

Aristotle, Historia Animalium ; translated by D'A. W. Thompson. (Vol. Iv of the Works of Aristotle Translated into English. Oxford: Clarendon Press.)

A. B. Buckley (Mrs. Buckley Fisher), A Short History of Natural Science.

G. H. Lewes, Aristotle; A Chapter in the History of Science.

T. E. Lones, Aristotle's Researches in Natural Science.

D'A. W. Thompson, On Aristotle as a Biologist.

William Whewell, History of the Inductive Sciences.

Alfred Weber, History of Philosophy. 


\section{CHAPTER III}

\section{SCIENTIFIC THEORY SUBORDINATED TO APPLICATION - ROME : VITRUVIUS}

VITRUvius was a cultured engineer and architect. He was employed in the service of the Roman State at the time of Augustus, shortly before the beginning of the Christian era. He planned basilicas and aqueducts, and designed powerful war-engines capable of hurling rocks weighing three or four hundred pounds. He knew the arts and the sciences, held lofty ideals of professional conduct and dignity, and was a diligent student of Greek philosophy.

We know of him chiefly from his ten short books on Architecture (De Architectura, Libri Decem), in which he touches upon much of the learning of his time. Architecture for Vitruvius is a science arising out of many other sciences. Practice and theory are its parents. The merely practical man loses much by not knowing the background of his activities; the mere theorist fails by mistaking the shadow for the substance. Vitruvius in the theoretical and historical parts of his book draws largely on Greek writers ; but in the parts bearing on practice he sets forth, with considerable shrewdness, the outcome of years of thoughtful professional experience. One cannot read his pages without feeling that he is more at home in the concrete than in the abstract and speculative, in describing a catapult than in explaining a scientific theory or a philosophy. $\mathrm{He}$ 
was not a Plato or an Archimedes, but an efficient officer of State, conscious of indebtedness to the great scientists and philosophers. With a just sense of his limitations he undertook to write, not as a literary man, but as an architect. His education had been mainly professional, but, the whole circle of learning being one harmonious system, he had been drawn to many branches of knowledge in so far as they were related to his calling.

In the judgment of Vitruvius an architect should be a good writer, able to give a lucid explanation of his plans, a skillful draftsman, versed in geometry and optics, expert at figures, acquainted with history, informed in the principles of physics and of ethics, knowing something of music (tones and acoustics), not ignorant of law, or of hygiene, or of the motions, laws, and relations to each other of the heavenly bodies. For, since architecture " is founded upon and adorned with so many different sciences, I am of opinion that those who have not, from their early youth, gradually climbed up to the summit, cannot without presumption, call themselves masters of it."

Vitruvius was far from sharing the view of Archimedes that art which was connected with the satisfaction of daily needs was necessarily ignoble and vulgar. On the contrary, his interest centered in the practical; and he was mainly, concerned with scientific theory by reason of its application in the arts. Geometry helped him plan a staircase; a knowledge of tones was necessary in discharging catapults; law dealt with boundary-lines, sewage-disposal, and contracts; hygiene enabled the architect to show a Hippocratic wisdom in the choice of building-sites with 
due reference to airs and waters. Vitruvius had the Roman practical and regulative genius, not the abstract and speculative genius of Athens.

The second book begins with an account of different philosophical views concerning the origin of matter, and a discussion of the earliest dwellings of man. Its real theme, however, is building-material - brick, sand, lime, stone, concrete, marble, stucco, timber, pozzolano. In reference to the last (volcanic ash combined with lime and rubble to form a cement) Vitruvius writes in a way that indicates a discriminating knowledge of geological formations. Likewise his discussion of the influence of the Apennines on the rainfall, and, consequently, on the timber of the firs on the east and west of the range, shows a grasp of meteorological principles. His real power to generalize is shown in connection with his specialty, in his treatment of the sources of building-material, rather than in his consideration of the origin of matter.

Similarly the fifth book begins with a discussion of the theories of Pythagoras, but its real topic is public buildings - fora, basilicas, theaters, baths, palæstras, harbors, and quays. In the theaters bronze vases of various sizes, arranged according to Pythagorean musical principles, were to be used in the auditorium to reinforce the voice of the actor. (This recommendation was misunderstood centuries later, when Vitruvius was considered of great authority, and led to the futile practice of placing earthenware jars beneath the floors of church choirs.) According to our author, "The voice arises from flowing breath, sensible to the hearing through its percussion on 
the air." It is compared to the wavelets produced by a stone dropped in water, only that in the case of sound the waves are not confined to one plane. This generalization concerning the nature of sound was probably not original, however; it may have been suggested to Vitruvius by one of the Aristotelian writings.

The seventh book treats of interior decoration mosaic floors, gypsum mouldings, wall painting, white lead, red lead, verdigris, mercury (which may be used to recover gold from worn-out pieces of embroidery), encaustic painting with hot wax, colors (black, blue, genuine and imitation murex purple). The eighth book deals with water and with hydraulic engineering, hot springs, mineral waters, leveling instruments, construction of aqueducts, lead and clay piping. Vitruvius was not ignorant of the fact that water seeks its own level, and he even argued that air must have weight in order to account for the rise of water in pumps. In his time it was more economical to convey the hard water by aqueducts than by such pipes as could then be constructed. The ninth book undertakes to rehearse the elements of geometry and astronomy - the signs of the zodiac, the sun, moon, planets, the phases of the moon, the mathematical divisions of the gnomon, the use of the sundial, etc. One feels in reading Vitruvius that his purpose was to turn to practical account what he had gained from the study of the sciences; and, at the same time, one is convinced that his applications tend to react on theoretical knowledge, and lead to new insights through the suggestion of new problems.

The tenth book of the so-called De Architectura 
is concerned with machinery - windmills, windlasses, axles, pulleys, cranes, pumps, fire-engines, revolving spiral tubes for raising water, wheels for irrigation worked by water-power, wheels to register distance traveled by land or water, scaling-ladders, battering-rams, tortoises, catapults, scorpions, and ballistæ. On the subject of war-engines Vitruvius speaks with special authority, as he had served, probably as military engineer, under Julius Cæsar in 46 B.C., and had been appointed superintendent of ballistæ and other military engines in the time of Augustus. It was to the divine Emperor that his book was dedicated as a protest against the administration of Roman public works. In its pages we see reflected the life of a nation employed in conquering and ruling the world, with a genius more distinguished for practical achievement than for theory and speculation. Its author is truly representative of Roman culture, for nearly everything that Rome had of a scientific and intellectual sort it drew from Greece, and it selected that part of Greek wisdom that ministered to the daily needs of the times. In his work on architecture, Vitruvius shows himself a diligent and devoted student of the sciences in order that he may turn them to account in his own department of technology.

If you glance at the study of mathematics, astronomy, and medicine among the Romans prior to the time of Greek influence, you find that next to nothing had been accomplished. Their method of field measurement was far less developed than the ancient Egyptian geometry, and even for it (as well as for their system of numerals) they were indebted to 
the Etruscans. The history of astronomy has nothing to record of scientific accomplishment on the part of the Romans. They reckoned time by months, and in the earlier period kept a rude tally of the years by driving nails into a statue of Janus, the ancient sun-god. As we shall see, they were unable to regulate the calendar. Again, so far were they from contributing to the development of medicine that they had no physicians for the six hundred years preceding the coming of Greek science. A medical slave acted as overseer of the family health, and disease was combated in primitive fashion by prayers and offerings to various gods, who were supposed to furnish general health or to influence the functions of the different parts of the body. So rude was the native culture of the Romans that it is doubtful whether they had any schools before the advent of Greek learning. The girls were trained by their mothers, the boys either by their fathers or by some master to whom they were apprenticed.

The Greeks were conquered by the Romans in 146 B.c., but before that time Roman life and institutions had been touched by Hellenic culture. Cato the Censor (who died in 149 B.c.) and other conservatives tried in vain to resist the invasion of Greek science, philosophy, and refinement. After the conquest of Greece the master became pupil, and the conqueror was taken captive. The Romans, however, never rose to preëminence in science or the fine arts. A further development in technology corresponded more closely to their national needs, and in this field they came undoubtedly to surpass the Greeks. Bridges, ships, military roads, war-engines, 
aqueducts, public buildings, organization of the State and the army, the formulation of legal procedure, the enactment and codification of laws, were necessary to secure and maintain the Empire. The use in building construction of a knowledge of the right-angled triangle as well as other matters known to the Egyptians and Babylonians, and Archimedes' method of determining specific gravity were of peculiar interest to the practical Romans.

Julius Cæsar, 102-44 B.c., instituted a reform of the calendar. This was very much needed, as the Romans were eighty-five days out of their reckoning, and the date for the spring equinox, instead of coming at the proper time, was falling in the middle of winter. An Alexandrian astronomer (Sosigenes) assisted in establishing the new (Julian) calendar. The principle followed was based on ancient Egyptian practice. Among the 365 days of the year was to be inserted, or intercalated, every fourth year an extra day. This the Romans did by giving to two days in leap-year the same name; thus the sixth day before the first of March was repeated, and leapyear was known as a bissextile year. Cæsar, trained himself in the Greek learning and known to his contemporaries as a writer on mathematios and astronomy, also planned a survey of the Empire, which was finally carried into execution by Augustus.

There is evidence that the need of technically trained men became more and more pressing as the Empire developed. At first there were no special teachers or schools. Later we find mention of teachers of architecture and mechanics. Then the State came to provide classrooms for technical instruction 
and to pay the salaries of the teachers. Finally, in the fourth century A.D., further measures were adopted by the State. The Emperor Constantine writes to one of his officials: "We need as many engineers as possible. Since the supply is small, induce to begin this study youths of about eighteen years of age who are already acquainted with the sciences required in a general education. Relieve their parents from the payment of taxes, and furnish the students with ample means."

Pliny the Elder (23-79 A.D.), in the encyclopedic work which he compiled under the title Natural History, drew freely on hundreds of Greek and Latin authors for his facts and fables. In the selection that he made from his sources can be traced, as in the work of Vitruvius and other Latin writers, the tendency to make the sciences subservient to the arts. For example, the one thousand species of plants of which he makes mention are considered from the medicinal or from the economic point of view. It was largely in the interest of their practical uses that the Roman regarded both plants and animals; his chief motive was not a disinterested love of truth. Pliny thought that each plant had its special virtue, and much of his botany is applied botany. So comprehensive a work as the Natural History was sure to contain interesting anticipations of modern science. Pliny held that the earth hovers in the heavens upheld by the air, that its sphericity is proved by the fact that the mast of a ship approaching the land is visible before the hull comes in sight. He also taught that there are inhabitants on the other side of the earth (antipodes), that at the time of the winter 
solstice the polar night must last for twenty-four hours, and that the moon plays a part in the production of the tides. Nevertheless, the whole book is permeated by the idea that the purpose of nature is to minister to the needs of man.

It further marks the practical spirit among the Romans that a work on agriculture by a Carthaginian (Mago) was translated by order of the Senate. Cato (234-149 B.c.), so characteristically Roman in his genius, wrote (De Re Rustica) concerning grains and the cultivation of fruits. Columella wrote treatises on agriculture and forestry. Among the technical writings of Varro besides the book on agriculture, which is extant, are numbered works on law, mensuration, and naval tactics.

It was but natural that at the time of the Roman Empire there should be great advances in medical science. A Roman's interest in a science was keen when it could be proved to have immediate bearing on practical life. The greatest physician of the time, however, was a Greek. Galen (131-201 A.D.), who counted himself a disciple of Hippocrates, began to practice at Rome at the age of thirty-three. He was the only experimental physiologist before the time of Harvey. He studied the vocal apparatus in the larynx, and understood the contraction and relaxation of the muscles, and, to a considerable extent, the motion of the blood through the heart, lungs, and other parts of the body. He was a vivisector, made sections of the brain in order to determine the functions of its parts, and severed the gustatory, optic, and auditory nerves with a similar end in view. His dissections were confined to the lower animals. Yet 
his works on human anatomy and physiology were authoritative for the subsequent thirteen centuries. It is difficult to say how much of the work and credit of this practical scientist is to be given to the race from which he sprang and how much to the social environment of his professional career. (In the ruins of Pompeii, destroyed in 79 A.D., have been recovered some two hundred kinds of surgical instrument, and in the later Empire certain departments of surgery developed to a degree not surpassed till the sixteenth century.) If it is too much to say that the Roman environment is responsible for Galen's achievements, we can at least say that it was characteristic of the Roman people to welcome such science as his, capable of demonstrating its utility.

Dioscorides was also a Greek who, long resident at Rome, applied his science in practice. He knew six hundred different plants, one hundred more than Theophrastus. The latter laid much stress, as we have seen in the preceding chapter, on the medicinal properties of plants, but in this respect he was outdone by Dioscorides (as well as by Pliny). Theophrastus was the founder of the science of botany, Dioscorides the founder of materia medica.

Quintilian, born in Spain, spent the greater part of his life as a teacher of rhetoric in Rome. He valued the sciences, not on their own account, but as they might subserve the purposes of the orator. Music, astronomy, logic, and even theology, might be exploited as aids to public speech. In the time of Quintilian (first century A.D.), as in our own, oratory was considered one of the great factors in a young man's 
success; mock debating contests were frequent, and the periods of the future orators reverberated among the seven hills of Rome. To him our schools are also indebted for the method of teaching foreign languages by declensions, conjugations, vocabularies, formal rhetoric and annotations. He considered ethics the most valuable part of philosophy.

In fact, it would not be pressing our argument unduly to say that, so far as the minds of the Romans turned to speculation, it was the tendency to practical philosophy - Epicureanism or Stoicism - that was most characteristic. This was true even of $\mathrm{Lu}$ cretius (98-55 B.c.), author of the noble poem concerning the Nature of Things (De Rerum Natura). In this work he writes under the inspiration of Greek philosophy. His model was a poem by Empedocles on Nature, the grand hexameters of which had fascinated the Roman poet. The distinctive feature of the work of Lucretius is the purpose, ethical rather than speculative, to curb the ambition, passion, luxury of those hard pagan times, and likewise to free the souls of his countrymen from the fear of the gods and the fear of death, and to replace superstition by peace of mind and purity of heart.

From the work on Physical Science (Quaestionum Naturalium, Libri Septem) of Seneca, the tutor of Nero, we learn that the Romans made use of globes filled with water as magnifiers, employed hothouses in their highly developed horticulture, and observed the refraction of colors by the prism. At the same time the book contains interesting conjectures in reference to the relation of earthquakes and volcanoes, and to the fact that comets travel in fixed 
orbits. In the main, however, this work is an attempt to find a basis for ethics in natural phenomena. Seneca was a Stoic, as Lucretius was an Epicurean, moralist.

When we glance back at the culture, or cultures, of the great peoples of antiquity, Egyptian, Babylonian, Greek, and Roman, that which had its center on the banks of the Tiber offers the closest analogy to our own. Among English-speaking peoples as among the Romans there is noticeable a certain contempt for scientific studies strangely mingled with an inclination to exploit all theory in the interest of immediate application. An English author, writing in 1834, remarks that the Romans, eminent in war, in polite literature, and civil policy, showed at all times a remarkable indisposition to the pursuit of mathematical and physical science. Geometry and astronomy, so highly esteemed by the Greeks, were not merely disregarded by the Italians, but even considered beneath the attention of a man of good birth and liberal education; they were imagined to partake of a mechanical, and therefore servile, character. "The results were seen to be made use of by the mechanical artist, and the abstract principles were therefore supposed to be, as it were, contaminated by his touch. This unfortunate peculiarity in the taste of his countrymen is remarked by Cicero. And it may not be irrelevant to inquire, whether similar prejudices do not prevail to some extent even among ourselves." To Americans also must be attributed an impatience of theory as theory, and a predominant interest in the applications of science. 


\section{THE HISTORY OF SCIENCE}

\section{REFERENCES}

Lucretius, The Nature of Things; translated by H. A. J. Munro.

Pliny, Natural History; translated by Philemon Holland.

Professor Baden Powell, History of Natural Philosophy.

Seneca, Physcial Science; translated by John Clarke.

Vitruvius, Architecture; translated by Joseph Gwilt, 1826.

Vitruvius, Architecture; translated by Professor M. H. Morgan, 1914. 


\section{CHAPTER IV}

THE CONTINUITY OF SCIENCE - THE MEDIEVAL CHURCH AND THE ARABS

LEARNING has very often and very aptly been compared to a torch passed from hand to hand. By the written sign or spoken word it is transmitted from one person to another. Very little advance in culture could be made even by the greatest man of genius if he were dependent, for what knowledge he might acquire, merely on his own personal observation. Indeed, it might be said that exceptional mental ability involves a power to absorb the ideas of others, and even that the most original people are those who are able to borrow the most freely.

In recalling the lives of certain great men we may at first be inclined to doubt this truth. How shall we account for the part played in the progress of civilization by the rustic Burns, the village-bred Shakespeare, or by Lincoln the frontiersman? When, however, we scrutinize the case of any one of these, we discover, of course, exceptional natural endowment, susceptibility to mental influence, remarkable powers of acquisition, but no ability to produce anything absolutely original. In the case of Lincoln, for example, we find that in his youth he was as distinguished by diligence in study as by physical stature and prowess. After he withdrew from school, he read, wrote, and ciphered (in the intervals of manual work) almost incessantly. He read 
everything he could lay hands on. He copied out what most appealed to him. A few books he read and re-read till he had almost memorized them. What constituted his library? The Bible, AEsop's Fables, Robinson Crusoe, The Pilgrim's Progress, a Life of Washington, a History of the United States. These established for him a vital relation with the past, and laid the foundations of a democratic culture; not the culture of a Chesterfield, to be sure, but something immeasurably better, and none the less good for being almost universally accessible. Lincoln developed his logical powers conning the dictionary. Long before he undertook the regular study of the law, he spent long hours poring over the revised statutes of the State in which he was living. From a book he mastered with a purpose the principles of grammar. In the same spirit he learned surveying, also by means of a book. There is no need to ignore any of the influences that told toward the development of this great statesman, the greatest of English-speaking orators, but it is evident that remote as was his habitation from all the famous centers of learning he was, nevertheless, early immersed in the current of the world's best thought.

Similarly, in the history of science, every great thinker has his intellectual pedigree. Aristotle was the pupil of Plato, Plato was the disciple of Socrates, and the latter's intellectual genealogy in turn can readily be traced to Thales, and beyond - to Egyptian priests and Babylonian astronomers.

The city of Alexandria, founded by the pupil of Aristotle in 332 B.C., succeeded Athens as the center 


\section{THE CONTINUITY OF SCIENCE}

of Greek culture. On the death of Alexander the Great, Egypt was ruled by one of his generals, Ptolemy, who assumed the title of king. This monarch, though often engaged in war, found time to encourage learning, and drew to his capital scholars and philosophers from Greece and other countries. He wrote himself a history of Alexander's campaigns, and instituted the famous library of Alexandria. This was greatly developed (and supplemented with schools of science and an observatory) by his son Ptolemy Philadelphus, a prince distinguished by his zeal in promoting the good of the human species. He collected vast numbers of manuscripts, had strange animals brought from distant lands to Alexandria, and otherwise promoted scientific research. This movement was continued under Ptolemy III (246-221 B.c.).

Something has already been said of the early astronomers and mathematicians of Alexandria. The scientific movement of the later Alexandrian period found its consummation in the geographer, astronomer, and mathematician Claudius Ptolemy (not to be confused with the rulers of that name). He was most active 127-151 A.D., and is best known by his work the Syntaxis, which summarized what was known in astronomy at that time. Ptolemy drew up a catalogue of 1080 stars based on the earlier work of Hipparchus. He followed that astronomer in teaching that the earth is the center of the movement of the heavenly bodies, and this geocentric system of the heavens became known as the Ptolemaic system of astronomy. To Hipparchus and Ptolemy we owe also the beginnings of the science 
of trigonometry. The Syntaxis sets forth his method of drawing up a table of chords. For example, the side of a hexagon inscribed in a circle is equal to the radius, and is the chord of $60^{\circ}$, or of the sixth part of the circle. The radius is divided into sixty equal parts, and these again divided and subdivided sexagesimally. The smaller divisions and the sub. divisions are known as prime minute parts and second minute parts (partes minutce primoe and partes minutce secundoe), whence our terms "minute" and "second." The sexagesimal method of dividing the circle and its parts was, as we have seen in the first chapter, of Babylonian origin.

Ptolemy was the last of the great Greek astronomers. In the fourth century and at the beginning of the fifth, Theon and his illustrious daughter $\mathrm{Hy}$ patia commented on and taught the astronomy of Ptolemy. In the Greek schools of philosophy Plato's doctrine of the supreme reality of the invisible world was harmonized for a time with Christian mysticism, but these schools were suppressed at the beginning of the sixth century. The extinction of scientific and of all other learning seemed imminent.

What were the causes of this threatened break in the historical continuity of science? They were too many and too varied to admit of adequate statement here. From the latter part of the fourth century the Roman Empire had been overrun by the Visigoths, the Vandals, the Huns, the Ostrogoths, the Lombards, and other barbarians. Even before these incursions learning had suffered under the calamity of war. In the time of Julius Cæsar the larger of the famous libraries of Alexandria, containing, it is com- 


\section{THE CONTINUITY OF SCIENCE}

puted, some 490,000 rolls, caught fire from ships burning in the harbor, and perished. This alone involved an incalculable setback to the march of scientific thought.

- Another influence tending to check the advance of the sciences was the clash between Christian and Pagan ideals. To many of the bishops of the Church the aims and pursuits of science seemed vain and trivial when compared with the preservation of purity of character or the assurance of eternal felicity. Many were convinced that the end of the world was at hand, and strove to fix their thoughts solely on the world to come. Their austere disregard of this life found some support in a noble teaching of the Stoic philosophy that death itself is no evil to the just man. The early Christian teachers held that the body should be mortified if it interfered with spiritual welfare. Disease is a punishment, or a discipline to be patiently borne. One should choose physical uncleanliness rather than run any risk of moral contamination. It is not impossible for enlightened people at the present time to assume a tolerant attitude toward the worldly Greeks or the other-worldly Christians. At that time, however, mutual antipathy was intense. The long and cruel war between science and Christian theology had begun.

Not all the Christian bishops, to be sure, took a hostile view of Greek learning. Some regarded the great philosophers as the allies of the Church. Some held that churchmen should study the wisdom of the Greeks in order the better to refute them. Others held that the investigation of truth was no longer necessary after mankind had received the revelation 
of the gospel. One of the ablest of the Church Fathers regretted his early education and said that it would have been better for him if he had never heard of Democritus. The Christian writer Lactantius asked shrewdly whence atoms came, and what proof there was of their existence. He also allowed himself to ridicule the idea of the antipodes, a topsy-turvy world of unimaginable disorder. In 389 A.D. one of the libraries at Alexandria was destroyed and its books were pillaged by the Christians. In 415 Hypatia, Greek philosopher and mathematician, was murdered by a Christian mob. In 642 the Arabs having pushed their conquest into northern Africa gained possession of Alexandria. The cause of learning seemed finally and irrecoverably lost.

The Arab conquerors, however, showed themselves singularly hospitable to the culture of the nations over which they had gained control. Since the time of Alexander there had been many Greek settlers in the larger cities of Syria and Persia, and here learning had been maintained in the schools of the Jews and of a sect of Christians (Nestorians), who were particularly active as educators from the fifth century to the eleventh. The principal Greek works on science had been translated into Syrian. Hindu arithmetic and astronomy had found their way into Persia. By the ninth century all these sources of scientific knowledge had been appropriated by the Arabs. Some fanatics among them, to be sure, held that one book, the Koran, was of itself sufficient to insure the well-being of the whole human race, but happily a more enlightened view prevailed.

In the time of Harun Al-Rashid ( 800 A.D.), and 
his son, the Caliphate of Bagdad was the center of Arab science. Mathematics and astronomy were especially cultivated; an observatory was established; and the work of translation was systematically carried on by a sort of institute of translators, who rendered the writings of Aristotle, Hippocrates, Galen, Euclid, Ptolemy, and other Greek scientists, into Arar bic. The names of the great Arab astronomers and mathematicians are not popularly known to us; their influence is greater than their fame. One of them describes the method pursued by him in the ninth century in taking measure of the circumference of the earth. A second developed a trigonometry of sines to replace the Ptolemaic trigonometry of chords. A third made use of the so-called Arabic (really Hindu) system of numerals, and wrote the first work on Algebra under that name. In this the writer did not aim at the mental discipline of students, but sought to confine himself to what is easiest and most useful in calculation, "such as men constantly require in cases of inheritance, legacies, partition, lawsuits, and trade, and in all their dealings with one another, or where the measuring of lands, the digging of canals, geometrical computation, and other objects of various sorts and kinds are concerned."

In the following centuries Arab institutions of higher learning were widely distributed and the floodtide of Arab science was borne farther west. At Cairo about the close of the tenth century the first accurate records of eclipses were made, and tables were constructed of the motions of the sun, moon, and planets. Here as elsewhere the Arabs displayed ingenuity in the making of scientific apparatus, celes- 
tial globes, sextants of large size, quadrants of various sorts, and contrivances from which in the course of time were developed modern surveying instruments for measuring horizontal and vertical angles. Before the end of the eleventh century an Arab born at Cordova, the capital of Moorish Spain, constructed the Toletan Tables. These were followed in 1252 by the publication of the Alphonsine Tables, an event which astronomers regard as marking the dawn of European science.

Physics and chemistry, as well as mathematics and astronomy, owe much in their development to the Arabs. An Arabian scientist of the eleventh century studied the phenomena of the reflection and refraction of light, explained the causes of morning and evening twilight, understood the magnifying power of lenses and the anatomy of the human eye. Our use of the terms retina, cornea, and vitreous humor may be traced to the translation of his work on optics. The Arabs also made fair approximations to the correct specific weights of gold, copper, mercury, and lead. Their alchemy was closely associated with metallurgy, the making of alloys and amalgams, and the handicrafts of the goldsmiths and silversmiths. The alchemists sought to discover processes whereby one metal might be transmuted into another. Sulphur affected the color and substance. Mercury was supposed to play an important part in metal transmutations. They thought, for example, that tin contained more mercury than lead, and that the baser, more unhealthy metal might be converted into the nobler and more healthy by the addition of mercury. They even sought for a substance that might effect 
all transmutations, and be for mankind a cure for all ailments, even that of growing old. The writings that have been attributed to Geber show the advances that chemistry made through the experiments of the Arabs. They produced sulphuric and nitric acids, and aqua regia, able to dissolve gold, the king of metals. They could make use of wet methods, and form metallic salts such as silver nitrate. Laboratory processes like distilling, filtering, crystallization, sublimation, became known to the Europeans through them. They obtained potash from wine lees, soda from sea-plants, and from quicksilver the mercuric oxide which played so interesting a part in the later history of chemistry.

Much of the science lore of the Arabs arose from their extensive trade, and in the practice of medicine. They introduced sugar-cane into Europe, improved the methods of manufacturing paper, discovered a method of obtaining alcohol, knew the uses of gypsum and of white arsenic, were expert in pharmacy and learned in materia medica. They are sometimes credited with introducing to the West the knowledge of the mariner's compass and of gunpowder.

Avicenna (980-1037), the Arab physician, not only wrote a large work on medicine (the Canon) based on the lore of Galen, which was used as a textbook for centuries in the universities of Europe, but wrote commentaries on all the works of Aristotle. For Averroës (1126-1198), the Arab physician and philosopher, was reserved the title "The Commentator," due to his devotion to the works of the Greek biologist and philosopher. It was through the com- 
mentaries of Averroës that Aristotelian science became known in Europe during the Middle Ages. In his view Aristotle was the founder and perfecter of science; yet he showed an independent knowledge of physics and chemistry, and wrote on astronomy and medicine as well as philosophy. He set forth the facts in reference to natural phenomena purely in the interests of the truth. He could not conceive of anything being created from nothing. At the same time he taught that God is the essence, the eternal cause, of progress. It is in humanity that intellect most clearly reveals itself, but there is a transcendent intellect beyond, union with which is the highest bliss of the individual soul. With the death of the Commentator the culture of liberal science among the Arabs came to an end, but his influence (and through him that of Aristotle) was perpetuated in all the western centers of education.

The preservation of the ancient learning had not, however, depended solely on the Arabs. At the beginning of the sixth century, before the taking of Alexandria by the followers of Mohammed, St. Benedict had founded the monastery of Monte Cassino in Italy. Here was begun the copying of manuscripts, and the preparation of compendiums treating of grammar, dialectic, rhetoric, arithmetic, astronomy, music, and geometry.) These were based on ancient Roman writings. Works like Pliny's Natural History, the encyclopedia of the Middle Ages, had survived all the wars by which Rome had been devastated. Learning, which in Rome's darkest days had found refuge in Britain and Ireland, returned book in hand. Charlemagne (800) called Alcuin from 
York to instruct princes and nobles at the Frankish court. At this same palace school half a century later the Irishman Scotus Erigena exhibited his learning, wit, and logical acumen. In the tenth century Gerbert (Pope Sylvester II) learned mathematics at Arab schools in Spain. The translation of Arab works on science into the Latin language, freer intercourse of European peoples with the East through war and trade, economic prosperity, the liberation of serfs and the development of a well-to-do middle class, the voyages of Marco Polo to the Orient, the founding of universities, the encouragement of learning by the Emperor Frederick II, the study of logic by the schoolmen, were all indicative of a new era in the history of scientific thought.

The learned Dominican Albertus Magnus (11931280) was a careful student of Aristotle as well as of his Arabian commentators. In his many books on natural history he of course pays great deference to the Philosopher, but he is not devoid of original observation. As the official visitor of his order he had traveled through the greater part of Germany on foot, and with a keen eye for natural phenomena was able to enrich botany and zoölogy by much accurate information. His intimacy with the details of natural history made him suspected by the ignorant of the practice of magical arts.

His pupil and disciple Thomas Aquinas (12271274) was the philosopher and recognized champion of the Christian Church. In 1879 Pope Leo XIII, while proclaiming that every wise saying, every useful discovery, by whomsoever it may be wrought, should be welcomed with a willing and grateful 
mind, exhorted the leaders of the Roman Catholic Church to restore the golden wisdom of St. Thomas and to propagate it as widely as possible for the good of society and the advancement of all the sciences. Certainly the genius of St. Thomas Aquinas seems comprehensive enough to embrace all science as well as all philosophy from the Christian point of view. According to him there are two sources of knowledge, reason and revelation. These are not irreconcilably opposed. The Greek philosophers speak with the voice of reason. It is the duty of theology to bring all knowledge into harmony with the truths of revelation imparted by God for the salvation of the human race. Averroës is in error when he argues the impossibility of something being created from nothing, and again when he implies that the individual intellect becomes merged in a transcendental intellect; for such teaching would be the contrary of what has been revealed in reference to the creation of the world and the immortality of the individual soul. In the accompanying illustration we see St. Thomas inspired by Christ in glory, guided by Moses, St. Peter, and the Evangelists, and instructed by Aristotle and Plato. $\mathrm{He}$ has overcome the heathen philosopher Averroës, who lies below discomfited.

The English Franciscan Roger Bacon (12141294) deserves to be mentioned with the two great Dominicans. He was acquainted with the works of the Greek and Arabian scientists. He transmitted in a treatise that fell under the eye of Columbus the view of Aristotle in reference to the proximity of another continent on the other side of the Atlantic; he anticipated the principle on which the telescope was 


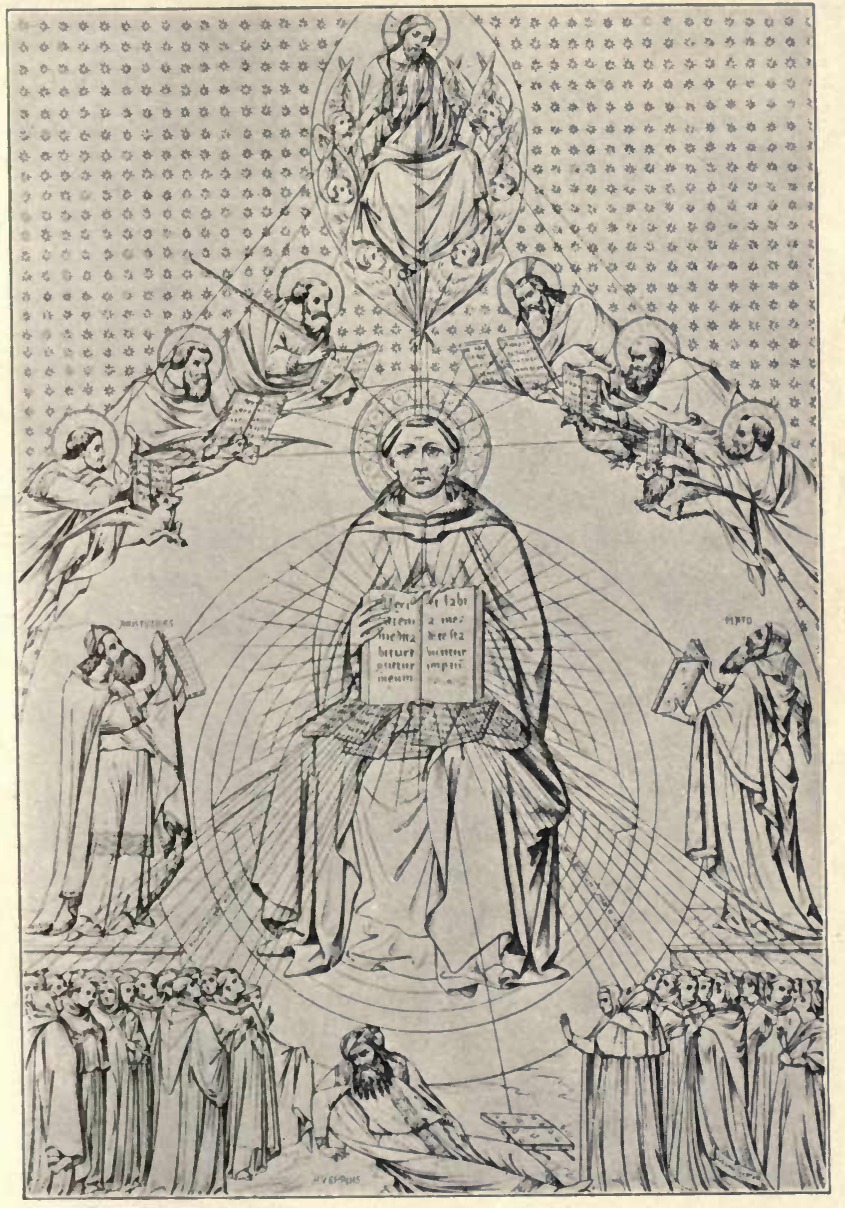

ST. THOMAS AQUINAS OVERCOMING AVERROES 

afterwards constructed; he advocated basing natural science on experience and careful observation rather than on a process of reasoning. Roger Bacon's writings are characterized by a philosophical breadth of view. To his mind the earth is only an insignificant dot in the center of the vast heavens.

In the centuries that followed the death of Bacon the relation of this planet to the heavenly bodies was made an object of study by a succession of scientists who like him were versed in the achievements of preceding ages. Peurbach (1423-1461), author of New Theories of the Planets, developed the trigonometry of the Arabians, but died before fulfilling his plan to give Europe an epitome of the astronomy of Ptolemy. His pupil, Regiomontanus, however, more than made good the intentions of his master. The work of Peurbach had as commentator the first teacher in astronomy of Copernicus (1473-1543). Later Copernicus spent nine years in Italy, studying at the universities and acquainting himself with Ptolemaic and other ancient views concerning the motions of the planets. He came to see that the apparent revolution of the heavenly bodies about the earth from east to west is really owing to the revolution of the earth on its axis from west to east. This view was so contrary to prevailing beliefs that Copernicus refused to publish his theory for thirty-six years. A copy of his book, teaching that our earth is not the center of the universe, was brought to him on his deathbed, but he never opened it.

Momentous as was this discovery, setting aside the geocentric system which had held captive the best minds for fourteen slow centuries and substituting the 


\section{THE HISTORY OF SCIENCE}

heliocentric, it was but a link in the chain of successes in astronomy to which Tycho Brahe, Kepler, Galileo, Newton, and their followers contributed.

\section{REFERENCES}

The Catholic Encyclopedia.

J. L. E. Dreyer, History of the Planetary Systems.

Encyclopadia Britannica. Arabian Philosophy; Roger Bacon. W. J. Townsend, The Great Schoolmen of the Middle Ages.

R. B. Vaughan, St. Thomas of Aquin; his Life and Labours. Andrew D. White, $A$ History of the Warfare of Science with Theology in Christendom. 


\section{CHAPTER V}

THE CLASSIFICATION OF THE SCIENCES FRANCIS BACON

THE preceding chapter has shown that there is a continuity in the development of single sciences. The astronomy, or the chemistry, or the mathematics, of one period depends so directly on the respective science of the foregoing period, that one feels justified in using the term "growth," or "evolution," to describe their progress. Now a vital relationship can be observed not only among different stages of the same science, but also among the different sciences. Physics, astronomy, and chemistry have much in common; geometry, trigonometry, arithmetic, and algebra are called "branches" of mathematics; zoology and botany are biological sciences, as having to do with living species. In the century following the death of Copernicus, two great scientists, Bacon and Descartes, compared all knowledge to a tree, of which the separate sciences are branches. They thought of all knowledge as a living organism with an interconnection or continuity of parts, and a capability of growth.

By the beginning of the seventeenth century the sciences were so considerable that in the interest of further progress a comprehensive view of the tree of knowledge, a survey of the field of learning, was needed. The task of making this survey was undertaken by Francis Bacon, Lord Verulain (1561-1626). 
His classification of human knowledge was celebrated, and very influential in the progress of science. He kept one clear purpose in view, namely, the control of nature by man. He wished to take stock of what had already been accomplished, to supply deficiencies, and to enlarge the bounds of human empire. He was acutely conscious that this was an enterprise too great for any one man, and he used his utmost endeavors to induce James I to become the patron of the plan. His project admits of very simple statement now; he wished to edit an encyclopedia, but feared that it might prove impossible without cooperation and without state support. He felt capable of furnishing the plans for the building, but thought it a hardship that he was compelled to serve both as architect and laborer. The worthiness of these plans was attested in the middle of the eighteenth century, when the great French Encyclopaedia was projected by Diderot and D'Alembert. The former, its chief editor and contributor, wrote in the Prospectus : "If we come out successful from this vast undertaking, we shall owe it mainly to Chancellor Bacon, who sketched the plan of a universal dictionary of sciences and arts at a time when there were not, so to speak, either arts or sciences. This extraordinary genius, when it was impossible to write a history of what men knew, wrote one of what they had to learn."

Bacon, as we shall amply see, was a firm believer in the study of the arts and occupations, and at the same time retained his devotion to principles and abstract thought. He knew that philosophy could aid the arts that supply daily needs; also that the arts and occupations enriched the field of philosophy, 
and that the basis of our generalizations must be the universe of things knowable. "For," he writes, " if men judge that learning should be referred to use and action, they judge well; but it is easy in this to fall into the error pointed out in the ancient fable ; in which the other parts of the body found fault with the stomach, because it neither performed the office of motion as the limbs do, nor of sense, as the head does; but yet notwithstanding it is the stomach which digests and distributes the aliment to all the rest. So that if any man think that philosophy and universality are idle and unprofitable studies, he does not consider that all arts and professions are from thence supplied with sap and strength." For Bacon, as for Descartes, natural philosophy was the trunk of the tree of knowledge.

On the other hand, he looked to the arts, crafts, and occupations as a source of scientific principles. In his survey of learning he found some records of agriculture and likewise of many mechanical arts. Some think them a kind of dishonor. "But if my judgment be of any weight, the use of History Mechanical is, of all others, the most radical and fundamental towards natural philosophy." When the different arts are known, the senses will furnish sufficient concrete material for the information of the understanding. The record of the arts is of most use because it exhibits things in motion, and leads more directly to practice. "Upon this history, therefore, mechanical and illiberal as it may seem (all fineness and daintiness set aside), the greatest diligence must be bestowed." "Again, among the particular arts those are to be preferred which exhibit, alter, and pre- 


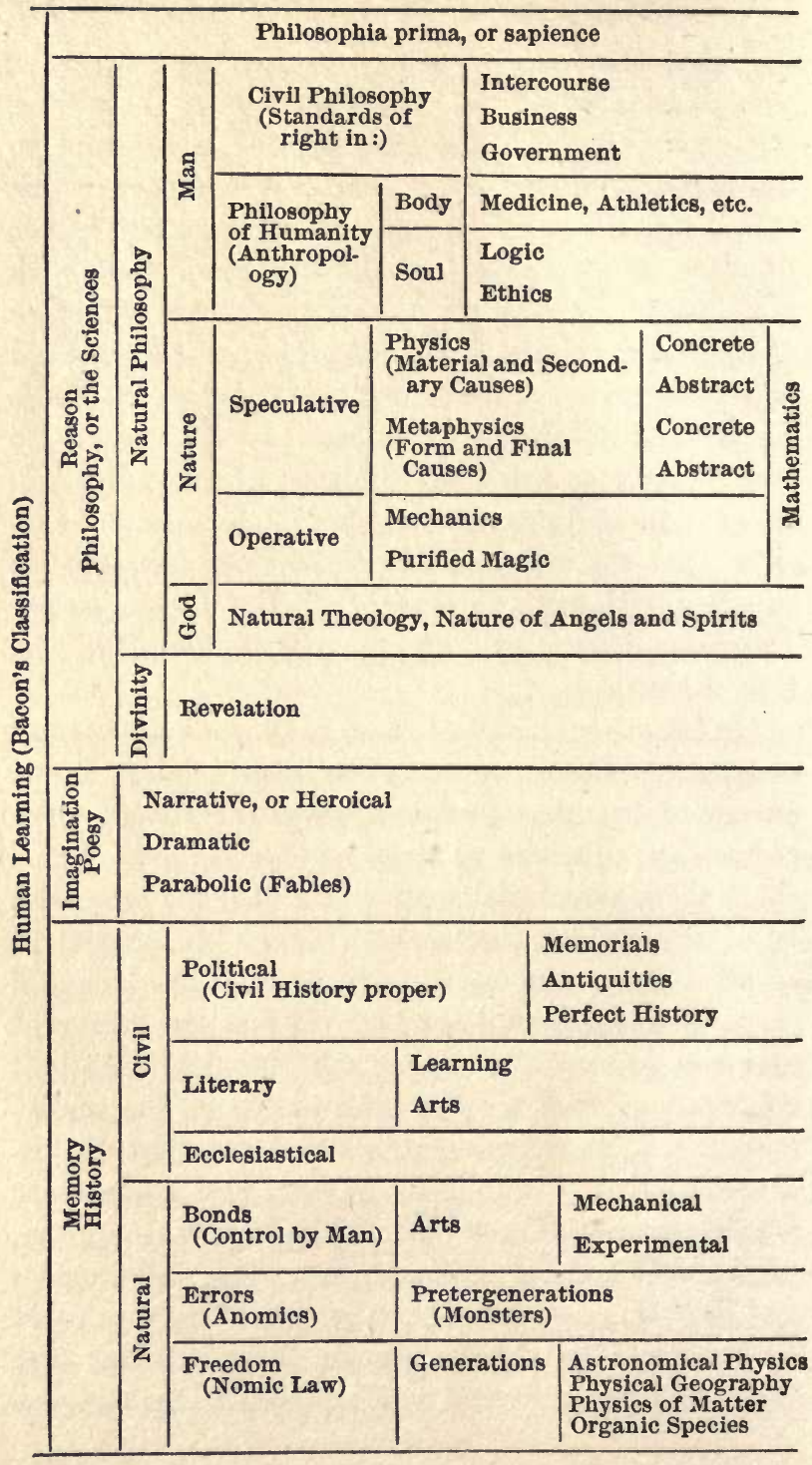




\begin{tabular}{|c|c|c|}
\hline \multirow{3}{*}{ Theoretical } & \multicolumn{2}{|c|}{ Knowledge Classified (Hugo of St. Victor, d. 1141). } \\
\hline & $\begin{array}{l}\text { Theology } \\
\text { Natural Philosophy } \\
\text { (Physic) }\end{array}$ & \\
\hline & Mathematics & $\begin{array}{l}\text { Arithmetie } \\
\text { Music (study of harmony) } \\
\text { Geometry } \\
\text { Astronomy }\end{array}$ \\
\hline $\begin{array}{r}\text { Practical } \\
\text { (Moral) }\end{array}$ & \multicolumn{2}{|c|}{$\begin{array}{l}\text { Ethics, or individual morality } \\
\text { Economics, or family morality } \\
\text { Politics, or civics }\end{array}$} \\
\hline Mechanical & \multicolumn{2}{|c|}{$\begin{array}{l}\text { Weaving, spinning, sewing; work in wool, flax, etc. } \\
\text { Equipment-arms, ships; work in stone, wood, metal } \\
\text { Navigation } \\
\text { Agriculture } \\
\text { Hunting, fishing, foods } \\
\text { Medicine } \\
\text { Theatricals - drama, music, athletics, etc. }\end{array}$} \\
\hline Logical & $\begin{array}{l}\text { Oratory } \\
\text { Grammar } \\
\text { Dialectic } \\
\text { Rhetoric }\end{array}$ & \\
\hline
\end{tabular}


pare natural bodies and materials of things as agriculture, cooking, chemistry, dyeing; the manufacture of glass, enamel, sugar, gunpowder, artificial fires, paper and the like." Weaving, carpentry, architecture, manufacture of mills, clocks, etc. follow. The purpose is not solely to bring the arts to perfection, but all mechanical experiments should be as streams flowing from all sides into the sea of philosophy.

Shortly after James I came to the throne in 1603 , Bacon published his Advancement of Learning. He continued in other writings, however, to develop the organization of knowledge, and in 1623 summed up his plan in the De Augmentis Scientiarum.

A recent writer (Pearson, 1900) has attempted to summarize Bacon's classification of the different branches of learning. When one compares this summary with an outline of the classification of knowledge made by the French monk, Hugo of St. Victor, who stands midway between Isidore of Seville (570636 ) and Bacon, some points of resemblance are of course obvious. Moreover, Hugo, like Bacon, insisted on the importance of not being narrowly utilitarian. Men, he says, are often accustomed to value knowledge not on its own account but for what it yields. Thus it is with the arts of husbandry, weaving, painting, and the like, where skill is considered absolutely vain, unless it results in some useful product. If, however, we judged after this fashion of Grod's wisdom, then, no doubt, the creation would be preferred to the Creator. But wisdom is life, and the love of wisdom is the joy of life (felicitas vitoe).

Nevertheless, when we compare these classifications diligently, we find very marked differences between 


\section{CLASSIFICATION OF THE SCIENCES 63}

Bacon's views and the medieval. The weakest part of Hugo's classification is that which deals with natural philosophy. Physica, he says, undertakes the investigation of the causes of things in their effects, and of effects in their causes. It deals with the explanation of earthquakes, tides, the virtues of plants, the fierce instincts of wild animals, every species of stone, shrub, and reptile. When we turn to his special work, however, on this branch of knowledge, Concerning Beasts and Other Things, we find no attempt to subdivide the field of physica, but a series of details in botany, geology, zoölogy, and human anatomy, mostly arranged in dictionary form.

When we refer to Bacon's classification we find that Physics corresponds to Hugo's Physica. It studies natural phenomena in relation to their material causes. For this study, Natural History, according to Bacon, supplies the facts. Let us glance, then, at his work on natural history, and see how far he had advanced from the medieval toward the modern conception of the sciences.

For purposes of scientific study he divided the phenomena of the universe into (1) Celestial phenomena; (2) Atmosphere; (3) Globe; (4) Substance of earth, air, fire, water; (5) Genera, species, etc. Great scope is given to the natural history of man. The arts are classified as nature modified by man. History means, of course, descriptive science. 
Bacon's Catalogue of Particular Histories by Titles (1620)

1. History of the Heavenly Bodies; or Astronomical History.

2. History of the Configuration of the Heavens and the parts thereof towards the Earth and the parts thereof; or Cosmographical History.

3. History of Comets.

4. History of Fiery Meteors.

5. History of Lightnings, Thunderbolts, Thunders, and Coruscations.

6. History of Winds and Sudden Blasts and Undulations of the Air.

7. History of Rainbows.

8. History of Clouds, as they are seen above.

9. History of the Blue Expanse, of Twilight, of MockSuns, Mock-Moons, Haloes, various colours of the Sun; and of every variety in the aspect of the heavens caused by the medium.

10. History of Showers, Ordinary, Stormy, and Prodigious; also of Waterspouts (as they are called); and the like.

11. History of Hail, Snow, Frost, Hoar-frost, Fog, Dew, and the like.

12. History of all other things that fall or descend from above, and that are generated in the upper region.

13. History of Sounds in the upper region (if there be any), besides Thunder.

14. History of Air as a whole, or in the Configuration of the World.

15. History of the Seasons or Temperatures of the Year, as well according to the variations of Regions as according to accidents of Times and Periods of Years; of Floods, Heats, Droughts, and the like.

16. History of Earth and Sea; of the Shape and Compass of them, and their Configurations compared with each other; and of their broadening or narrowing; of Islands in the Sea; of Gulfs of the Sea, and Salt Lakes within the Land; Isthmuses and Promontories. 
17. History of the Motions (if any be) of the Globe of Earth and Sea; and of the Experiments from which such motions may be collected.

18. History of the greater motions and Perturbations in Earth and Sea; Earthquakes, Tremblings and Yawnings of the Earth, Islands newly appearing; Floating Islands; Breakings off of Land by entrance of the Sea, Encroachments and Inundations and contrariwise Recessions of the Sea; Eruptions of Fire from the Earth; Sudden Eruptions of Waters from the Earth; and the like.

19. Natural History of Geography; of Mountains, Vallies, Woods, Plains, Sands, Marshes, Lakes, Rivers, Torrents, Springs, and every variety of their course, and the like; leaving apart Nations, Provinces, Cities, and such like matters pertaining to Civil life.

20. History of Ebbs and Flows of the Sea; Currents, Undulations, and other Motions of the Sea.

21. History of other Accidents of the Sea; its Saltness, its various Colours, its Depth; also of Rocks, Mountains, and Vallies under the Sea, and the like.

\section{Next come Histories of the Greater Masses}

22. History of Flame and'of things Ignited.

23. History of Air, in Substance, not in the Configuration of the World.

24. History of Water, in Substance, not in the Configuration of the World.

25. History of the Earth and the diversity thereof, in Substance, not in the Configuration of the World.

\section{Next come Histories of Species}

26. History of perfect Metals, Gold, Silver; and of the Mines, Veins, Marcasites of the same; also of the Working in the Mines.

27. History of Quicksilver.

28. History of Fossils; as Vitriol, Sulphur, etc.

29. History of Gems; as the Diamond, the Ruby, etc. 
30. History of Stones; as Marble, Touchstone, Flint, etc.

31. History of the Magnet.

32. History of Miscellaneous Bodies, which are neither entirely Fossil nor Vegetable; as Salts, Amber, Ambergris, etc.

33. Chemical History of Metals and Minerals.

34. History of Plants, Trees, Shrubs, Herbs; and of their parts, Roots, Stalks, Wood, Leaves, Flowers, Fruits, Seeds, Gums, etc.

35. Chemical History of Vegetables.

36. History of Fishes, and the Parts and Generation of them.

37. History of Birds, and the Parts and Generation of them.

38. History of Quadrupeds, and the Parts and Generation of them.

39. History of Serpents, Worms, Flies, and other insects; and of the Parts and Generation of them.

40. Chemical History of the things which are taken by Animals.

\section{Next come Histories of Man}

41. History of the Figure and External Limbs of man, his Stature, Frame, Countenance, and Features; and of the variety of the same according to Races and Climates, or other smaller differences.

42. Physiognomical History of the same.

43. Anatomical History, or of the Internal Members of Man; and of the variety of them, as it is found in the Natural Frame and Structure, and not merely as regards Diseases and Accidents out of the course of Nature.

44. History of the parts of Uniform Structure in Man; as Flesh, Bones, Membranes, etc.

45. History of Humours in Man; Blood, Bile, Seed, etc. 46. History of Excrements; Spittle, Urine, Sweats, Stools, Hair of the Head, Hairs of the Body, Whitlows, Nails, and the like.

47. History of Faculties; Attraction, Digestion, Reten- 
tion, Expulsion, Sanguification, Assimilation of Aliment into the members, conversion of Blood and Flower of Blood into Spirit, etc.

48. History of Natural and Involuntary Motions; as Motion of the Heart, the Pulses, Sneezing, Lungs, Erection, etc.

49. History of Motions partly Natural and Partly Violent; as of Respiration, Cough, Urine, Stool, etc.

50. History of Voluntary Motions; as of the Instruments of Articulation of Words; Motions of the Eyes, Tongue, Jaws, Hands, Fingers; of Swallowing, etc.

51. History of Sleep and Dreams.

52. History of different habits of Body - Fat, Lean; of the Complexions (as they call them), etc.

53. History of the Generation of Man.

54. History of Conception, Vivification, Gestation in the Womb, Birth, etc.

55. History of the Food of Man; and of all things Eatable and Drinkable; and of all Diet; and of the variety of the same according to nations and smaller differences.

56. History of the Growth and Increase of the Body, in the whole and in its parts.

57. History of the Course of Age; Infancy, Boyhood, Youth, Old Age; of Length and Shortness of Life, and the like, according to nations and lesser differences.

58. History of Life and Death.

59. History Medicinal of Diseases, and of the Symptoms and Signs of them.

60. History Medicinal of the Treatment and Remedies and Cures of Diseases.

61. History Medicinal of those things which preserve the Body and the Health.

62. History Medicinal of those things which relate to the Form and Comeliness of the Body.

63. History Medicinal of those things which alter the Body, and pertain to Alterative Regimen.

64. History of Drugs. 


\section{THE HISTORY OF SCIENCE}

65. History of Surgery.

66. Chemical History of Medicines.

67. History of Vision, and of things Visible.

68. History of Painting, Sculpture, Modelling, etc.

69. History of Hearing and Sound.

70. History of Music.

71. History of Smell and Smells.

72. History of Taste and Tastes.

73. History of Touch, and the objects of Touch.

74. History of Venus, as a species of Touch.

75. History of Bodily Pains, as species of Touch.

76. History of Pleasure and Pain in general.

77. History of the Affections; as Anger, Love, Shame, etc.

78. History of the Intellectual Faculties; Reflexion, Imagination, Discourse, Memory, etc.

79. History of Natural Divinations.

80. History of Diagnostics, or Secret Natural Judgements.

81. History of Cookery, and of the arts thereto belonging, as of the Butcher, Poulterer, etc.

82. History of Baking, and the Making of Bread, and the arts thereto belonging, as of the Miller, etc.

83. History of Wine.

84. History of the Cellar and of different kinds of Drink.

85. History of Sweetmeats and Confections.

86. History of Honey.

87. History of Sugar.

88. History of the Dairy.

89. History of Baths and Ointments.

90. Miscellaneous History concerning the care of the body - as of Barbers, Perfumers, etc.

91. History of the working of Gold, and the arts thereto belonging.

92. History of the manufactures of Wool, and the arts thereto belonging.

93. History of the manufactures of Silk, and the arts thereto belonging.

94. History of the manufactures of Flax, Hemp, Cotton, 
Hair, and other kinds of Thread, and the arts thereto belonging.

95. History of manufactures of Feathers.

96. History of Weaving, and the arts thereto belonging. 97. History of Dyeing.

98. History of Leather-making, Tanning, and the arts thereto belonging.

99. History of Ticking and Feathers.

100. History of working in Iron.

101. History of Stone-cutting.

102. History of the making of Bricks and Tiles.

103. History of Pottery.

104. History of Cements, etc.

105. History of working in Wood.

106. History of working in Lead.

107. History of Glass and all vitreous substances, and of Glass-making.

108. History of Architecture generally.

109. History of Waggons, Chariots, Litters, etc.

110. History of Printing, of Books, of Writing, of Sealing; of Ink, Pen, Paper, Parchment, etc.

111. History of Wax.

112. History of Basket-making.

113. History of Mat-making, and of manufactures of Straw, Rushes, and the like.

114. History of Washing, Scouring, etc.

115. History of Agriculture, Pasturage, Culture of Woods, etc.

116. History of Gardening.

117. History of Fishing.

118. History of Hunting and Fowling.

119. History of the Art of War, and of the arts thereto belonging, as Armoury, Bow-making, Arrow-making, Musketry, Ordnance, Cross-bows, Machines, etc.

120. History of the Art of Navigation, and of the crafts and arts thereto belonging.

121. History of Athletics and Human Exercises of all kinds. 122. History of Horsemanship.

123. History of Games of all kinds.

124. History of Jugglers and Mountebanks. 
125. Miscellaneous History of various Artificial Materials, - Enamel, Porcelain, various cements, etc.

126. History of Salts.

127. Miscellaneous History of various Machines and Motions.

128. Miscellaneous History of Common Experiments which have not grown into an Art.

Histories must also be written of Pure Mathematics; though they are rather observations than experiments

129. History of the Natures and Powers of Numbers. 130. History of the Natures and Powers of Figures.

The fragment containing this catalogue (Parasceve - Day of Preparation) was added to Bacon's work on method, The New Logic (Novum Organum), 1620. Besides completing his survey and classification of the sciences (De Augmentis Scientiarum), 1623 , he published a few separate writings on topics in the catalogue - Winds, Life and Death, Tides, etc. In 1627 , a year after his death, appeared his much misunderstood work, Sylva Sylvarum. He had found that the Latin word sylva meant stuff or raw material, as well as a wood, and called this final work Sylva Sylvarum, which I would translate, "Jungle of Raw Material." He himself referred to it as "an undigested heap of particulars"; yet he was willing it should be published because "he preferred the good of men to anything that might have relation to himself." In it, following his catalogue, he fulfilled the promise made in 1620 , of putting nature and the arts to question. Some of the problems suggested for investigation are : congealing of air, turning air into water, the secret nature of flame, motion of gravity, 
production of cold, nourishing of young creatures in the egg or womb, prolongation of life, the media of sound, infectious diseases, accelerating and preventing putrefaction, accelerating and staying growth, producing fruit without core or seed, production of composts and helps for ground, flying in the air.

In the New Atlantis, a work of imagination, Bacon had represented as already achieved for mankind some of the benefits he wished for: artificial metals, various cements, excellent dyes, animals for vivisection and medical experiment, instruments which generate heat solely by motion, artificial precious stones, conveyance of sound for great distances and in tortuous lines, new explosives. "We imitate," says the guide in the Utopian land, "also flights of birds; we have some degree of flying in the air; we have ships and boats for going under water." Bacon believed in honoring the great discoverers and inventors, and advocated maintaining a calendar of inventions.

He was a fertile and stimulating thinker, and much of his great influence arose from the comprehensiveness that led to his celebrated classification of the sciences.

\section{REFERENCES}

Bacon's Philosophical Works, vol. rv, Parasceve, edited by R. L. Ellis, J. Spedding, and D. D. Heath.

Karl Pearson, Grammar of Science.

J. A. Thomson, Introduction to Science. 


\section{CHAPTER VI}

SCIENTIFIC METHOD - GILBERT, GALILEO, HARVEY, DESCARTES

THE previous chapter has given some indication of the range of the material which was demanding scientific investigation at the end of the sixteenth and the beginning of the seventeenth century. The same period witnessed a conscious development of the method, or methods, of investigation. As we have seen, Bacon wrote in 1620 a considerable work, The New Logic (Novum Organum), so called to distinguish it from the traditional deductive logic. It aimed to furnish the organ or instrument, to indicate the correct mental procedure, to be employed in the discovery of natural law. Some seventeen years later, the illustrious Frenchman René Descartes (1596-1650) published his Discourse on the Method of rightly conducting the Reason and seeking Truth in the Sciences. Both of these philosophers illustrated by their own investigations the efficiency of the methods which they advocated.

Before 1620, however, the experimental method had already yielded brilliant results in the hands of other scientists. We pass over Leonardo da Vinci and many others in Italy and elsewhere, whose names should be mentioned if we were tracing this method to its origin. By 1600 William Gilbert (1540-1603), physician to Queen Elizabeth, before whom, as a picture in his birthplace illustrates, he was called to 

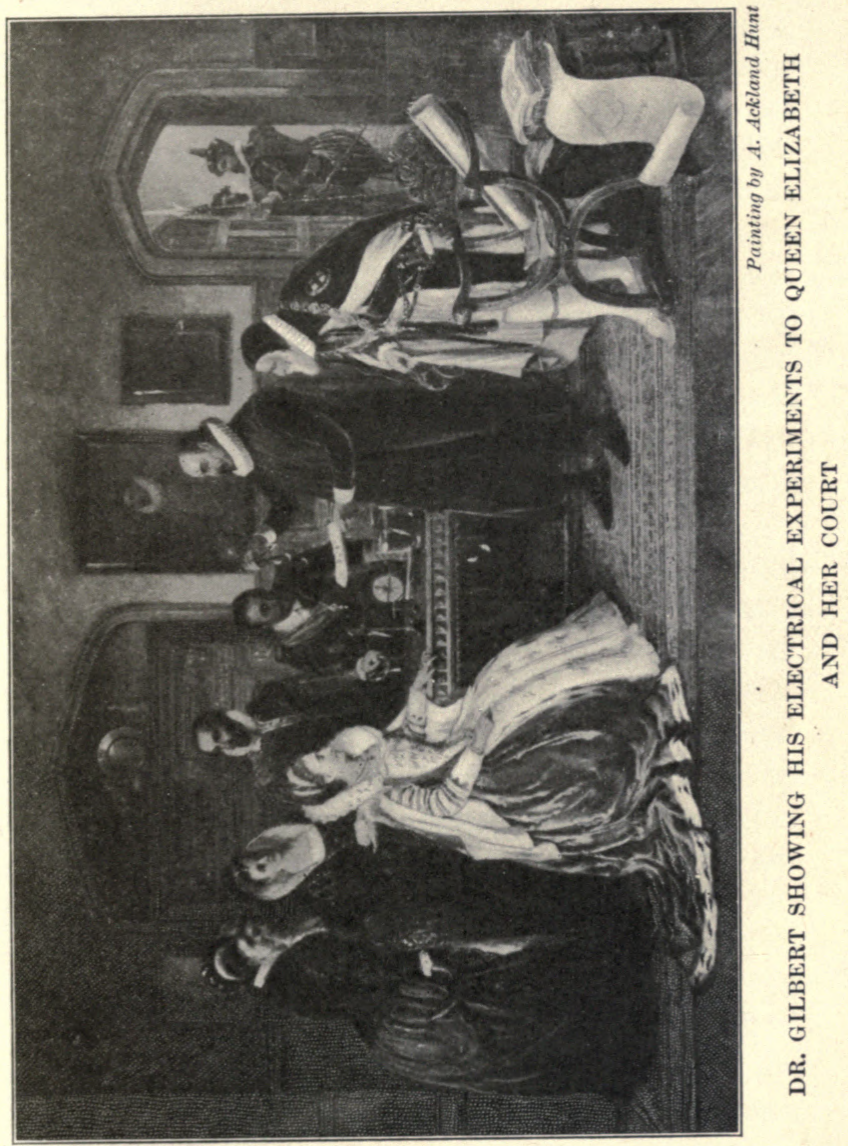

demonstrate his discoveries, had published his work on the Magnet, the outcome of about eighteen years of critical research. He may be considered the founder of electrical science. Galileo, who discovered the fundamental principles of dynamies and thus laid the basis of modern physical science, although he did not publish his most important work till 1638, had even before the close of the sixteenth century prepared the way for the announcement of his principles by years of strict experiment. By the year 1616 , William Harvey (1578-1657), physician at the court of James I, and, later, of Charles I, had, as the first modern experimental physiologist, gained important results through his study of the circulation of the blood.

It is not without significance that both Gilbert and Harvey had spent years in Italy, where, as we have implied, the experimental method of scientific research was early developed. Harvey was at Padua (1598-1602) within the time of Galileo's popular professoriate, and may well have been inspired by the physicist to explain on dynamical principles the flow of blood through arteries and veins. This conjecture is the more probable, since Galileo, like Harvey and Gilbert, had been trained in the study of medicine. Bacon in turn had in his youth learned something of the experimental method on the Continent of Europe, and, later, was well aware of the studies of Gilbert and Galileo, as well as of Harvey, who was indeed his personal physician.

Although these facts seem to indicate that method may be transmitted in a nation or a profession, or through personal association, there still remains some doubt as to whether anything so intimate as the 
mental procedure involved in invention and in the discovery of truth can be successfully imparted by instruction. The individuality of the man of genius engaged in investigation must remain a factor diffcult to analyze. Bacon, whose purpose was to hasten man's empire over nature through increasing the number of inventions and discoveries, recognized that the method he illustrated is not the sole method of scientific investigation. In fact, he definitely states that the method set forth in the Novum Organum is not original, or perfect, or indispensable. He was aware that his method tended to the ignoring of genius and to the putting of intelligences on one level. He knew that, although it is desirable for the investigator to free his mind from prepossessions, and to avoid premature generalizations, interpretation is the true and natural work of the mind when free from impediments, and that the conjecture of the man of genius must at times anticipate the slow process of painful induction. As we shall see in the nineteenth chapter, the psychology of to-day does not know enough about the workings of the mind to prescribe a fixed mental attitude for the investigator. Nevertheless, Bacon was not wrong in pointing out the virtues of a method which he and many others turned to good account. Let us first glance, however, at the activities of those scientists who preceded Bacon in the employment of the experimental method.

Gilbert relied, in his investigations, on oft-repeated and verifiable experiments, as can be seen from his work De Magnete. He directs the experimenter, for example, to take a piece of loadstone of convenient size and turn it on a lathe to the form of a ball. It 
then may be called a terrella, or earthkin. Place on it a piece of iron wire. The ends of the wire move round its middle point and suddenly come to a standstill. Mark with chalk the line along which the wire lies still and sticks. Then move the wire to other spots on the terrella and repeat your procedure. The lines thus marked, if produced, will form meridians, all coming together at the poles. Again, place the magnet in a wooden vessel, and then set the vessel afloat in a tub or cistern of still water. The north pole of the stone will seek approximately the direction of the south pole of the earth, etc. It was on the basis of scores of experiments of this sort, carried on from about 1582 till 1600, that Gilbert felt justified in concluding that the terrestrial globe is a magnet. This theory has since that time been abundantly confirmed by navigators. The full title of his book is Concerning the Magnet and Magnetic Bodies, and concerning the Great Magnet the Earth: $A$ New Natural History (Physiologia) demonstrated by many Arguments and Experiments. It does not detract from the credit of Gilbert's result to state that his initial purpose was not to discover the nature of magnetism or electricity, but to determine the true substance of the earth, the innermost constitution of the globe. He was fully conscious of his own method and speaks with scorn of certain writers who, having made no magnetical experiments, constructed ratiocinations on the basis of mere opinions and oldwomanishly dreamed the things that were not.

Galileo (1564-1642) even as a child displayed something of the inventor's ingenuity, and when he was nineteen, shortly after the beginning of Gilbert's 
experiments, his keen perception for the phenomena of motion led to his making a discovery of great scientific moment. He observed a lamp swinging by a long chain in the cathedral of his native city of Pisa, and noticed that, no matter how much the range of the oscillations might vary, their times were constant. He verified his first impressions by counting his pulse, the only available timepiece. Later he invented simple pendulum devices for timing the pulse of patients, and even made some advances in applying his discovery in the construction of pendulum clocks.

In 1589 he was appointed professor of mathematics in the University of Pisa, and within a year or two established through experiment the foundations of the science of dynamics. As early as $\mathbf{1 5 9 0}$ he put on record, in a Latin treatise Concerning Motion (De Motu), his dissent from the theories of Aristotle in reference to moving bodies, confuting the Philosopher both by reason and ocular demonstration. Aristotle had held that two moving bodies of the same sort and in the same medium have

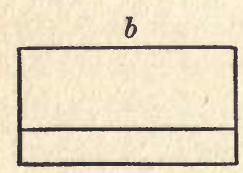

velocities in proportion to their weights. If a moving body, whose weight is represented by $b$, be carried through the line $c-e$ which is divided in the point $d$, if, also, the moving body is divided according to the same proportion as line $c-e$ is in the point $d$, it is manifest that in the time taken to carry the whole body through $c-e$, the part will be moved through $c-d$. Galileo said that it is as clear as day- 
light that this view is ridiculous, for who would believe that when two lead spheres are dropped from a great height, the one being a hundred times heavier than the other, if the larger took an hour to reach the earth, the smaller would take a hundred hours? Or, that if from a high tower two stones, one twice the weight of the other, should be pushed out at the same moment, the larger would strike the ground while the smaller was still midway? His biography tells that Galileo in the presence of professors and students dropped bodies of different weights from the height of the Leaning Tower of Pisa to demonstrate the truth of his views. If allowance be made for the friction of the air, all bodies fall from the same height in equal times: the final velocities are proportional to the times; the spaces passed through are proportional to the squares of the times. The experimental basis of the last' two statements was furnished by means of an inclined plane, down a smooth groove in which a bronze ball was allowed to pass, the time being ascertained by means of an improvised water-clock.

Galileo's mature views on dynamics received expression in a work published in 1638, Mathematical Discourses and Demonstrations concerning Two New Sciences relating to Mechanics and Local Movements. It treats of cohesion and resistance to fracture (strength of materials), and uniform, accelerated, and projectile motion (dynamics). The discussion is in conversation form. The opening sentence shows Galileo's tendeney to base theory on the empirical. It might be freely translated thus: "Large scope for intellectual speculation, I should think, 
would be afforded, gentlemen, by frequent visits to your famous Venetian Dockyard (arsenale), especially that part where mechanics are in demand; seeing that there every sort of instrument and machine is put to use by numbers of workmen, among whom, taught both by tradition and their own observation, there must be some very skillful and also able to talk." The view of the shipbuilders, that a large galley before being set afloat is in greater danger of breaking under its own weight than a small galley, is the starting-point of this most important of Galileo's contributions to science.

Vesalius (1514-1564) had in his work on the structure of the human body (De Humani Corporis Fabrica, 1543) shaken the authority of Galen's anatomy; it remained for Harvey on the basis of the new anatomy to improve upon the Greek physician's experimental physiology. Harvey professed to learn and teach anatomy, not from books, but from dissections, not from the dogmas of the philosophers, but from the fabric of nature.

There have come down to us notes of his lectures on anatomy delivered first in 1616. A brief extract will show that even at that date he had already formulated a theory of the circulation of the blood:-

" $W \mathcal{H}^{1} \mathrm{By}$ the structure of the heart it appears that the blood is continually transfused through the lungs to the aorta - as by the two clacks of a waterram for raising water.

"It is shown by ligature that there is continuous motion of the blood from arteries to veins.

1 This is Harvey's monogram, which he used in his notes to mark any original observation. 
"Whence $\Delta$ it is demonstrated that there is a continuous motion of the blood in a circle, affected by the beat of the heart."

It was not till 1628 that Harvey published his Anatomical Disquisition on the Motion of the Heart and Blood in Animals. It gives the experimental basis of his conclusions. If a live snake be laid open, the heart will be seen pulsating and propelling its contents. Compress the large vein entering the heart, and the part intervening between the point of constriction and the heart becomes empty and the organ pales and shrinks. Remove the pressure, and the size and color of the heart are restored. Now compress the artery leading from the organ, and the part between the heart and the point of pressure, and the heart itself, become distended and take on a deep purple color. The course of the blood is evidently from the vena cava through the heart to the aorta. Harvey in his investigations made use of many species of animals - at least eighty-seven.

It was believed by some, before Harvey's demonstrations, that the arteries were hollow pipes carrying air from the lungs throughout the body, although Galen had shown by cutting a dog's trachea, inflating the lungs and tying the trachea, that the lungs were in an enclosing sack which retained the air. Harvey, following Galen, held that the pulmonary artery, carrying blood to the lungs from the right side of the heart, and the pulmonary veins, carrying blood from the lungs to the left side of the heart, intercommunicate in the hidden porosities of the lungs and through minute inosculations.

In man the vena cava carries the blood to the right 
side of the heart, the pulmonary artery inosculates with the pulmonary veins, which convey it to the left side of the heart. This muscular pump drives it into the aorta. It still remains to be shown that in the limbs the blood passes from the arteries to the veins. Bandage the arm so tightly that no pulse is felt at the wrist. The hand appears at first natural, and then grows cold. Loose the bandage sufficiently to restore the pulse. The hand and forearm become suffused and swollen. In the first place the supply of blood from the deep-lying arteries is cut off. In the second case the blood returning by the superficial veins is dammed back. In the limbs as in the lungs the blood passes from artery to vein by anastomoses and porosities. All these arteries have their source in the aorta; all these veins pour their stream ultimately into the vena cava. The veins have valves, which prevent the blood flowing except toward the heart. Again, the veins and arteries form a connected system; for through either a vein or an artery all the blood may be drained off. The arguments by which Harvey supported his view were various. The opening clause of his first chapter, "When I first gave my mind to vivisection as a means of discovering the motions and uses of the heart," throws a strong light on his special method of experimental investigation.

Bacon, stimulated by what he called philanthropia, always aimed, as we have seen, to establish man's control over nature. But all power of a high order depends on an understanding of the essential character, or law, of heat, light, sound, gravity, and the like. Nothing short of a knowledge of the underly- 
ing nature of phenomena can give science advantage over chance in hitting upon useful discoveries and inventions. It is, therefore, natural to find him applying his method of induction - his special method of true induction - to the investigation of heat.

In the first place, let there be mustered, without premature speculation, all the instances in which heat is manifested - flame, lightning, sun's rays, quicklime sprinkled with water, damp hay, animal heat, hot liquids, bodies subjected to friction. Add to these, instances in which heat seems to be absent, as moon's rays, sun's rays on mountains, oblique rays in the polar circle. Try the experiment of concentrating on a thermoscope, by means of a burningglass, the moon's rays. Try with the burning-glass to concentrate heat from hot iron, from common flame, from boiling water. Try a concave glass with the sun's rays to see whether a diminution of heat results. Then make record of other instances, in which heat is found in varying degrees. For example, an anvil grows hot under the hammer. A thin plate of metal under continuous blows might grow red like ignited iron. Let this be tried as an experiment.

After the presentation of these instances induction itself must be set to work to find out what factor is ever present in the positive instances, what factor is ever wanting in the negative instances, what factor always varies in the instances which show variation. According to Bacon it is in the process of exclusion that the foundations of true induction are laid. We can be certain, for example, that the essential nature of heat does not consist in light and 
brightness, since it is present in boiling water and absent in the moon's rays.

The induction, however, is not complete till something positive is established. At this point in the investigation it is permissible to venture an hypothesis in reference to the essential character of heat. From a survey of the instances, all and each, it appears that the nature of which heat is a particular case is motion. This is suggested by flame, simmering liquids, the excitement of heat by motion, the extinction of fire by compression, etc. Motion is the genus of which heat is the species. Heat itself, its essence, is motion and nothing else.

It remains to establish its specific differences. This accomplished, we arrive at the definition : Heat is a motion, expansive, restrained, and acting in its strife upon the smaller particles of bodies. Bacon, glancing toward the application of this discovery, adds: "If in any natural body you can excite a dilating or expanding motion, and can so repress this motion and turn it back upon itself, that the dilation shall not proceed equally, but have its way in one part and be counteracted in another, you will undoubtedly generate heat." The reader will recall that Bacon looked for the invention of instruments that would generate heat solely by motion.

Descartes was a philosopher and mathematician. In his Discourse on Method and his Rules for the Direction of the Mind (1628) he laid emphasis on deduction rather than on induction. In the subordination of particulars to general principles he experienced a satisfaction akin to the sense of beauty or the joy of artistic production. He speaks enthusi- 


\section{SCIENTIFIC METHOD}

astically of that pleasure which one feels in truth, and which in this world is about the only pure and unmixed happiness.

At the same time he shared Bacon's distrust of the Aristotelian logic and maintained that ordinary dialectic is valueless for those who desire to investigate the truth of things. There is need of a method for finding out the truth. He compares himself to a smith forced to begin at the beginning by fashioning tools with which to work.

In his method of discovery he determined to accept nothing as true that he did not clearly recognize to be so. He stood against assumptions, and insisted on rigid proof. Trust only what is completely known. Attain a certitude equal to that of arithmetic and geometry. This attitude of strict criticism is characteristic of the scientific mind.

Again, Descartes was bent on analyzing each difficulty in order to solve it; to neglect no intermediate steps in the deduction, but to make the enumeration of details adequate and methodical. Preserve a certain order; do not attempt to jump from the ground to the gable, but rise gradually from what is simple and easily understood.

Descartes' interest was not in the several branches of mathematics; rather he wished to establish a universal mathematics, a general science relating to order and measurement. He considered all physical nature, including the human body, as a mechanism, capable of explanation on mathematical principles. But his immediate interest lay in numerical relationships and geometrical proportions.

Recognizing that the understanding was depend- 
ent on the other powers of the mind, Descartes resorted in his mathematical demonstrations to the use of lines, because he could find no method, as he says, more simple or more capable of appealing to the imagination and senses. He considered, however, that in order to bear the relationships in memory or to embrace several at once, it was essential to explain them by certain formulæ, the shorter the better. And for this purpose it was requisite to borrow all that was best in geometrical analysis and algebra, and to correct the errors of one by the other.

Descartes was above all a mathematician, and as such he may be regarded as a forerunner of Newton and other scientists; at the same time he developed an exact scientific method, which he believed applicable to all departments of human thought. "Those long chains of reasoning," he says, "quite simple and easy, which geometers are wont to employ in the accomplishment of their most difficult demonstrations, led me to think that everything which might fall under the cognizance of the human mind might be connected together in the same manner, and that, provided only one should take care not to receive anything as true which was not so, and if one were always careful to preserve the order necessary for deducing one truth from another, there would be none so remote at which he might not at last arrive, or so concealed which he might not discover." 


\section{SCIENTIFIC METHOD}

\section{REFERENCES}

Francis Bacon, Philosophical Works (Ellis and Spedding edition), vol. Iv, Novum Organum.

J. J. Fahie, Galileo; His Life and Work.

Galileo, Two New Sciences; translated by Henry Crew and Alphonse De Salvio.

William Gilbert, On the Loadstone; translated by P. F. Mottelay.

William Harvey, An Anatomical Disquisition on the Motion of the Heart and Blood in Animals.

T. H. Huxley, Method and Results.

D'Arcy Power, William Harvey (in Masters of Medicine). 


\section{CHAPTER VII}

SCIENCE AS MEASUREMENT - TYCHO BRAHE,

KEPLER, BOYLE

Considering the value for clearness of thought of counting, measuring and weighing, it is not surprising to find that in the seventeenth century, and even at the end of the sixteenth, the advance of the sciences was accompanied by increased exactness of measurement and by the invention of instruments of precision. The improvement of the simple microscope, the invention of the compound microscope, of the telescope, the micrometer, the barometer, the thermoscope, the thermometer, the pendulum clock, the improvement of the mural quadrant, sextant, spheres, astrolabes, belong to this period.

Measuring is a sort of counting, and weighing a form of measuring. We may count disparate things whether like or unlike. When we measure or weigh we apply a standard and count the times that the unit - cubit, pound, hour - is found to repeat itself. We apply our measure to uniform extension, meting out the waters by fathoms or space by the sun's diameter, and even subject time to arbitrary divisions. The human mind has been developed through contact with the multiplicity of physical objects, and we find it impossible to think clearly and scientifically about our environment without dividing, weighing, measuring, counting.

In measuring time we cannot rely on our inward 
impressions; we even criticize these impressions and speak of time as going slowly or quickly. We are compelled in the interests of accuracy to provide an objective standard in the clock, or the revolving earth, or some other measurable thing. Similarly with weight and heat; we cannot rely on the subjective impression, but must devise apparatus to record by a measurable movement the amount of the pressure or the degree of temperature.

"God ordered all things by measure, number, and weight." The scientific mind does not rest satisfied till it is able to see phenomena in their number relationships. Scientific thought is in this sense Pythagorean, that it inquires in reference to quantity and proportion.

As implied in a previous chapter, number relations are not clearly grasped by primitive races. Many primitive languages have no words for numerals higher than five. That fact does not imply that these races do not know the difference between large and small numbers, but precision grows with civilization, with commercial pursuits, and other activities, such as the practice of medicine, to which the use of weights and measures is essential. Scientific accuracy is dependent on words and other means of numerical expression. From the use of fingers and toes, a rude score or tally, knots on a string, or a simple abacus, the race advances to greater refinement of numerical expression and the employment of more and more accurate apparatus.

One of the greatest contributors to this advance was the celebrated Danish astronomer, Tycho Brahe (1546-1601). Before 1597 he had completed his 
great mural quadrant at the observatory of Uraniborg. He called it with characteristic vanity the Tichonic quadrant. It consisted of a graduated are of solid polished brass five inches broad, two inches thick, and with a radius of about six and three quarters feet. Each degree was divided into minutes, and each minute into six parts. Each of these parts was then subdivided into ten seconds, which were indicated by dots arranged in transverse oblique lines on the width of brass.

The arc was attached in the observation room to a wall running exactly north, and so secured with screws (firmissimis cochleis) that no force could move it. With its concavity toward the southern sky it was closely comparable, though reverse, to the celestial meridian throughout its length from horizon to zenith. The south wall, above the point where the radii of the quadrant met, was pierced by a cylinder of gilded brass placed in a rectangular opening, which could be opened or closed from the outside. The observation was made through one of two sights that were attached to the graduated are and could be moved from point to point on it. In the sights were parallel slits, right, left, upper, lower. If the altitude and the transit through the meridian were to be taken at the same time the four directions were to be followed. It was the practice for the student making the observation to read off the number of degrees, minutes, etc., of the angle at which the altitude or transit was observed, so that it might be recorded by a second student. A third took the time from two clock dials when the observer gave the signal, and the exact moment of observation was also recorded by 
5(f)

\section{QVADRANS MVRALIS SIVE TICHONIGVS.}

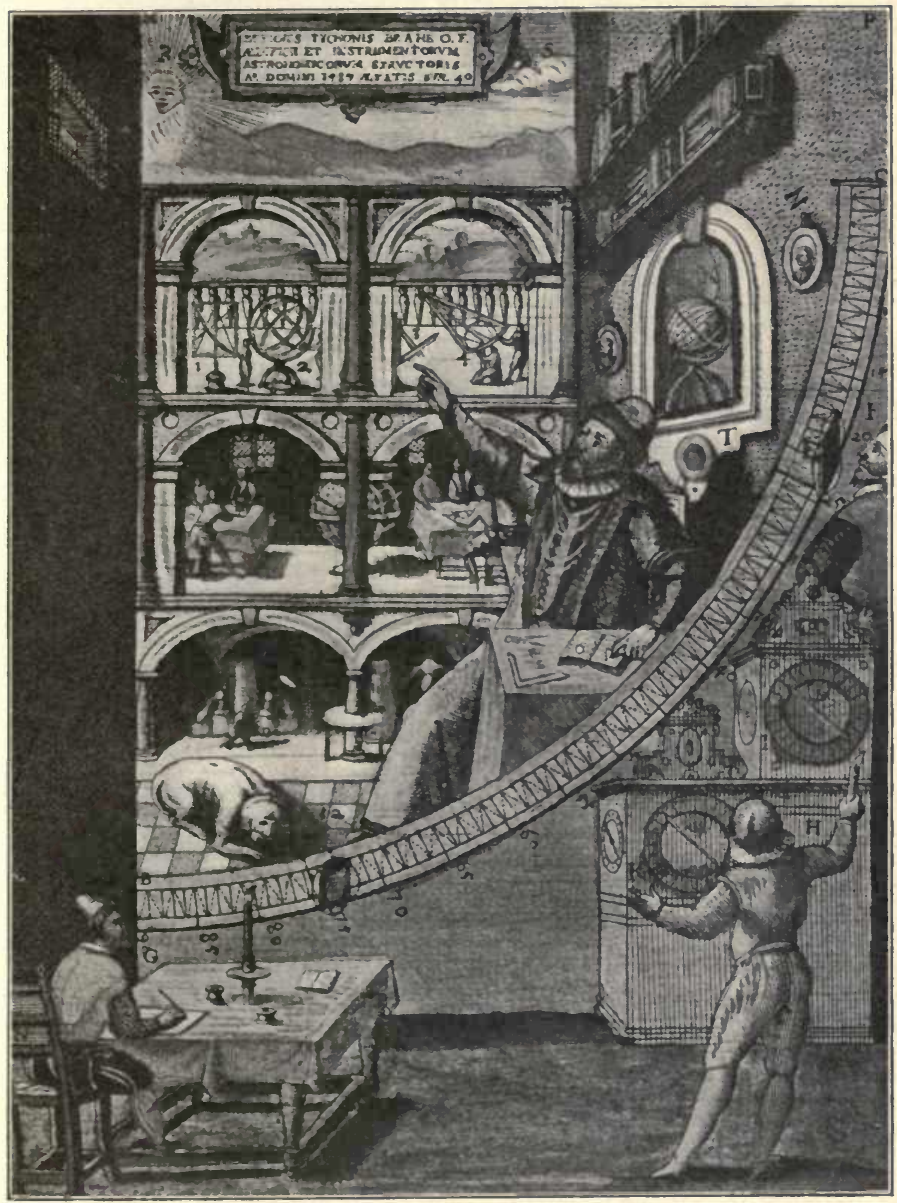



student number two. The clocks recorded minutes and the smaller divisions of time; great care, however, was required to obtain good results from them. There were four clocks in the observatory, of which the largest had three wheels, one wheel of pure solid brass having twelve hundred teeth and a diameter of two cubits.

Lest any space on the wall should lie empty a number of paintings were added: Tycho himself in an easy attitude seated at a table and directing from a book the work of his students. Over his head is an automatic celestial globe invented by Tycho and constructed at his own expense in 1590 . Over the globe is a part of Tycho's library. On either side are represented as hanging small pictures of Tycho's patron, Frederick II of Denmark (d. 1588) and Queen Sophia. Then other instruments and rooms of the observatory are pictured; Tycho's students, of whom there were always at least six or eight, not to mention younger pupils. There appears also his great brass globe six feet in diameter. Then there is pictured Tycho's chemical laboratory, on which he has expended much money. Finally comes one of Tycho's huuting dogs - very faithful and sagacious; he serves here as a hieroglyph of his master's nobility as well as of sagacity and fidelity. The expert architect and the two artists who assisted Tycho are delineated in the landscape and even in the setting sun in the topmost part of the painting, and in the decoration above.

The principal use of this largest quadrant was the determination of the angle of elevation of the stars within the sixth part of a minute, the collinea- 
tion being made by means of one of the sights, the parallel horizontal slits in which were aligned with the corresponding parts of the circumference of the cylinder. The altitude was recorded according to the position of the sight attached to the graduated arc.

Tycho Brahe had a great reverence for Copernicus, but he did not accept his planetary system; and he felt that advance in astronomy depended on painstaking observation. For over twenty years under the kings of Denmark he had good opportunities for pursuing his investigation. The island of Hven became his property. A thoroughly equipped observatory was provided, including printing-press and workshops for the construction of apparatus. As already implied, capable assistants were at the astronomer's command. In 1598, after having left Denmark, Tycho in a splendid illustrated book ( $A s$ tronomice Instauratce Mechanica) gave an account of this astronomical paradise on the Insula Venusia as he at times called it. The book, prepared for the hands of princes, contains about twenty full-page colored illustrations of astronomical instruments (including, of course, the mural quadrant), of the exterior of the observatory of Uraniborg, etc. The author had a consciousness of his own worth, and deserves the name Tycho the Magnificent. The results that he obtained were not unworthy of the apparatus employed in his observations, and before he died at Prague in 1601, Tycho Brahe had consigned to the worthiest hands the painstaking record of his labors.

Johann Kepler (1571-1630) had been called, as 
the astronomer's assistant, to the Bohemian capital in 1600 and in a few months fell heir to Tycho's data in reference to $777 \mathrm{stars}$, which he made the basis of the Rudolphine tables of 1627. Kepler's genius was complementary to that of his predecessor. He was gifted with an imagination to turn observations to account. His astronomy did not rest in mere description, but sought the physical explanation. He had the artist's feeling for the beauty and harmony, which he divined before he demonstrated, in the number relations of the planetary movements. After special studies of Mars based on Tycho's data, he set forth in 1609 (Astronomia Nova) (1) that every planet moves in an ellipse of which the sun occupies one focus, and (2) that the area swept by the radius vector from the planet to the sun is proportional to the time. Luckily for the success of his investigation the planet on which he had concentrated his attention is the one of all the planets then known, the orbit of which most widely differs from a circle. In a later work (Harmonica Mundi, 1619) the title of which, the Harmonics of the Universe, proclaimed his inclination to Pythagorean views, he demonstrated (3) that the square of the periodic time of any planet is proportional to the cube of its mean distance from the sun.

Kepler's studies were facilitated by the invention, in 1614 by John Napier, of logarithms, which have been said, by abridging tedious calculations, to double the life of an astronomer. About the same time Kepler in purchasing some wine was struck by the rough-and-ready method used by the merchant to determine the capacity of the wine-vessels. He applied 
himself for a few days to the problems of mensuration involved, and in 1615 published his treatise (Stereometria Doliorum) on the cubical contents of casks (or wine-jars), a source of inspiration to all later writers on the accurate determination of the volume of solids. He helped other scientists and was himself richly helped. As early as 1610 there had been presented to him a means of precision of the first importance to the progress of astronomy, namely, a Galilean telescope.

The early history of telescopes shows that the effect of combining two lenses was understood by scientists long before any particular use was made of this knowledge; and that those who are accredited with introducing perspective glasses to the public hit by accident upon the invention. Priority was claimed by two firms of spectacle-makers in Middelburg, Holland, namely, Zacharias, miscalled Jansen, and Lippershey. Galileo heard of the contrivance in July, 1609, and soon furnished so powerful an instrument of discovery that things seen through it appeared more than thirty times nearer and almost a thousand times larger than when seen by the naked eye. He was able to make out the mountains in the moon, the satellites of Jupiter in rotation, the spots on the revolving sun; but his telescope afforded only an imperfect view of Saturn. Of course these facts, published in 1610 (Sidereus Nuncius), strengthened his advocacy of the Copernican system. Galileo laughingly wrote Kepler that the professors of philosophy were afraid to look through his telescope lest they should fall into heresy. The German astronomer, who had years before written 
on the optics of astronomy, now (1611) produced his Dioptrice, the first satisfactory statement of the theory of the telescope.

About 1639 Gascoigne, a young Englishman, invented the micrometer, which enables an observer to adjust a telescope with very great precision. Before the invention of the micrometer exactitude was impossible, because the adjustment of the instrument depended on the discrimination of the naked eye. The micrometer was a further advance in exact measurement. Gascoigne's determinations of, for example, the diameter of the sun, bear comparison with the findings of even recent astronomical science.

The history of the microscope is closely connected with that of the telescope. In the first half of the seventeenth century the simple microscope came into use. It was developed from the convex lens, which, as we have seen in a previous chapter, had been known for centuries, if not from remote antiquity. With the simple microscope Leeuwenhoek before 1673 had studied the structure of minute animal organisms and ten years later had even obtained sight of bacteria. Very early in the same century Zacharias had presented Prince Maurice, the commander of the Dutch forces, and the Archduke Albert, governor of Holland, with compound microscopes. Kircher (1601-1680) made use of an instrument that represented microscopic forms as one thousand times larger than their actual size, and by means of the compound microscope Malpighi was able in 1661 to see blood flowing from the minute arteries to the minute veins on the lung and on the distended bladder of the live frog. The Italian microscopist thus, among his many 
achievements, verified by observation what Harvey in 1628 had argued must take place.

In this same epoch apparatus of precision developed in other fields. Weight clocks had been in use as time-measurers since the thirteenth century, but they were, as we have seen, difficult to control and otherwise unreliable. Even in the seventeenth century scientists in their experiments preferred some form of water-clock. In 1636 Galileo, in a letter, mentioned the feasibility of constructing a pendulum clock, and in 1641 he dictated a description of the projected apparatus to his son Vincenzo and to his disciple Viviani. He himself was then blind, and he died the following year. His instructions were never carried into effect. However, in 1657 Christian Huygens applied the pendulum to weight clocks of the old stamp. In 1674 he gave directions for the manufacture of a watch, the movement of which was driven by a spring.

Galileo, to whom the advance in exact science is so largely indebted, must also be credited with the first apparatus for the measurement of temperatures. This was invented before 1603 and consisted of a glass bulb with a long stem of the thickness of a straw. The bulb was first heated and the stem placed in water. The point at which the water, which rose in the tube, might stand was an indication of the temperature. In 1631 Jean Rey just inverted this contrivance, filling the bulb with water. Of course these thermoscopes would register the effect of varying pressures as well as temperatures, and they soon made way for the thermometer and the barometer. Before 1641 a true thermometer was constructed by 
sealing the top of the tube after driving out the air by heat. Spirits of wine were used in place of water. Mercury was not employed till 1670.

Descartes and Galileo had brought under criticism the ancient idea that nature abhors a vacuum. They knew that the horror vacui was not sufficient to raise water in a pump more than about thirty-three feet. They had also known that air has weight, a fact which soon served to explain the so-called force of suction. Galileo's associate Torricelli reasoned that if the pressure of the air was sufficient to support a column of water thirty-three feet in height, it would support a column of mercury of equal weight. Accordingly in 1643 he made the experiment of filling with mercury a glass tube four feet long closed at the upper end, and then opening the lower end in a basin of mercury. The mercury in the tube sank until its level was about thirty inches above that of the mercury in the basin, leaving a vacuum in the upper part of the tube. As the specific gravity of mercury is 13 , Torricelli knew that his supposition had been correct and that the column of mercury in the tube and the column of water in the pump were owing to the pressure or weight of the air.

Pascal thought that this pressure would be less at a high altitude. His supposition was tested on a church steeple at Paris, and, later, on the Puy de Dôme, a mountain in Auvergne. In the latter case a difference of three inches in the column of mercury was shown at the summit and base of the ascent. Later Pascal experimented with the siphon and succeeded in explaining it on the principle of atmospheric pressure. 
Torricelli in the space at the top of his barometer (pressure-gauge) had produced what is called a Torricellian vacuum. Otto von Guericke, a burgomaster of Magdeburg, who had traveled in France and Italy, succeeded in constructing an air-pump by means of which air might be exhausted from a vessel. Some of his results became widely known in 1657 , though his works were not published till 1673.

Robert Boyle (1626-1691), born at Castle Lismore in Ireland, was the seventh son and fourteenth child of the distinguished first Earl of Cork. He was early acquainted with these various experiments in reference to the air, as well as with Descartes' theory that air is nothing but a congeries or heap of small, and, for the most part, flexible particles. In $\mathbf{1 6 5 9}$ he wrote his New Experiments Physico-Mechanical touching the Spring of the Air. Instead of spring, he at times

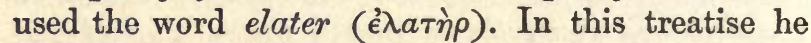
describes experiments with the improved air-pump constructed at his suggestion by his assistant, Robert Hooke.

One of Boyle's critics, a professor at Louvain, while admitting that air had weight and elasticity, denied that these were sufficient to account for the results ascribed to them. Boyle thereupon published a Defence of the Doctrine touching the Spring and Weight of the Air. He felt able to prove that the elasticity of the air could under circumstances do far more than sustain twenty-nine or thirty inches of mercury. In support of his view he cited a recent experiment.

He had taken a piece of strong glass tubing fully twelve feet in length. (The experiment was made 
by a well-lighted staircase, the tube being suspended by strings.) The glass was heated more than a foot from the lower end, and bent so that the shorter leg of twelve inches was parallel with the longer. The former was hermetically sealed at the top and marked off in forty-eight quarter-inch spaces. Into the opening of the longer leg, also graduated, mercury was poured. At first only enough was introduced to fill the arch, or bent part of the tube below the graduated legs. The tube was then inclined so that the air might pass from one leg to the other, and equality of pressure at the start be assured. Then more mercury was introduced and every time that the air in the shorter leg was compressed a half or a quarter of an inch, a record was made of the height of the mercury in the long leg of the tube. Boyle reasoned that the compressed air was sustaining the pressure of the column of mercury in the long leg plus the pressure of the atmosphere at the tube's opening, equivalent to $29 \frac{2}{16}$ inches of mercury. Some of the results were as follows: When the air in the short tube was compressed from 12 to 3 inches, it was under a pressure of $117 \frac{9}{16}$ inches of mercury; when compressed to 4 it was under pressure of $87 \frac{1}{16} \frac{5}{6}$ inches of mercury; when compressed to $6,58 \frac{1}{16}$; to $9,39 \frac{5}{8}$. Of course, when at the beginning of the experiment there were 12 inches of air in the short tube, it was under the pressure of the atmosphere, equal to that of $29 \frac{2}{16}$ inches of mercury. Boyle with characteristic caution was not inclined to draw too general a conclusion from his experiment. However, it was evident, making allowance for some slight irregularity in the experimental results, that air reduced under 
pressure to one half its original volume, doubles its resistance; and that if it is further reduced to one half, - for example, from six to three inches, - it has four times the resistance of common air. In fact, Boyle had sustained the hypothesis that supposes the pressures and expansions to be in reciprocal proportions.

\section{REFERENCES}

Sir Robert S. Ball, Great Astronomers.

Robert Boyle, Works (edited by Thomas Birch).

Sir David Brewster, Martyrs of Science.

J. L. E. Dreyer, Tycho Brahe.

Sir Oliver Lodge, Pioneers of Science.

Flora Masson, Robert Boyle; a Biography. 


\section{CHAPTER VIII}

COÖPERATION IN SCIENCE - THE ROYAL SOCIETY

THe period from 1637 to 1687 affords a good illustration of the value for the progress of science of the coöperation in the pursuit of truth of men of different ereeds, nationalities, vocations, and social ranks. At, or even before, the beginning of that period the need of coöperation was indicated by the activities of two men of pronouncedly social temperament and interests, namely, the French Minim father, Mersenne, and the Protestant Prussian merchant, Samuel Hartlib.

Mersenne was a stimulating and indefatigable correspondent. His letters to Galileo, Jean Rey, Hobbes, Descartes, Gassendi, not to mention other scientists and philosophers, constitute an encyclopedia of the learning of the time. A mathematician and experimenter himself, he had a genius for eliciting discussion and research by means of adroit questions. Through him Descartes was drawn into debate with Hobbes, and with Gassendi, a champion of the experimental method. Through him the discoveries of Harvey, Galileo, and Torricelli, as well as of many others, became widely known. His letters, in the dearth of scientific associations and the absence of scientific periodicals, served as a general news agency among the learned of his time. It is not surprising that a coterie gathered about him at Paris. Hobbes 
spent months in daily intercourse with this group of scientists in the winter of 1636-37.

Hartlib, though he scarcely takes rank with Mersenne as a scientist, was no less influential. Of a generous and philanthropic disposition, he repeatedly impoverished himself in the cause of human betterment. His chief reliance was on education and improved methods of husbandry, but he resembled Horace Greeley in his hospitality to any project for the public welfare.

One of Hartlib's chief hopes for the regeneration of England, if not of the whole world, rested on the teachings of the educational reformer Comenius, a bishop of the Moravian Brethren. In 1637, Comenius having shown himself rather reluctant to put his most cherished plans before the public, his zealous disciple precipitated matters, and on his own responsibility, and unknown to Comenius, issued from his library at Oxford Preludes to the Endeavors of Comenius. Besides Hartlib's preface it contained a treatise by the great educator on a Seminary of Christian Pansophy, a method of imparting an encyclopedic knowledge of the sciences and arts.

The two friends were followers of the Baconian philosophy. They were influenced, as many others of the time, by the New Atlantis, which went through ten editions between 1627 and 1670, and which outlined a plan for an endowed college with thirtysix Fellows divided into groups - what would be called to-day a university of research endowed by the State. It is not surprising to find Comenius (who in his student days had been under the influence of Alsted, author of an encyclopedia on Baco- 


\section{COÖPERATION IN SCEENCE YCL}

nian lines) speaking in $\mathbf{1 6 3 8}$ on the need of a collegiate society for carrying on the educational work that he himself had at heart.

In 1641 Hartlib published a work of fiction in the manner of the New Atlantis, and dedicated it to the Long Parliament. In the same year he urged Comenius to come to London, and published another work, A Reformation of Schools. He had great influence and did not hesitate to use it in his adoptive country. Everybody knew Hartlib, and he was acquainted with all the strata of English society; for although his father had been a merchant, first in Poland and later in Elbing, his mother was the daughter of the Deputy of the English Company in Dantzic and had relatives of rank in London, where Hartlib spent most of his life. He gained the goodwill of the Puritan Government, and even after Cromwell's death was working, in conjunction with Boyle, for the establishment of a national council of universal learning with Wilkins as president.

When Comenius arrived in London he learned that the invitation had been sent by order of Parliament. This body was very anxious to take up the question of education, especially university education. Bacon's criticisms of Oxford and Cambridge were still borne in mind; the legislators considered that the college curriculum was in need of reformation, that there ought to be more fraternity and correspondence among the universities of Europe, and they even contemplated the endowment by the State of scientific experiment. They spoke of erecting a university at London, where Gresham College had been established in 1597 and Chelsea College in 
1610. It was proposed to place Gresham College, the Savoy, or Winchester College, at the disposition of the pansophists. Comenius thought that nothing was more certain than that the design of the great Verulam concerning the opening somewhere of a universal college, devoted to the advancement of the sciences, could be carried out. The impending struggle, however, between Charles I and the Parliament prevented the attempt to realize the pansophic dream, and the Austrian Slav, who knew something of the horrors of civil war, withdrew, discouraged, to the Continent.

Nevertheless, Hartlib did not abandon the cause, but in 1644 broached Milton on the subject of educational reform, and drew from him the brief but influential tract on Education. In this its author alludes rather slightingly to Comenius, who had something of Bacon's infelicity in choice of titles and epithets and who must have seemed outlandish to the author of Lycidas and Comus. But Milton joined in the criticism of the universities - the study of words rather than things - and advocated an encyclopedic education based on the Greek and Latin writers of a practical and scientific tendency (Aristotle, Theophrastus, Cato, Varro, Vitruvius, Seneca, and others). He outlined a plan for the establishment of an institution to be known by the classical (and Shakespearian) name "Academy" - a plan destined to have a great effect on education in the direction indicated by the friends of pansophia.

In this same year Robert Boyle, then an eager student of eighteen just returned to England from residence abroad, came under the influence of the 
genial Hartlib. In 1646 he writes his tutor inquiring about books on methods of husbandry and referring to the new philosophical college, which valued no knowledge but as it had a tendency to use. A few months later he was in correspondence with Hartlib in reference to the Invisible College, and had written a third friend that the corner-stones of the invisible, or, as they termed themselves, the philosophical college, did now and then honor him with their company. These philosophers whom Boyle entertained, and whose scientific acumen, breadth of mind, humility, and universal good-will he found so congenial, were the nucleus of the Royal Society of London, of which, on its definite organization in 1662, he was the foremost member. They had begun to meet together in London about 1645 , worthy persons inquisitive into natural philosophy - Wilkins, interested in the navigation of the air and of waters below the surface; Wallis, mathematician and grammarian; the many-sided Petty, political economist, and inventor of a double-bottomed boat, who had as a youth of twenty studied with Hobbes in Paris in 1643, and in 1648 was to write his first treatise on industrial education at the suggestion of Hartlib, and finally make a survey of Ireland and acquire large estates; Foster, professor of astronomy at Gresham College; Theodore Haak from the Pfalz; a number of medical men, Dr. Merret, Dr. Ent, a friend of Harvey, Dr. Goddard, who could always be relied upon to undertake an experiment, Dr. Glisson, the physiologist, author in 1654 of a treatise on the liver ( $D e$ Hepate), and others. They met once a week at Goddard's in Wood Street, at the Bull's Head Tavern in Cheapside, and at Gresham College. 
Dr. Wilkins, the brother-in-law of Cromwell, who is regarded by some as the founder of the Royal Society, removed to Oxford, as Warden of Wadham, in 1649. Here he held meetings and conducted experiments in conjunction with Wallis, Goddard, Petty, Boyle, and others, including Ward (afterwards Bishop of Salisbury) interested in Bulliau's Astronomy; and the celebrated physician and anatomist, Thomas Willis, author of a work on the brain ( $\mathrm{Ce}$ rebri Anatome), and another on fevers (De Febribus), in which he described epidemic typhoid as it occurred during the Civil War in 1643.

In the mean time the weekly meetings in London continued, and were attended when convenient by members of the Oxford group. At Gresham College by 1558 it was the custom to remain for discussion Wednesdays and Thursdays after Mr. Wren's lecture and Mr. Rooke's. During the unsettled state of the country after. Cromwell's death there was some interruption of the meetings, but with the accession of Charles II in 1660 there came a greater sense of security. New names appear on the records, Lord Brouncker, Sir Robert Moray, John Evelyn, Brereton, Ball, Robert Hooke, and Abraham Cowley.

Plans were discussed for a more permanent form of organization, especially on November 28, 1660, when something was said of a design to found a college for the promotion of physico-mathematical experimental learning. A few months later was published Cowley's proposition for an endowed college with twenty professors, four of whom should be constantly traveling in the interests of science. The sixteen resident professors "should be bound to study 


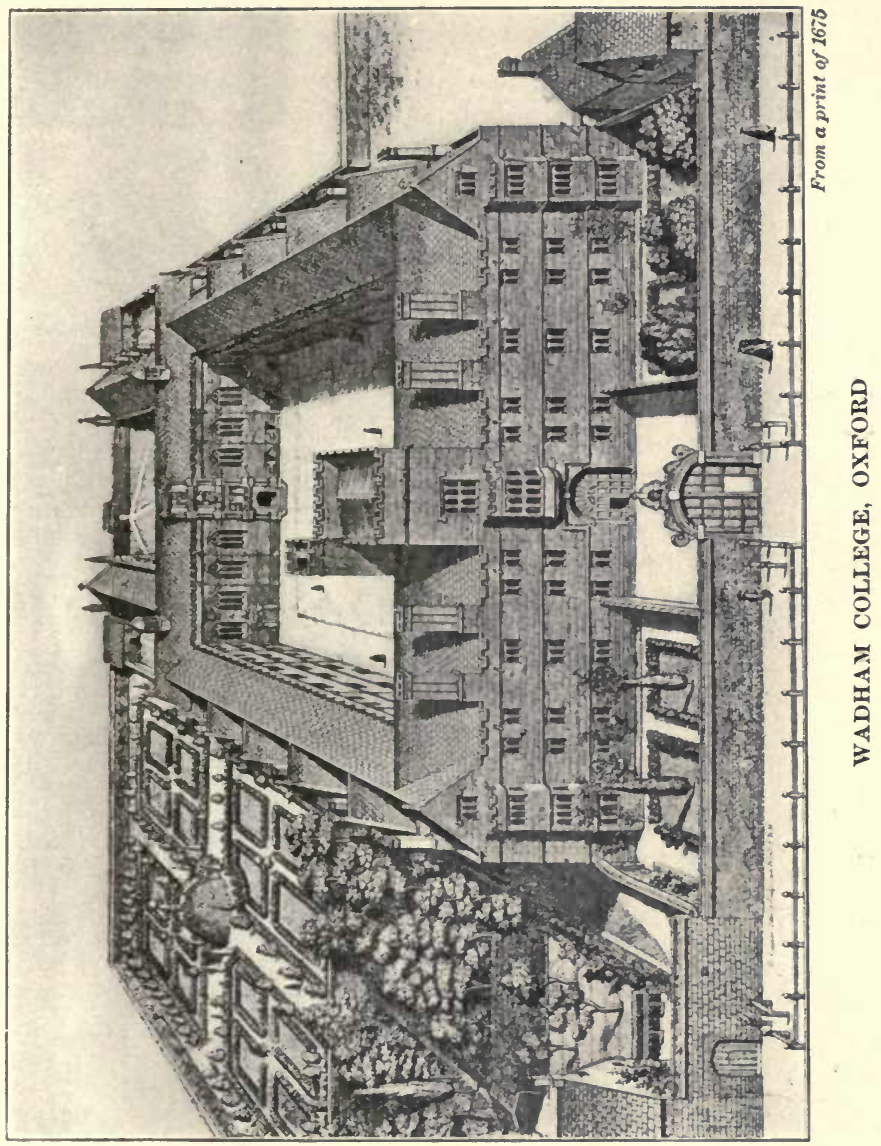



and teach all sorts of natural, experimental philosophy, to consist of the mathematics, mechanies, medicine, anatomy, chemistry, the history of animals, plants, minerals, elements, etc.; agriculture, architecture, art military, navigation, gardening; the mysteries of all trades and improvement of them; the facture of all merchandise, all natural magic or divination; and briefly all things contained in the Catalogue of Natural Histories annexed to my Lord Bacon's Organon." The early official history of the Royal Society (Sprat, 1667) says that this proposal hastened very much the adoption of a plan of organization. Cowley wished to educate youth and incur great expense $(£ 4,000)$, but "most of the other particulars of his draught the Royal Society is now putting in practice."

A charter of incorporation was granted in July, 1662; and, later, Charles II proclaimed himself founder and patron of the Royal Society for the advancement of natural science. Charles continued to take an interest in this organization, devoted to the discovery of truth by the corporate action of men; he proposed subjects for investigation, and asked their coöperation in a more accurate measurement of a degree of latitude. He showed himself tactful to take account of the democratic spirit of scientific investigation, and recommended to the Royal Society John Graunt, the author of a work on mortality statistics first published in 1661. Graunt was a shopkeeper of London, and Charles said that if they found any more such tradesmen, they should be sure to admit them all without more ado.

It was a recognized principle of the Society freely 
to admit men of different religions, countries, professions. Sprat said that they openly professed, not to lay the foundation of an English, Scotch, Irish, Popish or Protestant philosophy, but a philosophy of mankind. They sought (hating war as most of them did) to establish a universal culture, or, as they phrased it, a constant intelligence throughout all civil nations. Even for the special purposes of the Society, hospitality toward all nations was necessary; for the ideal scientist, the perfect philosopher, should have the diligence and inquisitiveness of the northern nations, and the cold and circumspect and wary disposition of the Italians and Spaniards. Haak from the German Palatinate was one of the earliest Fellows of the Society, and is even credited by Wallis with being the first to suggest the meetings of 1645 . Oldenburg from Bremen acted as secretary (along with Wilkins) and carried on an extensive foreign correspondence. Huygens of Holland was one of the original Fellows in 1663, while the names of Auzout, Sorbière, the Duke of Brunswick, Bulliau, Cassini, Malpighi, Leibnitz, Leeuwenhoek (as well as Winthrop and Roger Williams) appear in the records of the Society within the first decade. It seemed fitting that this cosmopolitan organization should be located in the world's metropolis rather than in a mere university town. Sprat thought London the natural seat of a universal philosophy.

As already implied, the Royal Society was not exclusive in its attitude toward the different vocations. A spirit of true fellowship prevailed in Gresham College, as the Society was sometimes called. The medical profession, the universities, the churches, the 
court, the army, the navy, trade, agriculture, and other industries were there represented. Social partition walls were broken down, and the Fellows, sobered by years of political and religious strife, joined, mutually assisting one another, in the advance of science for the sake of the common weal. Their express purpose was the improvement of all professions from the highest general to the lowest artisan. Particular attention was paid to the trades, the mechanic arts, and the fostering of inventions. One of their eight committees dealt with the histories of trades; another was concerned with mechanical inventions, and the king ordained in 1662 that no mechanical device should receive a patent before undergoing their scrutiny. A great many inventions emanated from the Fellows themselves - Hooke's hygroscope; Boyle's hydrometer, of use in the detection of counterfeit coin; and, again, the tablet anemometer used by Sir Christopher Wren (the Leonardo da Vinci of his age) to register the velocity of the wind. A third committee devoted itself to agriculture, and in the Society's museum were collected products and curiosities of the shop, mine, sea, etc. One Fellow advised that attention should be paid even to the least and plainest of phenomena, as otherwise they might learn the romance of nature rather than its true history. So bent were they on preserving a spirit of simplicity and straightforwardness that in their sober discussions they sought to employ the language of artisans, countrymen, and merchants rather than that of wits and scholars.

Of course there was in the Society a predominance of gentlemen of means and leisure, "free and uncon- 
fined." Their presence was thought to serve a double purpose. It checked the tendency to sacrifice the search of truth to immediate profit, and to lay such emphasis on application, as, in the words of a subsequent president of the Society, would make truth, and wisdom, and knowledge of no importance for their own sakes. In the second place their presence was held to check dogmatism on the part of the leaders, and subservience on the part of their followers. They understood how difficult it is to transmit knowledge without putting initiative in jeopardy and that quiet intellect is easily dismayed in the presence of bold speech. The Society accepted the authority of no one, and adopted as its motto $\mathrm{Nul}$ lius in Verba.

In this attitude they were aided by their subject and method. Search for scientific truth by laboratory procedure does not favor dogmatism. The early meetings were taken up with experiments and dis. cussions. The Fellows recognized that the mental powers are raised to a higher degree in company than in solitude. They welcomed diversity of view and the common-sense judgment of the onlooker. As in the Civil War the private citizen had held his own with the professional soldier, so here the contribution of the amateur to the discussion was not to be despised. They had been taught to shun all forms of narrowness and intolerance. They wished to avoid the pedantry of the mere scholar, and the allied states of mind to which all individuals are liable; they valued the concurring testimony of the well-informed assembly. In the investigation of truth by the experimental method they even arrived at the 
view that "true experimenting has this one thing inseparable from it, never to be a fixed and settled art, and never to be limited by constant rules." In its incipience at least it is evident that the Royal Society was filled with the spirit of tolerance and coöperation, and was singularly free from the spirit of envy and faction.

Not least important of the joint labors of the Society were its publications, which established contacts and stimulated research throughout the scientific world. Besides the Philosophical Transactions, which, since their first appearance in 1665 , are the most important source of information concerning the development of modern science, the Royal Society printed many important works, among which the following will indicate its early achievements :-

Hooke, Robert, Micrographia: or some Physiological Descriptions of Minute Bodies made by Magnifying Glasses. 1665.

Graunt, John, Natural and Political Observations... made upon the Bills of Mortality, with reference to the Government, Religion, Trade, Growth, Air, Diseases, and the several changes of the City. 3d edition, 1665.

Sprat, Thomas, The History of the Royal Society of London, for the Improving of Natural Knowledge. 1667. Malpighi, Marcello, Dissertatio epistolica de Bombyce; Societati Regice Londini dicata. 1669. (On the silkworm.)

Evelyn, John, Sylva, or a Discourse of Forest Trees. 1670. Horrocks, Jeremiah, Opera [Astronomica] postuma. 1673. Malpighi, Marcello, Anatome Plantarum. 1675.

Willughby, Francis, Ornithology (revised by John Ray). 1676.

Evelyn, John, A Philosophical Discourse of Earth, relating to the Culture and Improvement of it for Vegetation. 1676.

Grew, Nehemiah, The Anatomy of Plants. 1682. 
Willughby, F., Historia Piscium. 1686. Ray, John, Historia Plantarum. 2 vols., 1686-88. Flamsteed, John, Tide-Table for $168 \%$.

Newton, Isaac, Philosophice Naturalis Principia Mathematica. Autore Is. Newton. Imprimatur: S. Pepys, Reg. Soc. Præses. Julii 5, 1686. 4to. Londini, 1687.

After the Society had ordered that Newton's Mathematical Principles of Natural Philosophy should be printed, it was found that the funds had been exhausted by the publication of Willughby's book on fishes. It was accordingly agreed that Halley should undertake the business of looking after it, and printing it at his own charge, which he had engaged to do. Shortly after, the President of the Royal Society, Mr. Samuel Pepys, was desired to license Mr. Newton's book.

It was not merely by defraying the expense of publication that Halley contributed to the success of the Principia. He, Wren, Hooke, and other Fellows of the Royal Society, concluded in $\mathbf{1 6 8 4}$ that if Kepler's third law were true, then the attraction exerted on the different planets would vary inversely as the square of the distance. What, then, would be the orbit of a planet under a central attraction varying as the inverse square of the distance? Halley found that Newton had already determined that the form of the orbit would be an ellipse. Newton had been occupied with the problem of gravitation for about eighteen years, but until Halley induced him to do so, had hesitated, on account of certain unsettled points, to publish his results.

He writes: "I began (1666) to think of gravity extending to the orb of the moon, .... and thereby 


\section{COÖPERATION IN SCIENCE}

compared the force requisite to keep the moon in her orb with the force of gravity at the surface of the earth, and found them answer pretty nearly." As early as March of that same year Hooke had communicated to the Society an account of experiments in reference to the force of gravity at different distances from the surface of the earth, either upwards or downwards. At this and at every point in Newton's discovery the records of co-workers are to be found.

By Flamsteed, the first Royal Astronomer, were supplied more accurate data for the determination of planetary orbits. To Huygens Newton was indebted for the laws of centrifugal force. Two doubts had made his meticulous mind pause - one, of the accuracy of the data in reference to the measurement of the meridian, another, of the attraction of a spherical shell upon an external point. In the first matter the Royal Society, as we have seen, had been long interested, and Picard, who had worked on the measurement of the earth under the auspices of the Académie des Sciences, brought his results, which came to the attention of Newton, before the Royal Society in 1672. The second difficulty was solved by Newton himself in 1685 , when he proved that a series of concentric spherical shells would act on an external point as if their mass were concentrated at the center. For his calculations henceforth the planets and stars, comets and all other bodies are points acted on by lines of force, and " Every particle of matter in the universe attracts every other particle with a force varying inversely as the square of their mutual distances, and directly as the mass of the 
attracting particle." He deduced from this law that the earth must be flattened at the poles; he determined the orbit of the moon and of comets; he explained the precession of the equinoxes, the semidiurnal tides, the ratio of the mass of the moon and the earth, of the sun and the earth, etc. No wonder that Laplace considered that Newton's Principia was assured a preëminence above all the other productions of the human intellect. It is no detraction from Newton's merit to say that Halley, Hooke, Wren, Huygens, Bulliau, Picard, and many other contemporaries (not to mention Kepler and his predecessors), as well as the organizations in which they were units, share the glory of the result which they coöperated to achieve. On the contrary, he seems much more conspicuous in the social firmament because, in spite of the austerity and seeming independence of his genius, he formed part of a system, and was under its law.

Shortly after the founding of the Royal Society, correspondence, for which a committee was appointed, had been adopted as a means of gaining the coöperation of men and societies elsewhere. Sir John Moray, as President, wrote to Monsieur de Monmort, around whom, after the death of Mersenne, the scientific coterie in Paris had gathered. This group of men, which toward the close of the seventeenth century regarded itself, not unnaturally, as the parent society, was in 1666 definitely organized as the Académie Royale des Sciences. Finally, Leibnitz, who had been a Fellow of the Royal Society as early as 1673 , and had spent years in the service of the Dukes of Brunswick, was instrumental in the estab- 


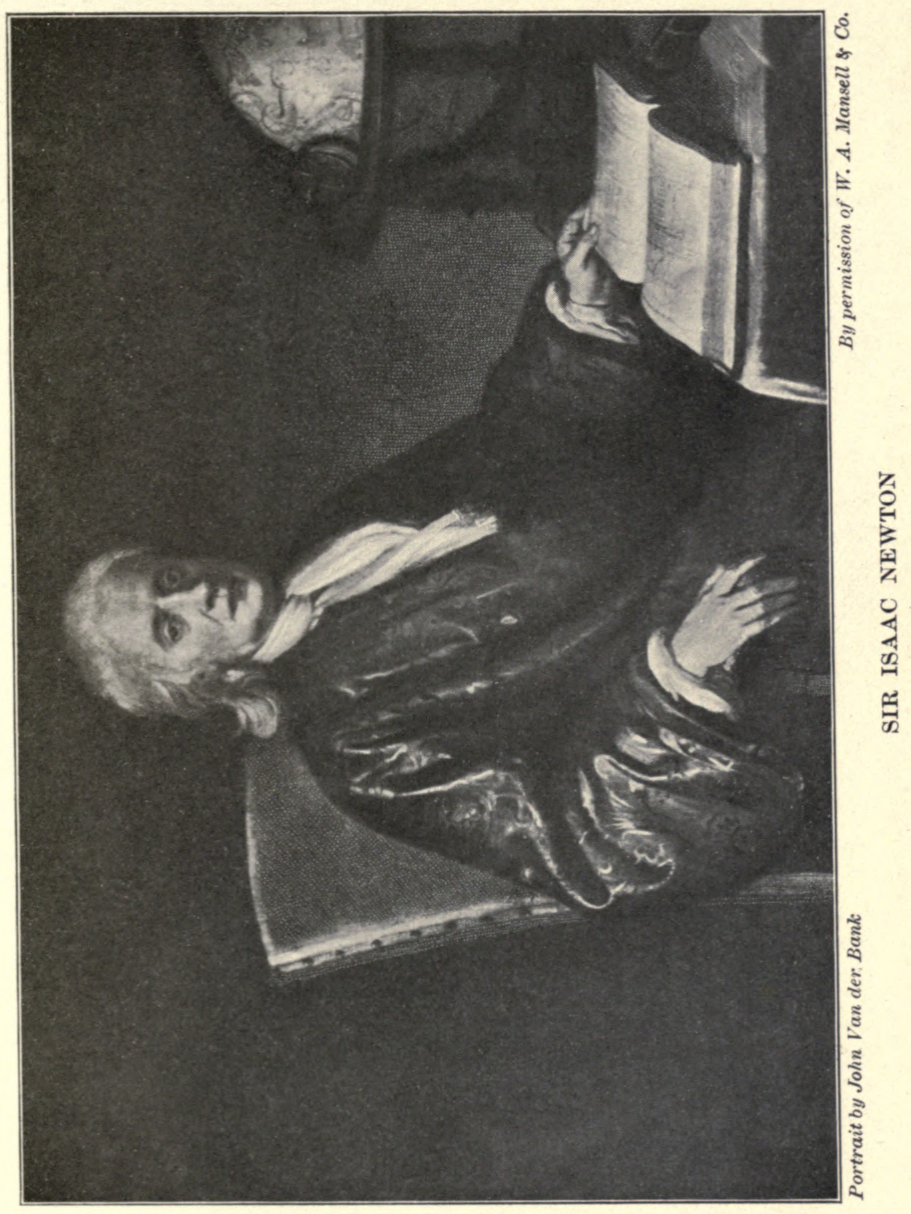





\section{COÖPERATION IN SCIENCE}

lishment in $\mathbf{1 7 0 0}$ of the Prussian Akademie der Wissenschaften at Berlin.

\section{REFERENCES}

Sir David Brewster, Memoirs of Sir Isaac Newton.

E. Conradi, Learned Societies and Academies in Early Times, Pedagogical Seminary, vol. xII (1905), pp. 384-426.

Abraham Cowley, A Proposition for the Advancement of Experimental Philosophy.

D. Masson, Life of Milton. Vol. III, chap. II.

Thomas Sprat, The History of the Royal Society of London.

The Record of the Royal Society (third edition, 1912). 


\section{CHAPTER IX}

SCIENCE AND THE STRUGGLE FOR LIBERTY BENJAMIN FRANKLIN

OF the Fellows of the Royal Society, Benjamin Franklin (1706-1790) is the most representative of that age of enlightenment which had its origin in Newton's Principia. Franklin represents the eighteenth century in his steadfast pursuit of intellectual, social, and political emancipation. And in his long fight, calmly waged, against the forces of want, superstition, and intolerance, such as still hamper the development of aspiring youth in America, England, and elsewhere, he found science no mean ally.

There is some reason for believing that the Franklins (francus - free) were of a free line, free from that vassalage to an overiord, which in the different countries of Europe did not cease to exist with the Middle Ages. For hundreds of years they had lived obscurely near Northampton. They had early joined the revolt against the papal authority. For generations they were blacksmiths and husbandmen. Franklin's great-grandfather had been imprisoned for writing satirical verses about some provincial magnate. Of the grandfather's four sons the eldest became a smith, but having some ingenuity and scholarly ability turned conveyancer, and was recognized as able and public-spirited. The other three were dyers. Franklin's father. Josiah and his Uncle Benjamin were nonconformists, and conceived the plan of emi- 
grating to America in order to enjoy their way of religion with freedom.

Benjamin, born at Boston, twenty-one years after his father's emigration, was the youngest of ten sons, all of whom were eventually apprenticed to trades. The father was a man of sound judgment who encouraged sensible conversation in his home. Uncle Benjamin, who did not emigrate till much later, showed interest in his precocious namesake. Both he and the maternal grandfather expressed in verse dislike of war and intolerance, the one with considerable literary skill, the other with a good deal of decent plainness and manly freedom, as his grandson said.

Benjamin was intended as a tithe to the Church, but the plan was abandoned because of lack of means to send him to college. After one year at the Latin Grammar School, and one year at an arithmetic and writing school, for better or worse, his education of that sort ceased; and at the age of ten he began to assist in his father's occupation, now that of tallowchandler and soap-boiler. He wished to go to sea, and gave indications of leadership and enterprise. His father took him to visit the shops of joiners, bricklayers, turners, braziers, cutlers, and other artisans, thus stimulating in him a delight in handicraft. Finally, because of a bookish turn he had been exhibiting, the boy was bound apprentice to his brother James, who about 1720 began to publish the New England Courant, the fourth newspaper to be established in America.

Among the books early read by Benjamin Franklin were The Pilgrim's Progress, certain historical collections, a book on navigation, works of Protestant 
controversy, Plutarch's Lives, filled with the spirit of Greek freedom, Dr. Mather's Bonifacius, and Defoe's Essay on Projects. The last two seemed to give him a way of thinking, to adopt Franklin's phraseology, that had an influence on some of the principal events of his life. Defoe, an ardent nonconformist, educated in one of the Academies (established on Milton's model) and especially trained in English and current history, advocated among other projects a military academy, an academy for improving the vernacular, and an academy for women. He thought it barbarous that a civilized and Christian country should deny the advantages of learning to women. They should be brought to read books and especially history. Defoe could not think that God Almighty had made women so glorious, with souls capable of the same accomplishments with men, and all to be only stewards of our houses, cooks, and slaves.

Benjamin still had a hankering for the sea, but he recognized in the printing-office and access to books other means of escape from the narrowness of the Boston of 1720. Between him and another bookish boy, John Collins, arose an argument in reference to the education of women. The argument took the form of correspondence. Josiah Franklin's judicious criticism led Benjamin to undertake the well-known plan of developing his literary style.

Passing over his reading of the Spectator, however, it is remarkable how soon his mind sought out and assimilated its appropriate nourishment, Locke's Essay on the Human Understanding, which began the modern epoch in psychology; the Port Royal Logic, 
prepared by that brilliant group of noble Catholies about Pascal; the works of Locke's disciple Collins, whose Discourse on Freethinking appeared in 1713; the ethical writings (1708-1713) of Shaftesbury, who defended liberty and justice, and detested all persecution. A few pages of translation of Xenophon's Memorabilia gave him a hint as to Socrates' manner of discussion, and he made it his own, and avoided dogmatism.

Franklin rapidly became expert as a printer, and early contributed articles to the paper. His brother, however, to whom he had been bound apprentice for a period of nine years, humiliated and beat him. Benjamin thought that the harsh and tyrannical treatment he received at this time was the means of impressing him with that aversion to arbitrary power that stuck to him through his whole life. He had a strong desire to escape from his bondage, and, after five years of servitude, found the opportunity. James Franklin, on account of some offensive utterances in the New England Courant, was summoned before the Council and sent to jail for one month, during which time Benjamin, in charge of the paper, took the side of his brother and made bold to give the rulers some rubs. Later, James was forbidden to publish the paper without submitting to the supervision of the Secretary of the Province. To evade the difficulty the New England Courant was published in Benjamin's name, James announcing his own retirement. In fear that this subterfuge might be challenged, he gave Benjamin a discharge of his indentures, but at the same time signed with him a new secret contract. Fresh quarrels arose between the 
brothers, however, and Benjamin, knowing that the editor dared not plead before court the second contract, took upon himself to assert his freedom, a step which he later regretted as not dictated by the highest principle.

Unable to find other employment in Boston, condemned by his father's judgment in the matter of the contract, somewhat under public criticism also for his satirical vein and heterodoxy, Franklin determined to try his fortunes elsewhere. Thus, at the age of seventeen he made his escape from Boston.

Unable to find work in New York, he arrived after some difficulties in Philadelphia in October, 1723. He had brought no recommendations from Boston; his supply of money was reduced to one Dutch dollar and a shilling in copper. But he that hath a Trade hath an Estate (as Poor Richard says). His capital was his industry, his skill as a printer, his good-will, his shrewd powers of observation, his knowledge of books, and ability to write. Franklin, recognized as a promising young man by the Governor, Sir William Keith, as previously by Governor Burnet of New York, had a growing sense of personal freedom and self-reliance.

But increased freedom for those who deserve it means increased responsibility; for it implies the possibility of error. Franklin, intent above all on the wise conduct of life, was deeply perturbed in his nineteenth and twentieth years by a premature engagement, in which his ever-passionate nature had involved him, by his failure to pay over money collected for a friend, and by the unsettled state of his religious and ethical beliefs. Encouraged by Keith 


\section{THE STRUGGLE FOR LIBERTY 119}

to purchase the equipment for an independent printing-office, Franklin, though unable to gain his father's support for the project, went to London (for the ostensible purpose of selecting the stock) at the close of the year 1724 .

He remained in London a year and a half, working in two of the leading printing establishments of the metropolis, where his skill and reliability were soon prized. He found the English artisans of that time great guzzlers of beer, and influenced some of his co-workers to adopt his own more abstinent and hygienic habits of eating and drinking. About this time a book, Religion of Nature Delineated, by William Wollaston (great-grandfather of the scientist Wollaston) so roused Franklin's opposition that he wrote a reply, which he printed in pamphlet form before leaving London in 1726, and the composition of which he afterwards regretted.

He returned to Philadelphia in the employ of a Quaker merchant, on whose death he resumed work as printer under his former employer. He was given control of the office, undertook to make his own type, contrived a copper-plate press, the first in America, and printed paper money for New Jersey. The substance of some lectures in defense of Christianity, in courses endowed by the will of Robert Boyle, made Franklin a Deist. At the same time his views on moral questions were clarified, and he came to recognize that truth, sincerity, and integrity were of the utmost importance to the felicity of life. What he had attained by his own independent thought rendered him ultimately more careful rather than more reckless. He now set value on his own character, and resolved to preserve it. 
In 1727 , still only twenty-one, he drew together a number of young men in a sort of club, called the "Junto," for mutual benefit in business and for the discussion of morals, politics, and natural philosophy. They professed tolerance, benevolence, love of truth. They discussed the effect on business of the issue of paper money, various natural phenomena, and kept a sharp look-out for any encroachment on the rights of the people. It is not unnatural to find that in a year or two (1729), after Franklin and a friend had established a printing business of their own and acquired the Pennsylvania Gazette, the young politician championed the cause of the Massachusetts Assembly against the claims first put forward by Governor Burnet, and that he used spirited language referring to America as a nation and clime foreign to England.

In 1730 Franklin bought out his partner, and in the same year published dialogues in the Socratic manner in reference to virtue and pleasure, which show a rapid development in his general views. About the same time he married, restored the money that had long been owing, and formulated his ethical code and religious creed. He began in 1732 the Poor Richard Almanacks, said to offer in their homely wisdom the best course in existence in practical morals.

As early as 1729 Franklin had published a pamphlet on Paper Currency. It was a well-reasoned discussion on the relation of the issue of paper currency to rate of interest, land values, manufactures, population, and wages. The want of money discouraged laboring and handicraftsmen. One must con- 
sider the nature and value of money in general. This essay accomplished its purpose in the Assembly. It was the first of those contributions which, arising from Franklin's consideration of the social and industrial circumstances of the times, gained for him recognition as the first American economist. It was in the same spirit that in $\mathbf{1 7 5 1}$ he discussed the question of population after the passage of the British Act forbidding the erection or the operation of iron or steel mills in the colonies. Science for Franklin was no extraneous interest; he was all of a piece, and it was as a citizen of Philadelphia he wrote those essays that commanded the attention of Adam Smith, Malthus, and Turgot.

In 1731 he was instrumental in founding the first of those public libraries, which (along with a free press) have made American tradesmen and farmers as intelligent, in Franklin's judgment, as most gentlemen from other countries, and contributed to the spirit with which they defended their liberties. The diffusion of knowledge became so general in the colonies that in 1766 Franklin was able to tell the English legislators that the seeds of liberty were universally found there and that nothing could eradicate them. Franklin became clerk of the General Assembly and postmaster, improved the paving and lighting of the city streets, and established the first fire brigade and the first police force in America. Then in 1743 in the same spirit of public beneficence Franklin put forth his Proposal for Promoting Useful Knowledge among the British Plantations in America. It outlines his plan for the establishment of the American Philosophical Society. 
Correspondence had already been established with the Royal Society of London. It is not diffcult to see in Franklin the same spirit that had animated Hartlib, Boyle, Petty, ${ }^{1}$ Wilkins, and their friends one hundred years before. In fact, Franklin was the embodiment of that union of scientific ideas and practical skill in the industries that with them was merely a pious wish.

In this same year of 1743 an eclipse of the moon, which could not be seen at Philadelphia on account of a northeast storm, was yet visible at Boston, where the storm came, as Franklin learned from his brother, about an hour after the time of observation. Franklin, who knew something of fireplaces, explained the matter thus: "When $I$ have a fire in my chimney, there is a current of air constantly flowing from the door to the chimney, but the beginning of the motion was at the chimney." So in a mill-race, water stopped by a gate is like air in a calm. When the gate is raised, the water moves forward, but the motion, so to speak, runs backward. Thus the principle was established in meteorology that northeast storms arise to the southwest.

No doubt Franklin was not oblivious of the practical value of this discovery, for, as Sir Humphry Davy remarked, he in no instance exhibited that false dignity, by which philosophy is kept aloof from common applications. In fact, Franklin was rather apologetic in reference to the magic squares and

${ }^{1}$ Seo The Advice of W. P. to Mr. Samuel Hartlib for the Advancement of some Particular Parts of Learning, in which is advocated a Gymnasium Mechanicum or a College of Tradesmen with fellowships for experts. Petty wanted trade encyclopedias prepared, and hoped for inventions in abundance. 
circles, with which he sometimes amused his leisure, as a sort of ingenious trifling. At the very time that the question of the propagation of storms arose in his mind he had contrived the Pennsylvania fireplace, which was to achieve cheap, adequate, and uniform heating for American homes. His aspiration was for a free people, well sheltered, well fed, well clad, well instructed.

In 1747 Franklin made what is generally considered his chief contribution to science. One of his correspondents, Collinson (a Fellow of the Royal Society and a botanist interested in useful plants, through whom the vine was introduced into Virginia), had sent to the Library Company at Philadelphia one of the recently invented Leyden jars with instructions for its use. Franklin, who had already seen similar apparatus at Boston, and his friends, set to work experimenting. For months he had leisure for nothing else. In this sort of activity he had a spontaneous and irrepressible delight. By March, 1747, they felt that they had made discoveries, and in July, and subsequently, Franklin reported results to Collinson. He had observed that a pointed rod brought near the jar was much more efficacious than a blunt rod in drawing off the charge; also that if a pointed rod were attached to the jar, the charge would be thrown off, and accumulation of charge prevented. Franklin, moreover, found that the nature of the charges on the inside and on the outside of the glass was different. He spoke of one as plus and the other as minus. Again, "We say $B$ (and bodies like-circumstanced) is electricized positively; $A$ negatively." Dufay had 
recognized two sorts of electricity, obtained by rubbing a glass rod and a stick of resin, and had spoken of them as vitreous and resinous. For Franklin electricity was a single subtle fluid, and electrical manifestations were owing to the degree of its presence, to interruption or restoration of equilibrium.

His mind, however, was bent on the use, the applications, the inventions, to follow. He contrived an "electric jack driven by two Leyden jars and capable of carrying a large fowl with a motion fit for roasting before a fire." $\mathrm{He}$ also succeeded in driving an "automatic" wheel by electricity, but he regretted not being able to turn his discoveries to greater account.

He thought later - in 1748 - that there were many points of similarity between lightning and the spark from a Leyden jar, and suggested an experiment to test the identity of their natures. The suggestion was acted upon at Marly in France. An iron rod about forty feet long and sharp at the end was placed upright in the hope of drawing electricity from the storm-clouds. A man was instructed to watch for storm-clouds, and to touch a brass wire, attached to a glass bottle, to the rod. The conditions seemed favorable May 10, 1752 ; sparks between the wire and rod and a "sulphurous" odor were perceived (the manifestations of wrath!). Franklin's well-known kite experiment followed. In 1753 he received from the Royal Society a medal for the identification and control of the forces of lightning ; subsequently he was elected Fellow, became a member of the Académie des Sciences, and of other learned bodies. By 1782 there were as many as four 
hundred lightning rods in use in Philadelphia alone, though some conservative people regarded their employment as impious. Franklin's good-will, clearness of conception, and common sense triumphed everywhere.

One has only to recall that in $\mathbf{1 7 5 3}$ he (along with Hunter) was in charge of the postal service of the colonies, that in $\mathbf{1 7 5 4}$ as delegate to the Albany Convention he drew up the first plan for colonial union, and that in the following year he furnished Braddock with transportation for the expedition against Fort Duquesne, to realize the distractions amid which he pursued science. In 1748 he had sold his printing establishment with the purpose of devoting himself to physical experiment, but the conditions of the time saved him from specialization.

In 1749 he drew up proposals relating to the education of youth in Pennsylvania, which led, two years later, to the establishment of the first American Academy. His plan was so advanced, so democratic, springing as it did from his own experience, that no secondary school has yet taken full advantage of its wisdom. The school, chartered in 1753, grew ultimately into the University of Pennsylvania. Moreover, it became the prototype of thousands of schools, which departed from the Latin Grammar Schools and the Colleges by the introduction of the sciences and practical studies into the curriculum.

Franklin deserves mention not only in connection with economics, meteorology, practical ethics, electricity, and pedagogy; his biographer enumerates nineteen sciences to which he made original contributions or which he advanced by intelligent criti- 
cism. In medicine he invented bifocal lenses and founded the first American public hospital ; in navigation he studied the Gulf Stream and waterspouts, and suggested the use of oil in storms and the construction of ships with water-tight compartments; in agriculture he experimented with plaster of Paris as a fertilizer and introduced in America the use of rhubarb; in chemistry he aided Priestley's experiments by information in reference to marsh gas. $\mathrm{He}$ foresaw the employment of air craft in war. Thinking the English slow to take up the interest in balloons, he wrote that we should not suffer pride to prevent our progress in science. Pride that dines on vanity sups on contempt, as Poor Richard says. When it was mentioned in his presence that birds fly in inclined planes, he launched a half sheet of paper to indicate that his previous observations had prepared his mind to respond readily to the discovery. His quickness and versatility made him sought after by the best intellects of Europe.

I pass over his analysis of mesmerism, his conception of light as dependent (like lightning) on a subtle fluid, his experiments with colored cloths, his view of the nature of epidemic colds, interest in inoculation for smallpox, in ventilation, vegetarianism, a stove to consume its own smoke, the steamboat, and his own inventions (clock, harmonica, etc.), for which he refused to take out patents.

However, from the many examples of his scientific acumen I select one more. As early as 1747 he had been interested in geology and had seen specimens of the fossil remains of marine shells from the strata of the highest parts of the Alleghany Moun- 
tains. Later he stated that either the sea had once stood at a higher level, or that these strata had been raised by the force of earthquakes. Such convulsions of nature are not wholly injurious, since, by bringing a great number of strata of different kinds to day, they have rendered the earth more fit for use, more capable of being to mankind a convenient and comfortable habitation. He thought it unlikely that a great bouleversement should happen if the earth were solid to the center. Rather the surface of the globe was a shell resting on a fluid of very great specific gravity, and was thus capable of being broken and disordered by violent movement. As late as 1788 Franklin wrote his queries and conjectures relating to magnetism and the theory of the earth. Did the earth become magnetic by the development of iron ore? Is not magnetism rather interplanetary and interstellar? May not the near passing of a comet of greater magnetic force than the earth have been a means of changing its poles and thereby wrecking and deranging its surface, and raising and depressing the sea level?

We are not here directly concerned with his political career, in his checking of governors and proprietaries, in his activities as the greatest of American diplomats, as the signer of the Declaration of Independence, of the Treaty of Versailles, and of the American Constitution, nor as the president of the Supreme Executive Council of Pennsylvania in his eightieth, eighty-first, and eighty-second years. When he was eighty-four, as president of the Society for Promoting the Abolition of Slavery, he signed a petition to Congress against that atrocious debase- 
ment of human nature, and six weeks later, within a few weeks of his death, defended the petition with his accustomed vigor, humor, wisdom, and ardent love of liberty. Turgot wittily summed up Franklin's career by saying that he had snatched the lightning from the heavens and the scepter from the hands of tyrants (eripuit colo fulmen sceptrumque tyrannis); for both his political and scientific activities sprang from the same impelling emotion hatred of the exercise of arbitrary power and desire for human welfare. It is no wonder that the French National Assembly, promulgators of the Rights of Man, paused in their labors to pay homage to the simple citizen, who, representing America in Paris from his seventy-first till his eightieth year, had by his wisdom and urbanity illustrated the best fruits of an instructed democracy.

\section{REFERENCES}

American Philosophical Society, Record of the Celebration of the Two Hundredth Anniversary of the Birth of Benjamin Franklin. S. G. Fisher, The True Benjamin Franklin.

Paul L. Ford, Many-sided Franklin.

Benjamin Franklin, Complete Works, edited by A. H. Smyth, ten volumes, vol. $\mathrm{x}$ containing biography. 


\section{CHAPTER $\mathrm{X}$}

THE INTERACTION OF THE SCIENCES - WERNER, HUTTON, BLACK, HALL, WILLIAM SMITH

The view expressed by Franklin regarding the existence of a fiery mass underlying the crust of the earth was not in his time universally accepted. In fact, it was a question very vigorously disputed what part the internal or volcanic fire played in the formation and modification of rock masses. Divergent views were represented by men who had come to the study of geology with varying aims and diverse scientific schooling, and the advance of the science of the earth's crust was owing in no small measure to the interaction of the different sciences which the exponents of the various points of view brought to bear.

Abraham Gottlob Werner (1750-1817) was the most conspicuous and influential champion on the side of the argument opposed to the acceptance of volcanic action as one of the chief causes of geologic formations. He was born in Saxony and came of a family which had engaged for three hundred years in mining and metal working. They were active in Saxony when George Agricola prepared his famous works on metallurgy and mineralogy inspired by the traditional wisdom of the local iron industry. Werner's father was an overseer of iron-works, and furnished his son with mineral specimens as playthings before the child could pronounce their names. In 
1769 Werner was invited to attend the newly founded Bergakademie (School of Mines) at Freiberg. Three years later he went to the University of Leipzig, but, true to his first enthusiasm, wrote in $\mathbf{1 7 7 4}$ concerning the outward characteristics of minerals (Von den äusserlichen Kennzeichen der Fossilien). The next year he was recalled to Freiberg as teacher of mineralogy and curator of collections. He was intent on classification, and might be compared in that respect with the naturalist Buffon, or the botanist Linnæus. He knew that chemistry afforded a surer, but slower, procedure; his was a practical, intuitive, field method. He observed the color, the hardness, weight, fracture of minerals, and experienced the joy the youthful mind feels in rapid identification. He translated Cronstedt's book on mineralogy descriptive of the practical blow-pipe tests. After the identification of minerals, Werner was interested in their discovery, the location of deposits, their geographical distribution, and the relative positions of different kinds of rocks, especially the constant juxtaposition or superposition of one stratum in relation to another.

Werner was an eloquent, systematic teacher with great charm of manner. He kept in mind the practical purposes of mining, and soon people flocked to Freiberg to hear him from all the quarters of Europe. He had before long disciples in every land. He saw all phenomena from the standpoint of the geologist. $\mathrm{He}$ knew the medicinal, as well as the economic, value of minerals. He knew the relation of the soil to the rocks, and the effects of both on racial characteristics. Building-stone determines style of archi- 
tecture. Mountains and river-courses have bearing on military tactics. He turned his linguistic knowledge to account and furnished geology with a definite nomenclature. Alex. v. Humboldt, Robert Jameson, D'Aubuisson, Weiss (the teacher of Froebel), were among his students. Crystallography and mineralogy became the fashion. Goethe was among the enthusiasts, and philosophers like Schelling, under the spell of the new science, almost deified the physical universe.

Werner considered all rocks as having originated by crystallization, either chemical or mechanical, from an aqueous solution - a universal primitive ocean. He was a Neptunist, as opposed to the Vulcanists or Plutonists, who believed in the existence of a central fiery mass. Werner thought that the earth showed universal strata like the layers of an onion, the mountains being formed by erosion, subsidence, cavings-in. In his judgment granite was a primitive rock formed previous to animal and regetable life (hence without organic remains) by chemical precipitation. Silicious slate was formed later by mechanical crystallization. At this period organized fossils first appear. Sedimentary rocks, like old red sandstone, and, according to Werner, basalt, are in a third class. Drift, sand, rubble, boulders, come next; and finally volcanic products, like lava, ashes, pumice. He was quite positive that all basalt was of aqueous origin and of quite recent formation. This part of his teaching was soon challenged. $\mathrm{He}$ was truer to his own essential purposes in writing a valuable treatise on metalliferous veins (Die Neue Theorie der Erzgänge), but even there his general 
views are apparent, for he holds that veins are clefts filled in from above by crystallization from aqueous solution.

Before Werner had begun his teaching career at Freiberg, Desmarest, the French geologist, had made a special study of the basalts of Auvergne. As a mathematician he was able to make a trigonometrical survey of that district, and constructed a map showing the craters of volcanoes of different ages, the streams of lava following the river courses, and the relation of basalt to lava, scoria, ashes, and other recognized products of volcanic action. In 1788 he was made inspector-general of French manufactures, later superintendent of the porcelain works at Sèvres. He lived to the age of ninety, and whenever Neptunists would try to draw him into argument, the old man would simply say, "Go and see."

James Hutton (1726-1797), the illustrious Scotch geologist, had something of the same aversion to speculation that did not rest on evidence; though he was eminently a philosopher in the strictest sense of the word, as his three quarto volumes on the Principles of Knowledge bear witness. Hutton was well trained at Edinburgh in the High School and University. In a lecture on logic an illustrative reference to aqua regia turned his mind to the study of chemistry. He engaged in experiments, and ultimately made a fortune by a process for the manufacture of sal ammoniac from coal-soot. In the mean time he studied medicine at Edinburgh, Paris, and Leyden, and continued the pursuit of chemistry. Then, having inherited land in Berwickshire, he studied husbandry in Norfolk and took interest in the 


\section{INTERACTION OF THE SCIENCES 133}

surface of the land and water-courses ; later he pursued these studies in Flanders. During years of highly successful farming, during which Hutton introduced new methods in Berwickshire, he was interested in meteorology, and in geology as related to soils. In 1768, financially independent, Dr. Hutton retired to reside in Edinburgh.

He was very genial and sociable and was in close association with Adam Smith, the economist, and with Black, known in the history of chemistry in connection with carbonic acid, latent heat, and experiments in magnesia, quicklime, and other alkaline substances (1777). Playfair, professor of mathematics, and later of natural philosophy, was Hutton's disciple and intimate friend. In the distinguished company of the Royal Society of Edinburgh, established in 1782 , the founder of dynamic geology was stimulated by these and other distinguished men like William Robertson, Lord Kames, and Watt. The first volume of the Transactions contains his Theory of Rains, and the first statement of his famous Theory of the Earth. He was very broad-minded and enthusiastic and would rejoice in Watt's improvements of the steam engine or Cook's discoveries in the South Pacific. Without emphasizing his indebtedness to Horace-Bénédict de Saussure, physicist, geologist, meteorologist, botanist, who gave to Europeans an appreciation of the sublime in nature, nor dwelling further on the range of Hutton's studies in language, general physics, etc., it is already made evident that his mind was such as to afford comprehensiveness of view.

He expressed the wish to induce men who had 
sufficient knowledge of the particular branches of science, to employ their acquired talents in promoting general science, or knowledge of the great system, where ends and means are wisely adjusted in the constitution of the material universe. Philosophy, he says, is surely the ultimate end of human knowledge, or the object at which all sciences properly must aim. Sciences no doubt should promote the arts of life; but, he proceeds, what are all the arts of life, or all. the enjoyments of mere animal nature, compared with the art of human happiness, gained by education and brought to perfection by philosophy? Man must learn to know himself; he must see his station among created things; he must become a moral agent. But it is only by studying things in general that he may arrive at this perfection of his nature. "To philosophize, therefore, without proper science, is in vain; although it is not vain to pursue science, without proceeding to philosophy."

In the early part of 1785 Dr. Hutton presented his Theory of the Earth in ninety-six pages of perfectly lucid English. The globe is studied as a machine adapted to a certain end, namely, to provide a habitable world for plants, for animals, and, above all, for intellectual beings capable of the contemplation and the appreciation of order and harmony. Hutton's theory might be made plain by drawing an analogy between geological and meteorological activities. The rain descends on the earth ; streams and rivers bear it to the sea; the aqueous vapors, drawn from the sea, supply the clouds, and the circuit is complete. Similarly, the soil is formed from the overhanging mountains; it is washed as sediment into the 
sea ; it is elevated, after consolidation, into the overhanging mountains. The earth is more than a mechanism, it is an organism that repairs and restores itself in perpetuity. Thus Hutton explained the composition, dissolution, and restoration of land upon the globe on a general principle, even as Newton had brought a mass of details under the single law of gravitation.

Again, as Newton had widened man's conception of space, so Hutton (and Buffon) enlarged his conception of time. For the geologist did not undertake to explain the origin of things; he found no vestige of a beginning, - no prospect of an end; and at the same time he conjured up no hypothetical causes, no catastrophes, or sudden convulsions of nature; neither did he (like Werner) believe that phenomena now present, were once absent; but he undertook to explain all geological change by processes in action now as heretofore. Countless ages were requisite to form the soil of our smiling valleys, but "Time, which measures everything in our idea, and is often deficient to our schemes, is to nature endless and as nothing." The calcareous remains of marine animals in the solid body of the earth bear witness of a period to which no other species of chronology is able to remount.

Hutton's imagination, on the basis of what can be observed to-day, pictured the chemical and mechanical disintegration of the rocks; and saw ice-streams bearing huge granite boulders from the declivities of primitive and more gigantic Alps. He believed (as Desmarest) that rivulets and rivers have constructed, and are constructing, their own valley systems, and 
that the denudation ever in progress would be eventually fatal to the sustenance of plant and animal and man, if the earth were not a renewable organism, in which repair is correlative with waste.

All strata are sedimentary, consolidated at the bottom of the sea by the pressure of the water and by subterranean heat. How are strata raised from the ocean bed? By the same subterranean force that helped consolidate them. The power of heat for the expansion of bodies, is, says Hutton (possibly having in mind the steam engine), so far as we know, unlimited. We see liquid stone pouring from the crater of a lofty volcano and casting huge rocks into mid-air, and yet find it difficult to believe that Vesuvius and Etna themselves have been formed by volcanic action. The interior of the planet may be a fluid mass, melted, but unchanged by the action of heat. The volcanoes are spiracles or safety-valves, and are widely distributed on the surface of the earth.

Hutton believed that basalt, and the whinstones generally, are of igneous origin. Moreover, he put granite in the same category, and believed it had been injected, as also metalliferous veins, in liquid state into the stratified rocks. If his supposition were correct, then granite would be found sending out veins from its large masses to pierce the stratified rocks and to crop out where stratum meets stratum. His conjecture was corroborated at Glen Tilt (and in the island of Arran). Hutton was so elated at the verification of his view that the Scotch guides thought he had struck gold, or silver at the very least. In the bed of the river Tilt he could see at 
six points within half a mile powerful veins of red granite piercing the black micaceous schist and giving every indication of having been intruded from beneath, with great violence, into the earlier formation.

Hutton felt confirmed in his view that in nature there is wisdom, system, and consistency. Even the volcano and earthquale, instead of being accidents, or arbitiary manifestations of divine wrath, are part of the economy of nature, and the best clue we have to the stupendous force necessary to heave up the strata, inject veins of metals and igneous rocks, and insure a succession of habitable worlds.

In 1795 Dr. Hutton published a more elaborate statement of his theory in two volumes. In 1802 Playfair printed Illustrations of the Huttonian Theory, a simplification, having, naturally, littlo originality. Before his death in 1797 Hutton devoted his time to reading new volumes by Saussure on the Alps, and to preparing a book on The Elements of Agriculture.

Sir James Hall of Dunglass was a reluctant convert to Hutton's system of geology. Three arguments against the Huttonian hypothesis gave him cause for doubt. Would not matter solidifying after fusion form a glass, a vitreous, rather than a crystalline product? Why do basalts, whinstones, and other supposedly volcanic rocks differ so much in structure from lava? How can marble and other limestones have been fused, seeing that they are readily calcined by heat? Hutton thought that the compression under which the subterranean heat had been applied was a factor in the solution of these problems. He 
was encouraged in this view by Black, who, as already implied, had made a special study of limestone and had demonstrated that lime acquires its causticity through the expulsion of carbonic acid.

Hall conjectured in addition that the rate at which the fused mass cooled might have some bearing on the structure of igneous rocks. An accident in the Leith glass works strengthened the probability of his conjecture and encouraged him to experiment. A pot of green bottle-glass had been allowed to cool slowly with the result that it had a stony, rather a vitreous structure. Hall experimenting with glass could secure either structure at will by cooling rapidly or slowly, and that with the same specimen.

$\mathrm{He}$ later enclosed some fragments of whinstone in a black-lead crucible and subjected it to intense heat in the reverberating furnace of an iron foundry. (He was in consultation with Mr. Wedgwood on the scale of heat, and with Dr. Hope and Dr. Kennedy, chemists.) After boiling, and then cooling rapidly, the contents of the crucible proved a black glass. Hall repeated the experiment, and cooled more slowly. The result was an intermediate substance, neither glass nor whinstone - a sort of slag. Again he heated the crucible in the furnace, and removed quickly to an open fire, which was maintained some hours and then permitted to die out. The result in this case was a perfect whinstone. Similar results were obtained with regular basalts and different specimens of igneous rock.

Hall next experimented with lava from Vesuvius, Etna, Iceland, and elsewhere, and found that it behaved like whinstone. Dr. Kennedy by careful chem- 
ical analysis confirmed Hall's judgment of the similarity of these two igneous products.

Still later Hall introduced chalk and powdered limestone into porcelain tubes, gun barrels, and tubes bored in solid iron, which he sealed and brought to very high temperatures. He obtained, by fusion, a crystalline carbonate resembling marble. Under the high pressure in the tube the carbonic acid was retained. By these and other experiments this doubting disciple confirmed Hutton's theory, and became one of the great founders of experimental geology.

It remained for William Smith (1769-1839), surveyor and engineer, to develop that species of chronology that Hutton had ascribed to organic remains in the solid strata, to arrange these strata in the order of time, and thus to become the founder of historic geology. For this task his early education might at first glance seem inadequate. His only schooling was received in an elementary institution in Oxfordshire. He managed, however, to acquire some knowledge of geometry, and at eighteen entered, as assistant, a surveyor's office. He never attained any literary facility, and was always more successful in conveying his observations by maps, drawings, and conversation than by books.

However, he early began his collection of minerals and observed the relation of the soil and the vegetation to the underlying rocks. Engaged at the age of twenty-four in taking levelings for a canal, he noticed that the strata were not exactly horizontal, but dipped to the east "like slices of bread and butter," a phenomenon he considered of scientific significance. In connection with his calling he had an opportunity 
of traveling to the north of England and so extended the range of his observation, always exceptionally alert. For six years he was engaged, as engineer, in the construction of the Somerset Coal Canal, where he enlarged and turned to practical account his knowledge of strata.

Collectors of fossils (as Lamarck afterwards called organic remains) were surprised to find Smith able to tell in what formation their different specimens had been found, and still more when he enunciated the view that "whatever strata were to be found in any part of England the same remains would be found in it and no other." Moreover, the same order of superposition was constant among the strata, as Werner, of whom Smith knew nothing, had indeed taught. Smith was able to dictate a Tabular View of British Strata from coal to chalk with the char. acteristic fossils, establishing an order that was found to obtain on the Continent of Europe as well as in Britain.

He constructed geological maps of Somerset and fourteen other English counties, to which the attention of the Board of Agriculture was called. They showed the surface outcrops of strata, and were intended to be of assistance in mining, roadmaking, canal construction, draining, and water supply. It was at the time of William Smith's scientific discoveries that the public interest in canal transportation was at its height in England, and his study of the strata was a direct outcome of his professional activity. He called himself a mineral surveyor, and he traveled many thousand miles yearly in connection with his calling and his interest in the study of 
geology. In 1815 he completed an extensive geological map of England, on which all subsequent geological maps have been modeled. It took into account the collieries, mines, canals, marshes, fens, and the varieties of soil in relation to the substrata.

Later (1816-1819) Smith published four volumes, Strata Identified by Organized Fossils, which put on record some of his extensive observations. His mind was practical and little given to speculation. It does not lie in our province here to trace his influence on Cuvier and other scientists, but to add his name as a surveyor and engineer to the representatives of mineralogy, chemistry, physics, mathematics, philosophy, and various industries and vocations, which contributed to the early development of modern geology.

\section{REFERENCES}

Sir A. Geikie, Founders of Geology. James Hutton, Theory of the Earth. Sir Charles Lyell, Principles of Geology.

John Playfair, Illustrations of the Huttonian Theory. K. A. v. Zittel, History of Geology and Palcontology. 


\section{CHAPTER XI}

\section{SCIENCE AND RELIGION - KANT, LAMBERT,}

LAPLACE, SIR WILLIAM HERSCHEL

Hutron had advanced the study of geology by concentrating attention on the observable phenomena of the earth's crust, and turning away from speculations about the origin of the world and the relation of this sphere to other units of the cosmos. In the same century, however, other scientists and philosophers were attracted by these very problems which seemed not to promise immediate or demonstrative solution, and through their studies they arrived at conclusions which profoundly affected the science, the ethics, and the religion of the civilized world.

Whether religion be defined as a complex feeling of elation and humility - a sacred fear - akin to the æsthetic sense of the sublime; or, as an intellectual recognition of some high powers which govern us below - of some author of all things, of some force social or cosmic which tends to righteousness; or, as the outcrop of the moral life touched with light and radiant with enthusiasm ; or, as partaking of the nature of all these : it cannot be denied that the eighteenth century contributed to its clarification and formulation, especially through the efforts of the German philosopher, Immanuel Kant (17241804). Yet it is not difficult to show that the philosophy of Kant and of those associated with 
him was greatly influenced by the science of the time, and that, in fact, in his early life he was a scientist rather than a philosopher in the stricter sense. His General Natural History and Theory of the Heavens, written at the age of thirty-one, enables us to follow his transition from science to philosophy, and, more especially, to trace the influence of his theory of the origin of the heavenly bodies on his religious conceptions.

For part of this theory Kant was indebted to Thomas Wright of Durham (1711-1786). Wright was the son of a carpenter, became apprenticed to a watchmaker, went to sea, later became an engraver, a maker of mathematical instruments, rose to affluence, wrote a book on navigation, and was offered a professorship of navigation in the Imperial Academy of St. Petersburg. It was in 1750 that he published, in the form of nine letters, the work that stimulated the mind of Kant, An Original Theory or New Hypothesis of the Universe. The author thought that the revelation of the structure of the heavens naturally tended to propagate the principles of virtue and vindicate the laws of Providence. He regarded the universe as an infinity of worlds acted upon by an eternal Agent, and full of beings, tending through their various states to a final perfection. Who, conscious of this system, can avoid being filled with a kind of enthusiastic ambition to contribute his atom toward the due admiration of its great and Divine Author?

Wright discussed the nature of mathematical certainty and the various degrees of moral probability proper for conjecture (thus pointing to a distinction 
that ultimately became basal in the philosophy of Kant). When he claimed that the sun is a vast body of blazing matter, and that the most distant star is also a sun surrounded by a system of planets, he knew that he was reasoning by analogy and not enunciating what is immediately demonstrable. Yet this multitude of worlds opens out to us an immense field of probation and an endless scene of hope to ground our expectation of an ever future happiness upon, suitable to the native dignity of the awful Mind which made and comprehended it.

The most striking part of W right's Original Theory relates to the construction of the Milky Way, which he thought analogous in form to the rings of Saturn. From the center the arrangement of the systems and the harmony of the movements could be discerned, but our solar system occupies a section of the belt, and what we see of the creation gives but a confused picture, unless by an effort of imagination we attain the right point of view. The various cloudy stars or light appearances are nothing but a dense accumulation of stars. What less than infinity can circumscribe them, less than eternity comprehend them, or less than Omnipotence produce or support them? He passes on to a discussion of time and space with regard to the known objects of immensity and duration, and in the ninth letter says that, granting the creation to be circular or orbicular, we ean suppose in the center of the whole an intelligent principle, the to-all-extending eye of Providence, or, if the creation is real, and not merely ideal, a sphere of some sort. Around this the suns keep their orbits harmoniously, all apparent irregularities arising from 
our eccentric view. Moreover, space is sufficient for many such systems.

Kant resembled his predecessor in his recognition of the bearing on moral and religious conceptions of the study of the heavens and also in his treatment of many astronomical details, sometimes merely adopting, more frequently developing or modifying, the teachings of Wright. He held that the stars constitute a system just as much as do the planets of our solar system, and that other solar systems and other Milky Ways may have been produced in the boundless fields of space. Indeed, he is inclined to identify with the latter systems the small luminous elliptical areas in the heavens reported by Maupertuis in $\mathbf{1 7 4 2}$. Kant also accepted Wright's conjecture of a central sun or globe and even made selection of one of the stars to serve in that office, and taught that the stars consist like our sun of a fiery mass. One cannot contemplate the world-structure without recognizing the excellent orderliness of its arrangement, and perceiving the sure indications of the hand of God in the completeness of its relations. Reason, he says in the Allgemeine Naturgeschichte, refuses to believe it the work of chance. It must have been planned by supreme wisdom and carried into effect by Omnipotence.

Kant was especially stimulated by the analogy between the Milky Way and the rings of Saturn. Hedid not agree with Wright that they, or the cloudy areas, would prove to be stars or small satellites, but rather that both consisted of vapor particles. Giving full scope to his imagination, he asks if the earth as well as Saturn may not have been surrounded by a ring. 
Might not this ring explain the supercelestial waters that gave such cause for ingenuity to the medieval writers? Not only so, but, had such a vaporous ring broken and been precipitated to the earth, it would have caused a prolonged Deluge, and the subsequent rainbow in the heavens might very well have been interpreted as an allusion to the vanished ring, and as a promise. This, however, is not Kant's characteristic manner in supporting moral and religious truth.

To account for the origin of the solar system, the German philosopher assumes that at the beginning of all things the material of which the sun, planets, satellites, and comets consist, was uncompounded, in its primary elements, and filled the whole space in which the bodies formed out of it now revolve. This state of nature seemed to be the very simplest that could follow upon nothing. In a space filled in this way a state of rest could not last for more than a moment. The elements of a denser kind would, according to the law of gravitation, attract matter of less specific gravity. Repulsion, as well as attraction, plays a part among the particles of matter disseminated in space. Through it the direct fall of particles may be diverted into a circular movement about the center toward which they are gravitating.

Of course, in our system the center of attraction is the nucleus of the sun. The mass of this body increases rapidly, as also its power of attraction. Of the particles gravitating to it the heavier become heaped up in the center. In falling from different heights toward this common focus the particles cannot have such perfect equality of resistance that no 


\section{SCIENCE AND RELIGION}

lateral movements should be set up. A general circulatory motion is in fact established ultimately in one direction about the central mass, which receiving new particles from the encircling current rotates in harmony with it.

Mutual interference in the particles outside the mass of the sun prevents all accumulation except in one plane and that takes the form of a thin disk continuous with the sun's equator. In this circulating vaporous disk about the sun differences of density give rise to zones not unlike the rings of Saturn. These zones ultimately contract to form planets, and as the planets are thrown off from the central solar mass till an equilibrium is established between the centripetal and centrifugal forces, so the satellites in turn are formed from the planets. The comets are to be regarded as parts of the system, akin to the planets, but more remote from the control of the centripetal force of the sun. It is thus that Kant conceived the nebular hypothesis, accounting (through the formation of the heavenly bodies from a cloudy vapor similar to that still observable through the telescope) for the revolution of the planets in one direction about the sun; the rotation of sun and planets; the revolution and rotation of satellites; the comparative densities of the heavenly bodies; the materials in the tails of comets; the rings of Saturn, and other celestial phenomena. Newton, finding no matter between the planets to maintain the community of their movements, asserted that the immediate hand of God had instituted the arrangement without the intervention of the forces of Nature. His disciple Kant now undertook to explain an additional number of phenomena 
on mechanical principles. Granted the existence of matter, he felt capable of tracing the cosmic evolution, but at the same time he maintained and strengthened his religious position, and did not assume (like Democritus and Epicurus) eternal motion without a Creator or the coming together of atoms by accident or haphazard.

It might be objected, he says, that Nature is sufficient unto itself; but universal laws of the action of matter serve the plan of the Supreme Wisdom. There is convincing proof of the existence of God in the very fact that Nature, even in chaos, cannot proceed otherwise than regularly and according to law. Even in the essential properties of the elements that constituted the chaos, there could be traced the mark of that perfection which they have derived from their origin, their essential character being a consequence of the eternal idea of the Divine Intelligence. Matter, which appears to be merely passive and wanting in form and arrangement, has in its simplest state a tendency to fashion itself by a natural development into a more perfect constitution. Matter must be considered as created by God in accordance with law and as ever obedient to law, not as an independent or hostile force needing occasional correction. To suppose the material world not under law would be to believe in a blind fate rather than in Providence. It is Nature's harmony and order revealed to our understanding that give us a clue to its creation by an understanding of the highest order.

In a work written eight years later Kant sought to furnish people of ordinary intelligence with a proof of the existence of God. It might seem irrelevant in 
such a production to give an exposition of physical phenomena, but, intent on his method of mounting to a knowledge of God by means of natural science, he here repeats in summarized form his theory of the origin of the heavenly bodies. Moreover, the influence of his astronomical studies persisted in his maturest philosophy, as can be seen in the well-known passage at the conclusion of his ethical work, the Critique of the Practical Reason (1788): "There are two things that fill my spirit with ever new and increasing awe and reverence - the more frequently and the more intently I contemplate them - the starstrewn sky above me and the moral law within." His religious and ethical conceptions were closely associated with - indeed, dependent upon - an orderly and infinite physical universe.

In the mathematician, astronomer, physicist, and philosopher, J. H. Lambert (1728-1777), Kant found a genius akin to his own, and through him hoped for a reformation of philosophy on the basis of the study of science. Lambert like his contemporary was a disciple of Newton, and in 1761 he published a book in the form of letters expressing views in reference to the Milky Way, fixed stars, central sun, very similar to those published by Kant in 1755. Lambert had heard of Wright's work, so similar to his own, a year after the latter was written.

Comets, now robbed of many of the terrors with which ancient superstition endowed them, might, he says, seem to threaten catastrophe, by colliding with the planets or by carrying off a satellite. But the same hand which has cast the celestial spheres in space, has traced their course in the heavens, and 
does not allow them to wander at random to distur b and destroy each other. Lambert imagines that all these bodies have exactly the volume, weight, position, direction, and speed necessary for the avoidance of collisions. If we confess a Supreme Ruler who brought order from chaos, and gave form to the universe; it follows that this universe is a perfect work, the impress, picture, reflex of its Creator's perfection. Nothing is left to blind chance. Means are fitted to ends. There is order throughout, and in this order the dust beneath our feet, the stars above our heads, atoms and worlds, are alike comprehended.

Laplace in his statement of the nebular hypothesis made no mention of Kant. He sets forth, in the Exposition of the Solar System, the astronomical data that the theory is designed to explain : the movements of the planets in the same direction and almost in the same plane; the movements of the satellites in the same direction as those of the planets; the rotation of these different bodies and of the sun in the same direction as their projection, and in planes little different; the small eccentricity of the orbits of planets and satellites; the great eccentricity of the orbits of comets. How on the ground of these data are we to arrive at the cause of the earliest movements of the planetary system?

A fluid of immense extent must be assumed, embracing all these bodies. It must have circulated about the sun like an atmosphere and, in virtue of the excessive heat which was engendered, it may be assumed that this atmosphere originally extended beyond the orbits of all the planets, and was con- 
tracted by stages to its present form. In its primitive state the sun resembled the nebulæ, which are to be observed through the telescope, with fiery centers and cloudy periphery. One can imagine a more and more diffuse state of the nebulous matter.

Planets were formed, in the plane of the equator and at the successive limits of the nebulous atmosphere, by the condensation of the different zones which it abandoned as it cooled and contracted. The force of gravity and the centrifugal force sufficed to maintain in its orbit each successive planet. From the cooling and contracting masses that were to constitute the planets smaller zones and rings were formed. In the case of Saturn there was such regularity in the rings that the annular form was maintained; as a rule from the zones abandoned by the planet-mass satellites resulted. Differences of temperature and density of the parts of the original mass account for the eccentricity of orbits, and deviations from the plane of the equator.

In his Celestial Mechanics (1825) Laplace states that, according to Herschel's observations, Saturn's rotation is slightly quicker than that of its rings. This seemed a confirmation of the hypothesis of the Exposition du Système du Monde.

When Laplace presented the first edition of this earlier work to Napoleon, the First Consul said : "Newton has spoken of God in his book. I have already gone through yours, and I have not found that name in it a single time." To this Laplace is said to have replied: "First Citizen Consul, I have not had need of that hypothesis." The astronomer did not, however, profess atheism; like Kant he felt 
competent to explain on mechanical principles the development of the solar system from the point at which he undertook it. In his later years he desired that the misleading anecdote should be suppressed. So far was he from self-sufficiency and dogmatism that his last utterance proclaimed the limitations of even the greatest intellects: "What we know is little enough, what we don't know is immense" (Ce que nous connaissons est peu de chose, ce que nous ignorons est immense).

Sir William Herschel's observations, extended over many years, confirmed both the nebular hypothesis and the theory of the systematic arrangement of the stars. He made use of telescopes 20 and 40 feet in focal length, and of 18.7 and 48 inches aperture, and was thereby enabled, as Humboldt said, to sink a plummet amid the fixed stars, or, in his own phrase, to gauge the heavens. The Construction of the Heavens was always the ultimate object of his observations. In a contribution on this subject submitted to the Royal Society in $\mathbf{1 7 8 7}$ he announced the discovery of 466 new nebulæ and clusters of stars. The sidereal heavens are not to be regarded as the concave surface of a sphere, from the center of which the observer might be supposed to look, but rather as resembling a rich extent of ground or chains of mountains in which the geologist discovers many strata consisting of various materials. The Milky Way is one stratum and in it our sun is placed, though perhaps not in the very center of its thickness.

By 1811 he had greatly increased his observations of the nebulæ and could arrange them in series differ- 
ing in extent, condensation, brightness, general form, possession of nuclei, situation, and in resemblance to comets and to stars. They ranged from a faint trace of extensive diffuse nebulosity to a nebulous star with a mere vestige of cloudiness. Herschel was able to make the series so complete that the difference between the members was no more than could be found in a series of pictures of the human figure taken from the birth of a child till he comes to be a man in his prime. The difference between the diffuse nebulous matter and the star is so striking that the idea of conversion from one to the other would hardly occur to any one without evidence of the intermediate steps. It is highly probable that each successive state is the result of the action of gravity.

In his last statement, 1818 , he admitted that to his telescopes the Milky Way had proved fathomless, but on " either side of this assemblage of stars, presumably in ceaseless motion round their common center of gravity, Herschel discovered a canopy of discrete nebulous masses, such as those from the condensation of which he supposed the whole stellar universe to be formed."

In the theory of the evolution of the heavenly bodies, as set forth by Kant, Laplace, and Herschel, it was assumed that the elements that composed the earth are also to be found elsewhere throughout the solar system and the universe. The validity of this assumption was finally established by spectrum analysis. But this vindication was in part anticipated, at the beginning of the nineteenth century, by the analysis of meteorites. In these were found large quantities of iron, considerable percentages of nickel, as well as 
cobalt, copper, silicon, phosphorus, carbon, magnesium, zinc, and manganese.

\section{REFERENCES}

G. F. Becker, Kant as a Natural Philosopher, American Journal of Science, vol. v (1898), pp. 97-112.

W. W. Bryant, A History of Astronomy.

Agnes M. Clerke, History of Astronomy during the Nineteenth Century.

Agnes M. Clerke, The Herschels and Modern Astronomy.

Sir William Herschel, Papers on the Construction of the Heavens (Philosophical Transactions, 1784, 1811, etc.).

A. R. Hinks, Astronomy (Home University Library).

E. W. Maunders, The Science of the Stars (The People's Books). 


\section{CHAPTER XII}

THE REIGN OF LAW - DALTON, JOULE

IN the middle of the eighteenth century, when Lambert and Kant were recognizing system and design in the heavens, little progress had been made toward discovering the constitution of matter or revealing the laws of the hidden motions of things. Boyle had, indeed, made a beginning, not only by his study of the elasticity of the air, but by his distinction of the elements and compounds and his definition of chemistry as the science of the composition of substances. How little had been accomplished, however, is evident from the fact that in $\mathbf{1 7 5 0}$ the so-called elements - earth, air, fire, water - which Bacon had marked for examination in 1620 , were still unanalyzed, and that no advance had been made beyond his conception of the nature of heat, the majority, indeed, of the learned world holding that heat is a substance (variously identified with sulphur, carbon, or hydrogen) rather than a mode of motion.

How scientific thought succeeded in bringing order out of confusion and chaos in the subsequent one hundred years, and especially at the beginning of the nineteenth century, can well be illustrated by these very matters, the study of combustion, of heat as a form of energy, of the constituents of the atmosphere, and of the chemistry of water and of the earth.

Reference has already been made to Black's discovery of carbonic acid, and of the phenomena which 
he ascribed to latent heat. The first discovery (1754) was the result of the preparation of quicklime in the practice of medicine; the second (1761) involving experiments on the temperatures of melting ice, boiling water, and steam, stimulated Watt in his improvement of the steam engine. In 1766 Joseph Priestley began his study of airs, or gases. In the following year observation of work in a brewery roused his curiosity in reference to carbonic acid. In 1772 he experimented with nitric oxide. In the previous century Mayow had obtained nitric oxide by treating iron with nitric acid. $\mathrm{He}$ had then introduced this gas into ordinary air confined over water, and found that the mixture suffered a reduction of volume. Priestley applied this process to the analysis of common air, which he discovered to be complex and not simple. In 1774 , by heating red oxide of mercury by means of a burning-glass, he obtained a gas which supported combustion better than common air. He inhaled it, and experienced a sense of exhilaration. "Who can tell," he writes, " but in time this pure air may become a fashionable article in luxury? Hitherto only two mice and myself have had the privilege of breathing it."

The Swedish investigator Scheele had, however, discovered this same constituent of the air before 1773. He thought that the atmosphere must consist of at least two gases, and he proved that carbonic acid results from combustion and respiration. In 1772 the great French scientist Lavoisier found that sulphur, when burned, gains weight instead of losing weight, and five years later he concluded that air consists of two gases, one capable of absorption by 
burning bodies, the other incapable of supporting combustion. He called the first "oxygen." In his Elements of Chemistry Lavoisier gave a clear exposition of his system of chemistry and of the discoveries of other European chemists. After his studies the atmosphere was no longer regarded as mysterious and chaotic. It was known to consist largely of oxygen and nitrogen, and to contain in addition aqueous vapor, carbonic acid, and ammonia which might be brought to earth by rain.

Cavendish obtained nitrogen from air by using nitric oxide to remove the oxygen, and found that air consists of about seventy-nine per cent nitrogen and about twenty-one per cent oxygen. He also by use of the electric spark caused the oxygen and nitrogen of the air to unite to form nitric acid. When the nitrogen was exhausted and the redundant oxygen removed, "only a small bubble of air remained unabsorbed." Similarly Cavendish had found that water results from the combination of oxygen and hydrogen. Watt had likewise held that water is not an element, but a compound of two elementary substances. Thus the great masses, - earth, air, fire, water, - assumed as simple by many philosophers from the earliest times, were resolving into their constituent parts. At the same time other problems were demanding solution. What are the laws of chemical combination? What is the relation of heat to other forms of energy? To the answering of these questions (as of those from which these grew) the great manufacturing centers contributed, and no city more potently than Manchester through Dalton and his pupil and follower Joule. 
John Dalton (1766-1844) was born in Cumberland, went to Kendal to teach school at the age of fifteen, and remained in the Lake District of England till 1793. In this region, where the annual rainfall exceeds forty inches, and in some localities is almost tropical, the young student's attention was early drawn to meteorology. His apparatus consisted of rude home-made rain-gauges, thermometers, and barometers. His interest in the heat, moisture, and constituents of the atmosphere continued throughout life, and Dalton made in all some 200,000 meteorological observations. We gain a clue to his motive in these studies from a letter written in his twentysecond year, in which he speaks of the advantages that might accrue to the husbandman, the mariner, and to mankind in general if we were able to predict the state of the weather with tolerable precision.

In 1793 Dalton took up his permanent residence in Manchester, and in that year appeared his first book, Meteorological Observations and Essays. Here he deals, among other things, with rainfall, the formation of clouds, evaporation, and the distribution and character of atmospheric moisture. It seemed to him that aqueous vapor always exists as a distinct fluid maintaining its identity among the other fluids of the atmosphere. He thought of atmospheric moisture as consisting of minute drops of water, or globules among the globules of oxygen and nitrogen. He was a disciple of Newton's (to whom, indeed, Dalton had some personal likeness), who looked upon matter as consisting of "solid, massy, hard, impenetrable, movable particles, of such sizes and figures, and with such other properties, and in such proportion, as 
most conduced to the end for which God formed them." Dalton was so much under the influence of the idea that the physical universe is made up of these indivisible particles, or atoms, that his biographer describes him as thinking corpuscularly. It is probable that his imagination was of the visualizing type and that he could picture to himself the arrangement of atoms in elementary and compound substances.

Now Dalton's master had taught that the atoms of matter in a gas (elastic fluid) repel one another by a force increasing in proportion as their distance diminishes. How did this teaching apply to the atmosphere, which Priestley and others had proved to consist of three or more gases? Why does this mixture appear simple and homogeneous? Why does not the air form strata with the oxygen below and the nitrogen above? Cavendish had shown, and Dalton himself later proved, that common air, wherever examined, contains oxygen and nitrogen in fairly constant proportions.

French chemists had sought to apply the principle of chemical affinity in'explaining the apparent homogeneity of the atmosphere. They supposed that oxygen and nitrogen entered into chemical union, the one element dissolving the other. The resultant compound in turn dissolved water; hence the phenomena of evaporation. Dalton tried in vain to reconcile this supposition with his belief in the atomic nature of matter. He drew diagrams combining an atom of oxygen with an atom of nitrogen and an atom of aqueous vapor. The whole atmosphere could not consist of such groups of three because the watery particles were but a small portion of the total atmosphere. 
He made a diagram in which one atom of oxygen was combined with one atom of nitrogen, but in this case the oxygen was insufficient to satisfy all the nitrogen of the atmosphere. If the air was made up partly of pure nitrogen, partly of a compound of nitrogen and oxygen, and partly of a compound of nitrogen, oxygen, and aqueous vapor, then the triple compound, as heaviest, would collect toward the surface of the earth, and the double compound and the simple substance would form two strata above. If to the compounds heat were added in the hope of producing an unstratified mixture, the atmosphere would acquire the specific gravity of nitrogen gas. "In short," says Dalton, "I was obliged to abandon the hypothesis of the chemical constitution of the atmosphere altogether as irreconcilable to the phenomena."

$\mathrm{He}$ had to return to the conception of the individual particles of oxygen, nitrogen, and water, each a center of repulsion. Still he could not explain why the oxygen did not gravitate to the lowest place, the nitrogen form a stratum above, and the aqueous vapor swim upon the top. In 1801, however, Dalton hit upon the idea that gases act as vacua for one another, that it is only like particles which repel each other, atoms of oxygen repelling atoms of oxygen and atoms of nitrogen repelling atoms of nitrogen when these gases are intermingled in the atmosphere just as they would if existing in an unmixed state. "According to this, we were to suppose that atoms of one kind did not repel the atoms of another kind, but only those of their own kind." A mixed atmosphere is as free from stratifications, as though it were really homogeneous. 
In his analyses of air Dalton made use of the old nitric oxide method. In 1802 this led to an interesting discovery. If in a tube .3 of an inch wide he mixed 100 parts of common air with 36 parts of nitric oxide, the oxygen of the air combined with the nitric oxide, and a residue of 79 parts of atmospheric nitrogen remained. And if he mixed 100 parts of common air with 72 of nitric oxide, but in a wide vessel over water (in which conditions the combination is more quickly effected), the oxygen of the air again combined with the nitric oxide and a residue of 79 parts of nitrogen again resulted. But in the last experiment, if less than 72 parts of nitric oxide be employed, there will be a residue of oxygen as well as nitrogen; and if more than 72 , there will be a residue of nitric oxide in addition to the nitrogen. In the words of Dalton, "oxygen may combine with a certain portion of nitrous gas [as he called nitric oxide], or with twice that portion, but with no intermediate portion."

Naturally these experimental facts were to be explained in terms of the ultimate particles of which the various gases are composed. In the following year Dalton gave graphic representation to his idea of the atomic constitution of chemical elements and compounds.
O Hydrogen
(1) Nitrogen
$\odot$ Oxygen
- Carbon
๑๑ Nitric oxide
$\odot \odot$ Carbonic acid
$\odot \triangleright \odot$ Nitrous oxide

Much against Dalton's will his method of indicating chemical elements and their combinations had to 
yield to a method introduced by the great Swedish chemist Berzelius. In 1837 Dalton wrote: "Berzelius's symbols are horrifying: a young student in chemistry might as soon learn Hebrew as make himself acquainted with them. They appear like a chaos of atoms ... and to equally perplex the adepts of science, to discourage the learner, as well as to cloud the beauty and simplicity of the Atomic Theory."

Meantime Dalton's mind had been turning to the consideration of the relative sizes and weights of the various elements entering into combination with one another. He argued that if there be not exactly the same number of atoms of oxygen in a given volume of air as of nitrogen in the same volume, then the sizes of the particles of oxygen must be different from those of nitrogen. His interest in the absorption of gases by water, in the reciprocal diffusion of gases, as well as in the phenomena of chemical combination, stimulated Dalton to determine the relative size and weight of the atoms of the various elements. Dalton said nothing of the absolute weight of the atom. But on the assumption that when only one compound of two elements is known to exist, the molecule of the compound consists of one atom of each of these elements, he proceeded to investigate the relative weights of equal numbers of the two sorts of atoms. In 1803 he pursued this investigation with remarkable success, and taking hydrogen (the lightest gas known to him) as unity, he arrived at a statement of the relative atomic weights of oxygen, nitrogen, carbon, etc. Dalton thus introduced into the study of chemical combination a very definite idea of quantitative relationship. By him 


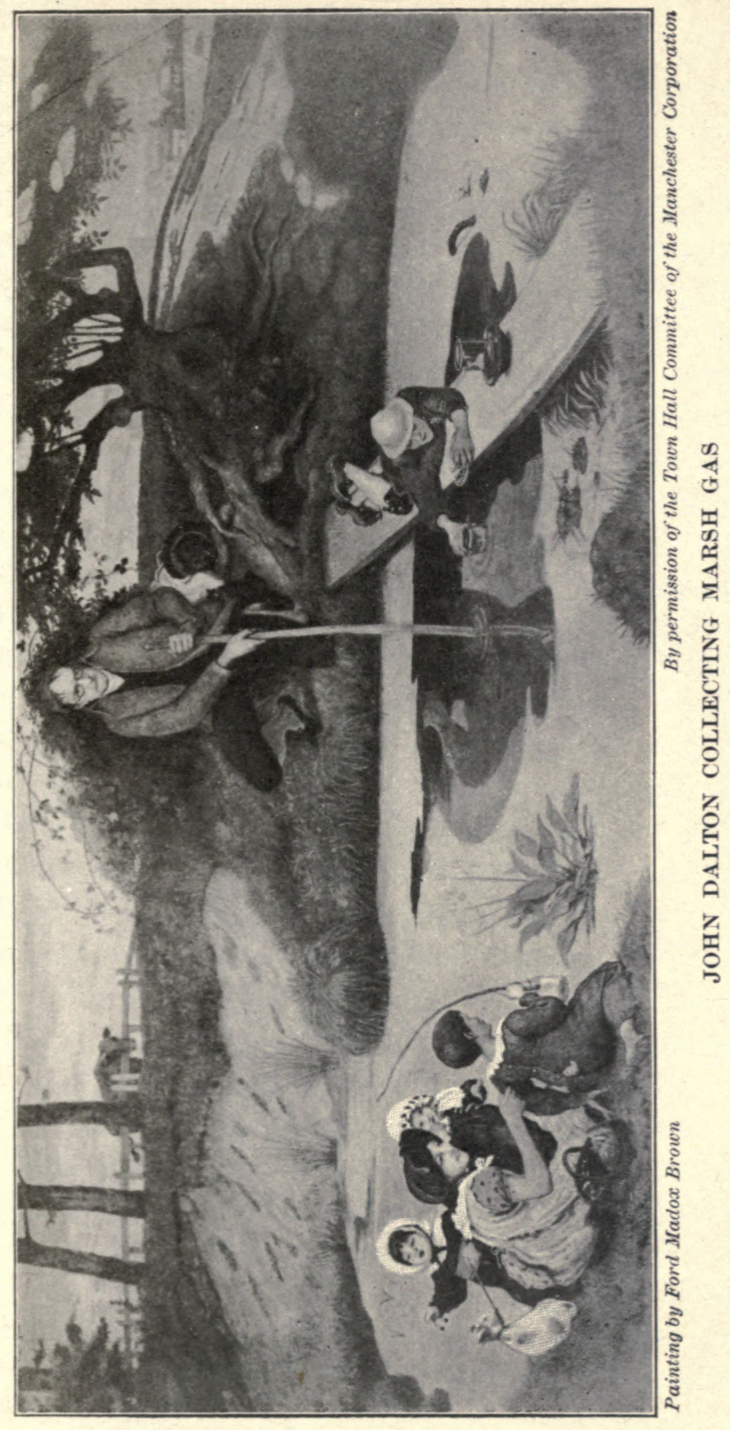



the atomic theory of the constitution of matter was made definite and applicable to all the phenomena known to chemistry.

During the following months he returned to the study of those cases in which the same elements combine to form more than one compound. We have seen that oxygen unites with nitric oxide to form two compounds, and that into the one compound twice as much nitric oxide (by weight) enters as into the other. A like relation was found in the weight of oxygen combining with carbon in the two compounds carbon monoxide and carbonic acid. In the summer of 1804 he investigated the composition of two compounds of hydrogen and carbon, marsh gas (methane) and olefiant gas (ethylene), and found that the first contained just twice as much hydrogen in relation to the carbon as the second compound contained. In a series of compounds of the same two elements one atom of one unites with one, two, three, or more atoms of the other; that is, a simple ratio exists between the weights in which the second element enters into combination with the first. This law of multiple proportions afforded confirmation of Dalton's atomic theory, or chemical theory of definite proportions.

"Without such a theory," says Sir Henry Roscoe, " modern chemistry would be a chaos; with it, order reigns supreme, and every apparently contradictory discovery only marks out more distinctly the value and importance of Dalton's work." In 1826 Sir Humphry Davy recognized Dalton's services to science in the following terms: "Finding that in certain compounds of gaseous bodies the same elements 
always combined in the same proportions, and that when there was more than one combination the quantity of the elements always had a constant relation, - such as 1 to 2 , or 1 to 3 , or 1 to $4,-$ he explained this fact on the Newtonian doctrine of indivisible atoms; and contended that, the relative weight of one atom to that of any other atom being known, its proportions or weight in all its combinations might be ascertained, thus making the statics of chemistry depend upon simple questions in subtraction or multiplication and enabling the student to deduce an immense number of facts from a few well-authenticated experimental results. Mr. Dalton's permanent reputation will rest upon his having discovered a simple principle universally applicable to the facts of chemistry, in fixing the proportions in which bodies combine, and thus laying the foundation for future labors respecting the sublime and transcendental parts of the science of corpuscular motion. His merits in this respect resemble those of Kepler in astronomy."

In 1808 Dalton's atomic theory received striking confirmation through the investigations of the French scientist Gay-Lussac, who showed that gases, under similar circumstances of temperature and pressure, always combine in simple proportions by volume when they act on one another, and that when the result of the union is a gas, its volume also is in a simple ratio to the volumes of its components. One of Dalton's friends summed up the result of GayLussac's research in this simple fashion: "His paper is on the combination of gases. He finds that all unite in equal bulks, or two bulks of one to one of another, 
or three bulks of one to one of another." When Dalton had investigated the relative weights with which elements combine, he had found no simple arithmetical relationship between atomic weight and atomic weight. When two or more compounds of the same elements are formed, Dalton found, however, as we have seen, that the proportion of the element added to form the second or third compound is a multiple by weight of the first quantity. Gay-Lussac now showed that gases, "in whatever proportions they may combine, always give rise to compounds whose elements by volume are multiples of each other."

In 1811 Avogadro, in an essay on the relative masses of atoms, succeeded in further confirming Dalton's theory and in explaining the atomic basis of Gay-Lussac's discovery of simple volume relations in the formation of chemical compounds. According to the Italian scientist the number of molecules in all gases is always the same for equal volumes, or always proportional to the volumes, it being taken for granted that the temperature and pressure are the same for each gas. Dalton had supposed that water is formed by the union of hydrogen and oxygen, atom for atom. Gay-Lussac found that two volumes of hydrogen combined with one volume of oxygen to produce two volumes of water vapor. According to Avogadro the water vapor contains twice as many atoms of hydrogen as of oxygen. One volume of hydrogen has the same number of molecules as one volume of oxygen. When the two volumes combine with one, the combination does not take place, as Dalton had supposed, atom for atom, but each half- 
molecule of oxygen combines with one molecule of hydrogen. The symbol for water is, therefore, not $\mathrm{HO}$ but $\mathrm{H}_{2} \mathrm{O}$.

Enough has been said to establish Dalton's claim to be styled a great lawgiver of chemical science. His influence in further advancing definitely formulated knowledge of physical phenomena can here be indicated only in part. In 1800 he wrote a paper On the Heat and Cold produced by the Mechanical Condensation and Rarefaction of Air. This contains, according to Dalton's biographer, the first quantitative statement of the heat evolved by compression and the heat evolved by dilatation. His contribution to the theory of heat has been stated thus : The volume of a gas under constant pressure expands when raised to the boiling temperature by the same fraction of itself, whatever be the nature of the gas. In 1798 Count Rumford had reported to the Royal Society his Enquiry concerning the Source of Heat excited by Friction, the data for which had been gathered at Munich. Interested as he was in the practical problem of providing heat for the homes of the city poor, Rumford had been struck by the amount of heat developed in the boring-out of cannon at the arsenal. He concluded that anything which could be created indefinitely by a process of friction could not be a substance, such as sulphur or hydrogen, but must be a mode of motion. In the same year the youthful Davy was following independently this line of investigation by rubbing two pieces of ice together, by clock-work, in a vacuum. The friction caused the ice to melt, although the experiment was undertaken in a temperature of $29^{\circ}$ Fahrenheit. 
For James Prescott Joule (1818-1889), who came of a family of brewers and was early engaged himself in the brewing industry, was reserved, however, the distinction of discovering the exact relation between heat and mechanical energy. After having studied chemistry under Dalton at Manchester, he became engrossed in physical experimentation. In 1843 he prepared a paper On the Calorific Effects of Magneto-Electricity and on the Mechanical Value of Heat. In this he dealt with the relations between heat and the ordinary forms of mechanical power, and demonstrated that the mechanical energy spent " in turning a magneto-electrical machine is converted into the heat evolved by the passage of the currents of induction through its coils ; and, on the other hand, that the motive power of the electro-magnetic engine is obtained at the expense of the heat due to the chemical reactions of the battery by which it is worked." In 1844 he proceeded to apply the principles maintained in his earlier study to changes of temperature as related to changes in the density of gases. He was conscious of the practical, as well as the theoretical, import of his investigation. Indeed, it was through the determination by this illustrious pupil of Dalton's of the amount of heat produced by the compression of gases that one of the greatest improvements of the steam engine was later effected. Joule felt that his investigation at the same time confirmed the dynamical theory of heat which originated with Bacon, and had at a subsequent period been so well supported by the experiments of Rumford, Davy, and others.

Already, in this paper of June, 1844, Joule had 
expressed the hope of ascertaining the mechanical equivalent of heat with the accuracy that its importance for physical science demanded. He returned to this question again and again. According to his final result the quantity of heat required to raise one pound of water in temperature by one degree Fahrenheit is equivalent to the mechanical energy required to raise 772.55 pounds through a distance of one foot. Heat was thus demonstrated to be a form of energy, the relation being constant between it and mechanical energy. Mechanical energy may be converted into heat; if heat disappears, some other form of energy, equivalent in amount to the heat lost, must replace it. The doctrine that a certain quantity of heat is always equivalent to a certain amount of mechanical energy is only a special case of the Law of the Conservation of Energy, first clearly enunciated by Joule and Helmholtz in 1847, and generally regarded as the most important scientific discovery of the nineteenth century.

Roscoe, referring to the two life-sized marble statues which face each other in the Manchester Town Hall, says with pardonable pride: "Thus honor is done to Manchester's two greatest sons - to Dalton, the founder of modern Chemistry and of the Atomic Theory, and the discoverer of the laws of chemical combining proportions ; to Joule, the founder of modern Physics and the discoverer of the Law of the Conservation of Energy." 


\section{THE REIGN OF LAW}

\section{REFERENCES}

Alembic Club Reprints, Foundations of the Atomic Theory. Joseph Priestley, Experiments and Observations on Different Kinds of Air.

Sir William Ramsay, The Gases of the Atmosphere and the History of their Discovery.

Sir Henry E. Roscoe, John Dalton.

Sir E. Thorpe, Essays in Historical Chemistry. 


\section{CHAPTER XIII}

THE SCIENTIST - SIR HUMPHRY DAVY

Humphry Davy (1778-1829) was born in Cornwall, a part of England known for its very mild climate and the combined beauty and majesty of its scenery. On either side of the peninsula the Atlantic in varying mood lies extended in summer sunshine, or from its shroud of mist thunders on the black cliffs and their time-sculptured sandstones. From the coast inland, stretch, between flowered lanes and hedges, rolling pasture-lands of rich green made all the more vivid by the deep reddish tint of the ploughed fields. In Penzance, then a town of about three thousand inhabitants, and in its picturesque vicinity, the early years of Davy's life were passed. Across the bay rose the great vision of the guarded mount (St. Michael's) of which Milton's verse speaks. Farther to the east lay Lizard Head, the southernmost promontory of England, and a few miles to the north St. Ives with its sweep of sandy beach; while not far to the west of Penzance Land's End stood sentry "'Twixt two unbounded seas." The youthful Davy was keenly alive to the charms of his early environment, and his genius was susceptible to the belief in supernatural agencies native to the imaginative Celtic people among whom he was reared. As a precocious child of five he improvised rhymes, and as a youth set forth in excellent verse the glories of Mount's Bay:- 
" There did I first rejoice that I was born Amidst the majesty of azure seas."

Davy received what is usually called a liberal education, putting in nine years in the Penzance and one year in the Truro Grammar School. His best exercises were translations from the classics into English verse. He was rather idle, fond of fishing (an enthusiasm he retained throughout life) and shooting, and less appreciated and beloved by his masters than by his school-fellows, who recognized his wonderful abilities, sought his aid in their Latin compositions (as well as in the writing of letters and valentines), and listened eagerly to his imaginative tales of wonder and horror. Years later he wrote to his mother: "After all, the way in which we are taught Latin and Greek does not much influence the important structure of our minds. I consider it fortunate that I was left much to myself when a child, and put upon no particular plan of study, and that I enjoyed much idleness at Mr. Coryton's school. I perhaps owe to these circumstances the little talents that I have and their peculiar application."

When Davy was about sixteen years old, his father died, leaving the widow and her five children, of whom Humphry was the eldest, with very scanty provision. The mind of the youth seemed to undergo an immediate change. He expressed his resolution (which he nobly carried out) to play his part as son and brother. Within a few weeks he became apprenticed to an apothecary and surgeon, and, having thus found his vocation, drew up his own particular plan of self-education, to which he rigidly adhered. His brother, Dr. John Davy, bears witness 
that the following is transcribed from a notebook of Humphry's, bearing the date of the same year as his apprenticeship (1795):-

$\left.\begin{array}{l}\text { 1. Theology or Religion } \\ \text { Ethics or Moral Virtues }\end{array}\right\} \quad \begin{gathered}\text { Taught by Nature. } \\ \text { by Revelation. }\end{gathered}$

2. Geography.

3. My Profession -

1. Botany. 2. Pharmacy. 3. Nosology. 4. Anatomy.

5. Surgery. 6. Chemistry.

4. Logic.

5. Language, etc.

A series of essays which Davy wrote in pursuing his scheme of self-culture proves how rapidly his mind drew away from the superstitions which characterized the masses of the people among whom he lived. He had as a boy been haunted by the fear of monsters and witches in which the credulous of all classes then believed. His notebook shows that he was now subjecting to examination the religious and political opinions of his time. He composed essays on the immortality and immateriality of the soul, on governments, on the credulity of mortals, on the dependence of the thinking powers on the organization of the body, on the ultimate end of being, on happiness, and on moral obligation. He studied the writings of Locke, Hartley, Berkeley, Hume, Helvetius, Condorcet, and Reid, and knew something of German philosophy. It was not till he was nineteen that Davy entered on the experimental study of chemistry.

Guided by the Elements of Lavoisier, encouraged by the friendship of Gregory Watt (a son of James Watt) and by another gentleman of university edu- 
cation, stimulated by contact with the Cornish mining industry, Davy pursued this new study with zeal, and within a few months had written two essays full of daring generalizations on the physical sciences. These were published early in 1792. Partly on the basis of the ingenious experiment mentioned in the preceding chapter, he came to the conclusion that "Heat, or that power which prevents the actual contact of the corpuscles of bodies, and which is the cause of our peculiar sensations of heat and cold, may be defined as a peculiar motion, probably a vibration, of the corpuscles of bodies, tending to separate them." Other passages might be quoted from these essays to show how the gifted youth of nineteen anticipated the science of subsequent decades, but in the main these early efforts were characterized by the faults of overwrought speculation and incomplete verification. He soon regretted the premature publication of his studies. "When I consider," he wrote, "the variety of theories that may be formed on the slender foundation of one or two facts, I am convinced that it is the business of the true philosopher to avoid them altogether. It is more laborious to accumulate facts than to reason concerning them; but one good experiment is of more value than the ingenuity of a brain like Newton's."

In the mean time Davy had been chosen superintendent of the Pneumatic Institution at Bristol by Dr. Beddoes, its founder. It was supported by the contributions of Thomas Wedgwood and other distinguished persons, and aimed at discovering by means of experiment the physiological effect of inhaling different gases, or "factitious airs," as they 
were called. The founding of such an establishment has been termed a scientific aberration, but the use now made in medical practice of oxygen, nitrous oxide, chloroform, and other inhalations bears witness to the sanity of the sort of research there set on foot. Even before going to Bristol, Davy had inhaled small quantities of nitrous oxide mixed with air, in spite of the fact that this gas had been held by a medical man to be the "principle of contagion." He now carried on a series of tests, and finally undertook an extended experiment with the assistance of a doctor. In an air-tight or box-chamber he inhaled great quantities of the supposedly dangerous gas. After he had been in the box an hour and a quarter, he respired twenty quarts of pure nitrous oxide. He described the experience in the following words :-

"A thrilling, extending from the chest to the extremities, was almost immediately produced. I felt a sense of tangible extension highly pleasurable in every limb; my visible impressions were dazzling, and apparently magnified; I heard every sound in the room, and was perfectly aware of my situation. By degrees, as the pleasurable sensations increased, I lost all connection with external things; trains of vivid visible images rapidly passed through my mind, and were connected with words in such a manner, as to produce perceptions perfectly novel. I existed in a world of newly connected and newly modified ideas: I theorized, I imagined that I made discoveries. When I was awakened from this semi-delirious trance by Dr. Kinglake, who took the bag from my mouth, indignation and pride were the first feelings 
produced by the sight of the persons about me. My emotions were enthusiastic and sublime, and for a minute I walked round the room perfectly regardless of what was said to me. As I recovered my former state of mind, I felt an inclination to commanicate the discoveries I had made during the experiment. I endeavored to recall the ideas: they were feeble and indistinct; one collection of terms, however, presented itself ; and with the most intense belief and prophetic manner, I exclaimed to Dr. Kinglake, 'Nothing exists but thoughts! The universe is composed of impressions, ideas, pleasures and pains!" "

Davy aroused the admiration and interest of every one who met him. A literary man to whom he was introduced shortly after his arrival in Bristol spoke of the intellectual character of the young man's face. His eye was piercing, and when he was not engaged in conversation, its expression indicated abstraction, as though his mind were pursuing some severe train of thought scarcely to be interrupted by external objects; " and," this writer adds, "his ingenuousness impressed me as much as his mental superiority." Mrs. Beddoes, a gay, witty, and elegant lady, and an ardent admirer of the youthful scientist, was a sister of Maria Edgeworth. The novelist's tolerance of Davy's enthusiasm soon passed into a clear recognition of his commanding genius. Coleridge, Southey, and other congenial friends, whom the chemist met under Dr. Beddoes' roof, shared in the general admiration of his mental and social qualities. Southey spoke of him as a miraculous young man, at whose talents he could only wonder. Coleridge, when asked 
how Davy compared with the cleverest men he had met on a visit to London, replied expressively: "Why, Davy can eat them all! There is an energy, an elasticity in his mind, which enables him to seize on and analyze all questions, pushing them to their legitimate consequences. Every subject in Davy's mind has the principle of vitality. Living thoughts spring up like turf under his feet." He thought that if Davy had not been the first chemist he would have been the first poet of the age. Their correspondence attests the intimate interchange of ideas and sentiments between these two men of genius, so different, yet with so much in common.

In 1801 Davy was appointed assistant lecturer in chemistry at the Royal Institution (Albemarle Street, London), which had been founded from philanthropic motives by Count Rumford in 1799. Its aim was to promote the application of science to the common purposes of life. Its founder desired while benefiting the poor to enlist the sympathies of the fashionable world. Davy, with a zeal for the cause of humanity and a clear recognition of the value of a knowledge of chemistry in technical industries and other daily occupations, lent himself readily to the founder's plans. His success as a public expositor of science soon won him promotion to the professorship of chemistry in the new institution, and through his influence an interest in scientific investigation became the vogue of London society. His popularity as a lecturer was so great that his best friends feared that the head of the brilliant provincial youth of twenty-two might be turned by the adulation of which he soon became the object. "I have read," 


\section{THE SCIENTIST}

writes his brother, "copies of verses addressed to him then, . . . anonymous effusions, some of them displaying much poetical taste as well as fervor of writing, and all showing the influence which his appearance and manner had on the more susceptible of his audience."

His study of the tanning industry (1801-1802) and his lectures on agricultural chemistry (18031813) are indicative of the early purpose of the Royal Institution and of Davy's lifelong inclination. The focus of his scientific interest, however, rested on the furtherance of the application of the electrical studies of Galvani and Volta in chemical analysis. In a letter to the chairman of managers of the Royal Institution Volta had in $\mathbf{1 8 0 0}$ described his voltaic pile made up of a succession of zinc and copper plates in pairs separated by a moist conductor, and before the end of the same year Nicholson and Carlisle had employed an electric current, produced by this newly devised apparatus, in the decomposition of water into its elements.

In the spring of the following year the Philosophical Magazine states: "We have also to notice a course of lectures, just commenced at the institution, on a new branch of philosophy - we mean Galvanic Phenomena. On this interesting branch Mr. Davy (late of Bristol) gave the first lecture on the 25th of April. He began with the history of Galvanism, detailed the successive discoveries, and described the different methods of accumulating influence. . . . He showed the effects of galvanism on the legs of frogs, and exhibited some interesting experiments on the galvanic effects on the solutions of metals in acids." 
In a paper communicated to the Royal Society in 1806, On Some Chemical Agencies of Electricity, Davy put on record the result of years of experiment. For example, as stated by his biographer, he had connected a cup of gypsum with one of agate by means of asbestos, and filling each with purified water, had inserted the negative wire of the battery in the agate cup, and the positive wire in that of the sulphate of lime. In about four hours he had found a strong solution of lime in the agate cup, and sulphuric acid in the cup of gypsum. On his reversing the arrangement, and carrying on the process for a similar length of time, the sulphuric acid appeared in the agate cup, and the solution of lime on the opposite side. It was thus that he studied the transfer of certain of the constituent parts of bodies by the action of electricity. "It is very natural to suppose," says Davy, "that the repellent and attractive energies are communicated from one particle to another particle of the same kind, so as to establish a conducting chain in the fluid. There may be a succession of decompositions and recompositions before the electrolysis is complete."

The publication of this paper in 1806 attracted much attention abroad, and gained for him - in spite of the fact that England and France were then at war - a medal awarded, under an arrangement instituted by Napoleon a few years previously, for the best experimental work on the subject of electricity. "Some people," said Davy, "say I ought not to accept this prize; and there have been foolish paragraphs in the papers to that effect; but if the two countries or governments are at war, the men of 
science are not. That would, indeed, be a civil war of the worst description: we should rather, through the instrumentality of men of science, soften the asperities of national hostility."

In the following year Davy reported other chemical changes produced by electricity; he had succeeded in decomposing the fixed alkalis and discovering the elements potassium and sodium. To analyze a small piece of pure potash slightly moist from the atmosphere, he had placed it on an insulated platinum disk connected with the negative side of a voltaic battery. A platinum wire connected with the positive side was brought in contact with the upper surface of the alkali. "The potash began to fuse at both its points of electrization." At the lower (negative) surface small globules having a high metallic luster like quicksilver appeared, some of which burned with explosion and flame while others remained and became tarnished. When Davy saw these globules of a hitherto unknown metal, he danced about the laboratory in ecstasy and for some time was too much excited to continue his experiments.

After recovering from a very severe illness, owing . in the judgment of some to overapplication to experimental science, and in his own judgment to a visit to Newgate Prison with the purpose of improving its sanitary condition, Davy made an investigation of the alkaline earths. He failed in his endeavor to obtain from these sources pure metals, but he gave names to barium, strontium, calcium, and magnesium, conjecturing that the alkaline earths were, like potash and soda, metallic oxides. In addition Davy anticipated the isolation of silicon, aluminium, and zirco- 
nium. No doubt what gave special zest to his study of the alkalis was the hope of overthrowing the doctrine of French chemists that oxygen was the essential element of every acid. Lavoisier had given it, indeed, the name oxygen (acid-producer) on that supposition. Davy showed, however, that this element is a constituent of many alkalis.

In 1810 he advanced his controversy by explaining the nature of chlorine. Discovered long before by the indefatigable Scheele, it bore at the beginning of the nineteenth century the name oxymuriatic acid. Davy proved that it contained neither oxygen nor muriatic (hydrochloric) acid (though, as we know, it forms, with hydrogen, muriatic acid). He gave the name chlorine because of the color of the gas ( $\chi \lambda \omega \rho$ ós, pale green). Davy studied later the compounds of fluorine, and though unable to isolate the element, conjectured its likeness to chlorine.

He lectured before the Dublin Society in 1810 , and again in the following year; on the occasion of his second visit receiving the degree of LL.D. from Trinity College. He was knighted in the spring of 1812, and was married to a handsome, intellectual, and wealthy lady. He was appointed Honorary Professor of Chemistry at the Royal Institution. His new independence gave him full liberty to pursue his scientific interests. Toward the close of 1812 he writes to Lady Davy:-

"Yesterday I began some new experiments to which a very interesting discovery and a slight accident put an end. I made use of a compound more powerful than gunpowder destined perhaps at some time to change the nature of war and influence the 
state of society. An explosion took place which has done me no other harm than that of preventing me from working this day and the effects of which will be gone to-morrow and which I should not mention at all, except that you may hear some foolish exaggerated account of it, for it really is not worth mentioning. ..." The compound on the investigation of which he was then engaged is now known as the trichloride of nitrogen.

In the autumn of 1813 Sir Humphry and Lady Davy, accompanied by Michael Faraday, who on Davy's recommendation had in the spring of the same year received a post at the Royal Institution, set out, in spite of the continuance of the war, on a Continental tour. At Paris Sir Humphry was welcomed by the French scientists with every mark of distinction. A substance which had been found in the ashes of seaweed two years previously, by a soapboiler and manufacturer of saltpeter, was submitted to Davy for chemical examination. Until Davy's arrival in Paris little had been done to determine its real character. On December 6 Gay-Lussac presented a brief report on the new substance, which he named iode and considered analogous to chlorine. Davy, working with almost incredible rapidity in the presence of his rivals, was able a week later to sketch the chief characters of this new element, now known by the name he chose for it -iodine.

We have passed over his investigation of boracic acid, ammonium nitrate, and other compounds; we can merely mention in passing his later studies of the diamond and other forms of carbon, of the chemical constituents of the pigments used by the 
ancients, his investigation of the torpedo fish, and his anticipation of the arc light.

It seems fitting that Sir Humphry Davy should be popularly remembered for his invention of the miner's safety-lamp. At the beginning of the nineteenth century the development of the iron industry, the increasing use of the steam engine and of machinery in general led to great activity and enterprise in the working of the coal mines. Colliery explosions of fire-damp (marsh gas) became alarmingly frequent, especially in the north of England. The mine-owners in some cases sought to suppress the news of fatalities. A society, however, was formed to protect the miners from injury through gas explosions, and Davy was asked for advice. On his return from the Continent in $\mathbf{1 8 1 5}$ he applied himself energetically to the matter. He visited the mines and analyzed the gas. He found that fire-damp explodes only at high temperature, and that the flame of this explosive mixture will not pass through small apertures. A miner's lamp was therefore constructed with wire gauze about the flame to admit air for combustion. The fire-damp entering the gauze burned quietly inside, but could not carry a high enough temperature through the gauze to explode the large quantity outside. To one of the members of the philanthropic society which had appealed to him Davy wrote: "I have never received so much pleasure from the result of any of my chemical labours; for I trust the cause of humanity will gain something by it."

Davy was elected President of the Royal Society in 1820 , and retained that dignity till he felt com- 
pelled by ill health to relinquish it in 1827 . "It was his wish," says his brother, "to have seen the Royal Society an efficient establishment for all the great practical purposes of science, similar to the college contemplated by Lord Bacon, and sketched in his New Atlantis; having subordinate to it the Royal Observatory at Greenwich for astronomy; the British Museum, for natural history, in its most extensive acceptation."

Sir Humphry Davy, after a life crowded with splendid achievements, died at Geneva in 1829 with many of his noblest dreams unfulfilled. Fortunately in Michael Faraday, who is sometimes referred to as the greatest of his discoveries, he had a successor who was fully adequate to the task of furthering the various investigations that his genius had set on foot, and who, to the majority of men of mature mind, is no less personally interesting than the Cornish scientist, poet, and philosopher.

\section{REFERENCES}

John Davy, Works of Sir Humphry Davy.

John Davy, Fragmentary Remains, literary and scientific, of Sir Humphry Davy, Bart.

Bence Jones, Life and Letters of Faraday.

John Tyndall, Faraday as a Discoverer.

E. v. Meyer, History of Chemistry.

S. P. Thompson, Michael Faraday; his Life and Work.

Sir Edward Thorpe, Humphry Davy, Poet and Philosopher. 


\section{CHAPTER XIV}

SCIENTIFIC PREDICTION - THE DISCOVERY OF NEPTUNE

UNDER this heading we have to consider a single illustration - the prediction, and the discovery, in 1846, of the planet Neptune. This event roused great enthusiasm among scientists as well as in the popular mind, afforded proof of the reliability of the Newtonian hypothesis, and demonstrated the precision to which the calculation of celestial motions had attained. Scientific law appeared not merely as a formulation and explanation of observed phenomena but as a means for the discovery of new truths. "Would it not be admirable," wrote Valz to Arago in 1835, "to arrive thus at a knowledge of the existence of a body which cannot be perceived?"

The prediction and discovery of Neptune, to which many minds contributed, and which has been described with a show of justice as a movement of the times, arose from the previous discovery of the planet Uranus by Sir William Herschel in 1781. After that event Bode suggested that it was possible other astronomers had observed Uranus before, without recognizing it as a planet. By a study of the star catalogues this conjecture was soon verified. It was found that Flamsteed had made, in 1690, the first observation of the heavenly body now called Uranus. Ultimately it was shown that there were at least seventeen similar observations prior to 1781 . 
It might naturally be supposed that these socalled ancient observations would lead to a ready determination of the planet's orbit, mass, mean distance, longitude with reference to the sun, etc. The contrary, however, seemed to be the case. When Alexis Bouvard, the associate of Laplace, prepared in 1821 tables of Uranus, Jupiter, and Saturn on the principles of the Mécanique Céleste, he was unable to fix an orbit for Uranus which would harmonize with the data of ancient and modern observations, that is, those antecedent and subsequent to Herschel's discovery in 1781. If he computed an orbit from the two sets of data combined, the requirements of the earlier observations were fairly well met, but the later observations were not represented with sufficient precision. If on the other hand only the modern data were taken into account, tables could be constructed meeting all the observations subsequent to 1781 , but failing to satisfy those prior to that date. A consistent result could be obtained only by sacrificing the modern or the ancient observations. "I have thought it preferable," says Bouvard, " to abide by the second [alternative], as being that which combines the greater number of probabilities in favor of the truth, and I leave it to the future to make known whether the difficulty of reconciling the two systems result from the inaccuracy of ancient observations, or whether it depend upon some extraneous and unknown influence, which has acted on the planet." It was not till three years after the death of Alexis Bouvard that the extraneous influence, of which he thus gave in 1821 some indicas tion, became fully known. 
Almost immediately, however, after the publication of the tables, fresh discrepancies arose between computation and observation. At the first meeting of the British Association in 1832 Professor Airy in a paper on the Progress of Astronomy showed that observational data in reference to the planet Uranus diverged widely from the tables of 1821 . In 1833 through his influence the "reduction of all the planetary observations made at Greenwich from 1750" was undertaken. Airy became Astronomer Royal in 1835, and continued to take special interest in Uranus, laying particular emphasis on the fact that the radius vector assigned in the tables to this planet was much too small.

In 1834 the Reverend T. J. Hussey, an amateur astronomer, had written to Airy in reference to the irregularities in the orbit of Uranus: "The apparently inexplicable discrepancies between the ancient and modern observations suggested to me the possibility of some disturbing body beyond Uranus, not taken into account because unknown. . . Subsequently, in conversation with Bouvard, I inquired if the above might not be the case." Bouvard answered that the idea had occurred to him; indeed, he had had some correspondence in reference to it in $\mathbf{1 8 2 9}$ with Hansen, an authority on planetary perturbations.

In the following year Nicolai (as well as Valz) was interested in the problem of an ultra-Uranian planet in connection with the orbit of Halley's comet (itself the subject of a striking scientific prediction fulfilled in 1758), now reappearing, and under the disturbing influence of Jupiter. In fact, the proba- 
bility of the approaching discovery of a new planet soon found expression in popular treatises on astronomy. Mrs. Somerville in her book on The Connection of the Physical Sciences (1836) said that the discrepancies in the records of Uranus might reveal the existence and even " the mass and orbit of a body placed for ever beyond the sphere of vision." Similarly Mädler in his Popular Astronomy (1841) took the view that Uranus might have been predicted by study of the perturbations it produced in the orbit of Saturn. Applying this conclusion to a body beyond Uranus we, he continued, "may, indeed, express the hope that analysis will one day or other solemnize this, her highest, triumph, making discoveries with the mind's eye in regions where, in our actual state, we are unable to penetrate."

One should not pass over in this account the labors of Eugène Bouvard, the nephew of Alexis, who continued to note anomalies in the orbit of Uranus and to construct new planetary tables till the very eve of the discovery of Neptune. In 1837 he wrote to Airy that the differences between the observations of Uranus and the calculation were large and were becoming continually larger: "Is that owing to a perturbation brought about in this planet by some body situated beyond it? I don't know, but that's my uncle's opinion."

In 1840 the distinguished astronomer Bessel declared that attempts to explain the discrepancies " must be based on the endeavor to discover an orbit and a mass for some unknown planet, of such a nature, that the resulting perturbations of Uranus may reconcile the present want of harmony in the 
observations." Two years later he undertook researches in reference to the new planet of whose existence he felt certain. His labors, however, were interrupted by the death of his assistant Flemming, and by his own illness, which proved fatal in 1846 , a few months before the actual discovery of Neptune. It is evident that the quest of the new planet had become general. The error of Uranus still amounted to less than two minutes. This deviation from the computed place is not appreciable by the naked eye, yet it was felt, by the scientific world, to challenge the validity of the Newtonian theory, or to foreshadow the addition of still another planet to our solar system.

In July, 1841, John Couch Adams, a young undergraduate of St. John's College, Cambridge, whose interest had been aroused by reading Airy's paper on the Progress of Astronomy, made note of his resolution to attempt, after completing his college course, the solution of the problem then forming in so many minds. After achieving the B.A. as senior wrangler at the beginning of 1843, Adams undertook to "find the most probable orbit and mass of the disturbing body which has acted on Uranus." The ordinary problem in planetary perturbations calls for the determination of the effect on a known orbit exerted by a body of known mass and motion. This was an inverse problem; the perturbation being given, it was required to find the position, mass, and orbit of the disturbing planet. The data were further equivocal in that the elements of the given planet Uranus were themselves in doubt; the unreliability of its planetary tables, in fact, being the 
occasion of the investigation now undertaken. That thirteen unknown quantities were involved indicates sufficiently the difficulty of the problem.

Adams started with the assumptions, not improbable, that the orbit of the unknown planet was a circle, and that its distance from the sun was twice that of Uranus. This latter assumption was in accord with the so-called "Bode's Law," which taught that a simple numerical relationship exists between the planetary distances $(4,7,10,16,28,52,100,196)$, and that the planets as they lie more remote from the sun tend to be more nearly double the distance of the next preceding. Adams was encouraged, by his first attempt, to undertake a more precise determination.

On his behalf Professor Challis of Cambridge applied to Astronomer Royal Airy, who furnished the Reductions of the Planetary Observations made at Greenwich from 1750 till 1830. In his second endeavor Adams assumed that the unknown planet had an elliptical orbit. He approached the solution gradually, ever taking into account more terms of the perturbations. In September, 1845, he gave the results to Challis, who wrote to Airy on the $22 \mathrm{~d}$ of that month that Adams sought an opportunity to submit the solution personally to the Astronomer Royal. On the 21 st of October, 1845 , the young mathematician, twice disappointed in his attempt to meet Airy, left at the Royal Observatory a paper containing the elements of the new planet. The position assigned to it was within about one degree of its actual place.

On November 5 Airy wrote to Adams and, among other things, inquired whether the solution obtained 
would account for the errors of the radius vector as well as for those of heliocentric longitude. For Airy this was a crucial question; but to Adams it seemed unessential, and he failed to reply.

By this time a formidable rival had entered the field. Leverrier at the request of Arago had undertaken to investigate the irregularities in the tables of Uranus. In September of the same year Eugène Bouvard had presented new tables of that planet. Leverrier acted very promptly and systematically. His first paper on the problem undertaken appeared in the Comptes Rendus of the Académie des Sciences November 10, 1845. He had submitted to rigorous examination the data in reference to the disturbing influence of Jupiter and of Saturn on the orbit of Uranus. In his second paper, June 1,1846 , Leverrier reviewed the records of the ancient and modern observations of Uranus (279 in all), subjected Bouvard's tables to severe criticism, and decided that there existed in the orbit of Uranus anomalies that could not be accounted due to errors of observation. There must exist some extraneous influence, hitherto unknown to astronomers. Some scientists had thought that the law of gravitation did not hold at the confines of the solar system (others that the attractive force of other systems might prove a factor), but Leverrier rejected this conception. Other theories being likewise discarded he asked: "Is it possible that the irregularities of Uranus are due to the action of a disturbing planet, situated in the ecliptic at a mean distance double that of Uranus? And if so, at what point is this planet situated? What is its mass? What are the 
elements of the orbit which it describes?" The conclusion reached by the calculations recorded in this second paper was that all the so-called anomalies in the observations of Uranus could be explained as the perturbation caused by a planet with a heliocentric longitude of $252^{\circ}$ on January 1,1800 . This would correspond to $325^{\circ}$ January 1, 1847.

Airy received Leverrier's second paper on June 23, and was struck by the fact that the French mathematician assigned the same place to the new planet as had Adams in the preceding October. He wrote to Leverrier in reference to the errors of the radius vector and received a satisfactory and sufficiently compliant reply. At one time the Astronomer Royal had felt very skeptical about the possibility of the discovery which his own labors had contributed to advance. He had always, to quote his own rather nebulous statement, considered the correctness of a distant mathematical result to be the subject of moral rather than of mathematical evidence. Now that corroboration of Adams's results had arrived, he felt it urgent to make a telescopic examination of that part of the heavens indicated by the theoretical findings of Adams and Leverrier. He accordingly wrote to Professor Challis, July 9, requesting him to employ for the purpose the great Northumberland equatorial of the Cambridge Observatory.

Professor Challis had felt, to use his own language, that it was so novel a thing to undertake observations in reliance upon merely theoretical deductions, that, while much labor was certain, success appeared very doubtful. Nevertheless, having received fresh instructions from Adams relative to the theoretical 
place of the new planet, he began observations July 29. On August 4 in fixing certain reference points he noted, but mistook for a star, the new planet. On August 12, having directed the telescope in accordance with Adams's instructions he again noted the same heavenly body, as a star. Before Challis had compared the results of the observation of August 12 with the results of an observation of the same region made on July 30 , and arrived at the inference that the body in question, being absent in the latter observation, was not a star but a planet, the prize of discovery had fallen into the hands of another observer.

On August 31 had appeared Leverrier's third paper, in which were stated the new planet's orbit, mass, distance from the sun, eccentricity, and longitude. The true heliocentric longitude was given as $326^{\circ} 32^{\prime}$ for January 1, 1847. This determination placed the planet about $5^{\circ}$ to the east of star $\delta$ of Capricorn. Leverrier said it might be recognized by its disk, which, moreover, would subtend a certain angle.

The systematic and conclusive character of Leverrier's research, submitted to one of the greatest academies of science, carried conviction to the minds of astronomers. The learned world felt itself on the eve of a great discovery. Sir John Herschel, in an address before the British Association on September 10 , said that the year past had given prospect of a new planet. "We see it as Columbus saw America from the shores of Spain. Its movements have been felt trembling along the far-reaching line of our analysis with a certainty hardly inferior to ocular demonstration." 
On September 18 Leverrier sent a letter to Dr. Galle, of the Berlin Observatory, which was provided with a set of star maps, prepared at the instance of Bessel. Galle replied one week later. "The planet, of the position of which you gave the indication, really exists. The same day that I received your letter [September 23] I found a star of the eighth magnitude, which was not inscribed in the excellent map (prepared by Dr. Bremiker) belonging to the collection of star maps of the Royal Academy of Berlin. The observation of the following day showed decisively that it was the planet sought." It was only $57^{\prime}$ from the point predicted.

Arago said that the discovery made by Leverrier was one of the most brilliant manifestations of the precision of modern astronomic science. It would encourage the best geometers to seek with renewed ardor the eternal truths which, in Pliny's phrase, are latent in the majesty of theory.

Professor Challis received Leverrier's third paper on September 29, and in the evening turned his magnificent refractor to the part of the heavens that Leverrier had so definitely and so confidently indicated. Among the three hundred stars observed Challis was struck by the appearance of one which presented a disk and shone with the brightness of a star of the eighth magnitude. This proved to be the planet. On October 1 Challis heard that the German observer had anticipated him.

Arago, while recognizing the excellent work done by Adams in his calculations, thought that the fact that the young mathematician had failed to publish his results should deprive him of any share whatever in the 
glory of the discovery of the new planet, and that history would confirm this definite judgment. Arago named the new planet after the French discoverer, but soon acquiesced in the name Neptune, which has since prevailed.

Airy, in whose possession Adams's results had remained for months unpublished and unheeded, wrote Leverrier: "You are to be recognized beyond doubt as the predictor of the planet's place." A vigorous official himself, Airy was deeply impressed by the calm decisiveness and definite directions of the French mathematician. "It is here, if I mistake not, that we see a character far superior to that of the able, or enterprising, or industrious mathematician; it is here that we see the philosopher." This explains, if anything could, his view that a distant mathematical result is the subject of ethical rather than of mathematical evidence.

Adams's friends felt that he had not received from either of the astronomers, to whom he confided his results, the kind of help or advice he should have received. Challis was kindly, but wanting in initiative. Although he had command of the great Northumberland telescope, he had no thought of commencing the search in 1845 , for, without mistrusting the evidence which the theory gave of the existence of the planet, it might be reasonable to suppose that its position was determined but roughly, and that a search for it must necessarily be long and laborious. In the view of Simon Newcomb, ${ }^{1}$ Adans's results, which were delivered at the Greenwich Observatory October 21, 1845 , were so near to the mark that a few hours'

1 See article "Neptune," Encyc. Brit. 
close search could not have failed to make the planet known.

Both Adams and Leverrier had assumed as a rough approximation at starting that the orbit of the new planet was circular and that, in accordance with Bode's Law, its distance was twice that of Uranus. S. C. Walker, of the Smithsonian Institution, Washington, was able to determine the elements of the orbit of Neptune accurately in 1847. In February of that year he had found (as had Petersen of Altona about the same time) that Lalande had in May, 1795, observed Neptune and mistaken it for a fixed star. When Lalande's records in Paris were studied, it was found that he had made two observations of Neptune on May 8 and 10. Their failure to agree caused the observer to reject one and mark the other as doubtful. Had he repeated the observation, he might have noted that the star moved, and was in reality a planet.

Neptune's orbit is more nearly circular than that of any of the major planets except Venus. Its distance is thirty times that of the earth from the sun instead of thirty-nine times, as Bode's Law would require. That generalization was a presupposition of the calculations leading to the discovery. It was then rejected like a discredited ladder. Man's conception of the universe is widened at the thought that the outmost known planet of our solar system is about 2,796,000,000 miles from the sun and requires about 165 years for one revolution.

Professor Peirce, of Harvard University, pointing to the difference between the calculations of Leverrier and the facts, put forward the view that 


\section{THE HISTORY OF SCIENCE}

the discovery made by Galle must be regarded as a happy accident. This view, however, has not been sustained.

\section{REFERENCES}

Sir Robert Ball, Neptune's Jubilee Year, Scientific American, Supplement, Oct. 10, 1896.

Sir Robert Ball, The Story of the Heavens, chap. xv.

B. A. Gould, Report on the History of the Discovery of Neptune, Smithsonian Contributions to Knowledge, 1850.

Robert Grant, History of Physical Astronomy.

Simon Newcomb, Popular Astronomy.

Benjamin Peirce, Proceedings of the American Academy of Arts and Sciences, vol. I, pp. 57-68, 144, 285, 338-41, etc. 


\section{CHAPTER XV}

SCIENCE AND TRAVEL - THE VOYAGE OF THE BEAGLE

Sir Charles Lyelu, in his Principles of Geology, the first edition of which appeared in 1830 1833, says: "If it be true that delivery be the first, second, and third requisite in a popular orator, it is no less certain that travel is of first, second, and third importance to those who desire to originate just and comprehensive views concerning the structure of our globe." The value of travel to science in general might very well be illustrated by Lyell's own career, his study of the mountainous regions of France, his calculation of the recession of Niagara Falls and of the sedimentary deposits of the Mississippi, his observations of the coal formations of Nova Scotia, and of the composition of the Great Dismal Swamp of Virginia - suggestive of the organic origin of the carboniferous rocks.

Although it is not with Lyell that we have here principally to deal, it is not irrelevant to say that the main purpose of his work was to show that all past changes in the earth's crust are referable to causes now in operation. Differing from Hutton as to the part played in those changes by subterranean heat, Lyell agreed with his forerunner in ascribing geological transformations to "the slow agency of existing causes." He was, in fact, the leader of the uniformitarians and opposed those geologists who 
held that the contemporary state of the earth's crust was owing to a series of catastrophes, stupendous exhibitions of natural force to which recent history offered no parallel. Also enlightened as to the significance of organic remains in stratified rock, Lyell in 1830 felt the need of further knowledge in reference to the relation of the plants and animals represented in the fossils to the fauna and flora now existing.

It is to Lyell's disciple, Charles Darwin, however, that we turn for our main illustration of the value of travel for comprehensive scientific generalization. Born, like another great liberator, on February 12, 1809 , Darwin was only twenty-two years old when he received appointment as naturalist on H.M.S. Beagle, about to sail from Devonport on a voyage around the world. The main purpose of the expedition, under command of the youthful Captain Fitzroy, three or four years older than Darwin, was to make a survey of certain coasts in South America and the Pacific Islands, and to carry a line of chronometrical measurements about the globe. Looking back in 1876 on this memorable expedition, the naturalist wrote, "The voyage of the Beagle has been by far the most important event in my life, and has determined my whole career." In spite of the years he had spent at school and college he regarded this experience as the first real training or education of his mind.

Darwin had studied medicine at Edinburgh, but found surgery distasteful. He moved to Cambridge, with the idea of becoming a clergyman of the Established Church. As a boy he had attended with his 
mother, daughter of Josiah Wedgwood, the Unitarian services. At Cambridge he graduated without distinction at the beginning of 1831 . It should be said, however, that the traditional studies were particularly ill suited to his cast of mind, that he had not been idle, and had developed particular diligence in different branches of science, and above all as a collector.

He was six feet tall, fond of shooting and hunting, and able to ride seventy-five or eighty miles without tiring. He had shown himself at college fond of company, and a little extravagant. He was, though a sportsman, extremely humane; had a horror of inflicting pain, and such repugnance at the thought of slavery that he quarreled violently with Captain Fitzroy when the latter condoned the abomination. Darwin was not, however, of a turbulent disposition. Sir James Sulivan, who had accompanied the expedition as second lieutenant, said many years after: "I can confidently express my belief that during the five years in the Beagle, he was never known to be out of temper, or to say one unkind or hasty word of or to any one."

Darwin's father was remarkable for his powers of observation, while the grandfather, Erasmus Darwin, is well known for his tendency to speculation. Charles Darwin possessed both these mental characteristics in an eminent degree. One who has conversed with him reports that what impressed him most in meeting the great naturalist was his clear blue eyes, which seemed to possess almost telescopic vision, and that the really remarkable thing about Darwin was that he saw more than other people. At 
the same time it will scarcely be denied that his vision was as much marked by insight as by careful observation, that his reasoning was logical and singularly tenacious, and his imagination vivid. It was before this supreme seer that the panorama of terrestrial creation was displayed during a five years' voyage.

No one can read Darwin's Journal descriptive of the voyage of the Beagle and continue to entertain any doubts in reference to his æsthetic sense and poetic appreciation of the various moods of nature. Throughout the voyage the scenery was for him the most constant and highest source of enjoyment. His emotions responded to the glories of tropical vegetation in the Brazilian forests, and to the sublimity of Patagonian wastes and the forest-clad hills of Tierra del Fuego. "It is easy," writes the gifted adolescent, " to specify the individual objects of admiration in these grand scenes; but it is not possible to give an adequate idea of the higher feelings of wonder, astonishment, and devotion, which fill and elevate the mind." Similarly, on the heights of the Andes, listening to the stones borne seaward day and night by the mountain torrents, Darwin remarked: "The sound spoke eloquently to the geologist; the thousands and thousands of stones, which striking against each other, made the one dull uniform sound, were all hurrying in one direction. It was like thinking on time, where the minute that now glides past is irrecoverable. So was it with these stones, the ocean is their eternity, and each note of that wild music told of one more step towards their destiny." 
When the Beagle left Devonport, December 27, 1831 , the young naturalist was without any theory, and when the ship entered Falmouth harbor, October 2,1836 , though he felt the need of a theory in reference to the relations of the various species of plants and animals, he had not formulated one. It was not till 1859 that his famous work on the Origin of Species appeared. He went merely as a collector, and frequently in the course of the voyage felt a young man's misgivings as to whether his collections would be of value to his Cambridge professors and other mature scientists.

Professor Henslow, the botanist, through whom Darwin had been offered the opportunity to accompany the expedition, had presented his pupil with the first volume of Lyell's Principles of Geology. (Perhaps, after Lyell, the most potent influence on Darwin's mind at this time was that of Humboldt and other renowned travelers, whose works he read with avidity.) At the Cape Verde Islands he made some interesting observations of a white calcareous stratum which ran for miles along the coast at a height of about forty-five feet above the water. It rested on volcanic rocks and was itself covered with basalt, that is, lava which had crystallized under the sea. It was evident that subsequently to the formation of the basalt that portion of the coast containing the white stratum had been elevated. The shells in the stratum were recent, that is, corresponded to those still to be found on the neighboring coast. It occurred to Darwin that the voyage might afford material for a book on geology. Later in the voyage, having read portions of his Journal to Captain 
Fitzroy, Darwin was encouraged to believe that this also might prove worthy of publication.

Darwin's account of his adventures and manifold observations is so informal, so rich in detail, as not to admit of summary. His eye took in the most diverse phenomena, the color of the sea or of rivers, clouds of butterflies and of locusts, the cacique with his little boy clinging to the side of a horse in headlong flight, the great earthquake on the coast of Chile, the endless variety of plant and animal life, the superstition of savage and padre, the charms of Tahiti, the unconscious humor of his mountain guides for whom at an altitude of eleven thousand feet " the cursed pot (which was a new one) did not choose to boil potatoes" - all found response in Darwin's open mind; everything was grist to his mill. Any selection from the richness of the original is almost sure to show a tendency not obvious in the Journal. On the other hand, it is just such multiplicity of phenomena as the Journal mirrors that impels every orderly mind to seek for causes, for explanation. The human intellect cannot rest till law gives form to the wild chaos of fact.

No disciple of Lyell could fail to be convinced of the immeasurable lapse of time required for the formation of the earth's crust. For this principle Darwin found abundant evidence during the years spent in South America. On the heights of the Andes he found marine shell fossils at a height of fourteen thousand feet above sea-level. That such an elevation of submarine strata should be achieved by forces still at Nature's command might well test the faith of the most ardent disciple. Of how great those 
forces are Darwin received demonstration on the coast of Chile in 1835. Under date of February 12, he writes: "This day has been memorable in the annals of Valdivia for the most severe earthquake experienced by the oldest inhabitant. ... A bad earthquake destroys our oldest associations; the earth, the very emblem of solidity, has moved beneath our feet like a thin crust over a fluid." $\mathrm{He}$ observed that the most remarkable effect of this earthquake was the permanent elevation of the land. Around the Bay of Concepcion it was raised two or three feet, while at the island of Santa Maria the elevation was much greater; "on one part Captain Fitzroy found beds of putrid mussel shells still adhering to the rocks, ten feet above high-water mark." On the same day the volcanoes of South America were active. The area from under which volcanic matter was actually erupted was 720 miles in one line and 400 in another at right angles to it. Great as is the force at work, ages are required to produce a range of mountains like the Cordilleras; moreover, progress is not uniform and subsidence may alternate with elevation. It was on the principle of the gradual subsidence (and elevation) of the bed of the Pacific Ocean that Darwin accounted for the formation of coral reefs. Nothing "is so unstable as the level of the crust of this earth."

Closely associated with the evidence of the immensity of the force of volcanic action and the infinitude of time elapsed, Darwin had testimony of the multitude of plant and animal species, some gigantic, others almost infinitely small, some living, others extinct. We know that his thought was greatly 
affected by his discovery in Uruguay and Patagonia of the fossil remains of extinct mammals, all the more so because they seemed to bear relationship to particular living species and at the same time to show likeness to other species. The Toxodon (bowtooth), for example, was a gigantic rodent whose fossil remains were discovered in the same region where Darwin found living the capybara, a rodent as large as a pig; at the same time the extinct species showed in its structure certain affinities to the Edentata (sloths, ant-eaters, armadillos). Other fossils represented gigantic forms distinctly of the edentate order and comparable to the Cape ant-eater and the Great Armadillo (Dasypus gigas). Again, remains were found of a thick-skinned non-ruminant with certain structural likeness to the Camelidæ, to which the living species of South American ruminants, the guanacos, belong.

Why have certain species ceased to exist? As the individual sickens and dies, so certain species become rare and extinct. Darwin found in Northern Patagonia evidence of the Equus curvidens, an extinct species of native American horse. What had caused this species to die out? Imported horses were introduced at Buenos Ayres in 1537, and so flourished in the wild state that in $\mathbf{1 5 8 0}$ they were found as far south as the Strait of Magellan. Darwin was well - fitted by the comprehensiveness of his observations to deal with the various factors of extinction and survival. He studied the species in their natural setting, the habitat, and range, and habits, and food of the different varieties. Traveling for three years and a half north and south on the continent of South 
America, he noticed one species replacing another, perhaps closely allied, species. Of the carrion-feeding hawks the condor has an immense range, but shows a predilection for perpendicular cliffs. If an animal die on the plain the polyborus has prerogative of feeding first, and is followed by the turkey buzzard and the gallinazo. European horses and cattle running wild in the Falkland Islands are somewhat modified; the horse as a species degenerating, the cattle increasing in size and tending to form varieties of different color. The soil being soft the hoofs of the horse grow long and produce lameness. Again, on the mainland, the niata, a breed of cattle supposed to have originated among the Indians south of the Plata, are, on account of the projection of the lower jaw, unable to browse as effectually as other breeds. This renders them liable to destruction in times of drought. A similar variation in structure had characterized a species of extinct ruminant in India.

How disastrous a great drought might prove to the cattle of the Pampas is shown by the records of 1825 and of 1830 . So little rain fell that there was a complete failure of vegetation. The loss of cattle in one province alone was estimated at one million. Of one particular herd of twenty thousand not a single one survived. Darwin had many other instances of nature's devastations. After the Beagle sailed from the Plata, December 6, 1833, vast numbers of butterflies were seen as far as the eye could range in bands of countless myriads. "Before sunset a strong breeze sprung up from the north, and this must have caused tens of thousands of the butterflies and other 
insects to perish." Two or three months before this he had ocular proof of the effect of a hailstorm, which in a very limited area killed twenty deer, fifteen ostriches, numbers of ducks, hawks, and partridges. In the war of extermination that was ever before the great naturalist's eye in South America, what is it that favors a species' survival or determines its extinction?

Not only is the struggle between the animals and inanimate nature, the plants and inanimate nature, plant and animal, rival animals, and rival plants; it goes on between man and his environment, and, very fiercely, between man and man. Darwin was moved by intense indignation at the slavery on the east coast and the cruel oppression of the laborer on the west coast. He was in close contact with the sanguinary political struggles of South America, and with a war of attempted extermination against the Indian. He refers to the shocking but " unquestionable fact, that [in the latter struggle] all the women who appear above twenty years old are massacred in cold blood! When I exclaimed that this appeared rather inhuman, he [the informant] answered, 'Why, what can be done? they breed so!",

In all his travels nothing that Darwin beheld made a deeper impression on his sensitive mind than primitive man. "Of individual objects, perhaps nothing is more certain to create astonishment than the first sight in his native haunt of a barbarian - of man in his lowest and most savage state. One's mind hurries back over past centuries, and then asks, could our progenitors have been men like these? . . . I do not believe it is possible to describe or paint the dif- 
ference between savage and civilized man." It was at Tierra del Fuego that he was particularly shocked. He adınired the Tahitians; he pitied the natives of Tasmania, corralled like wild animals and forced to migrate; he thought the black aborigines of Australia had been underestimated and remarked with regret that their numbers were decreasing through their association with civilized man, the introduction of spirits, the increased difficulty of procuring food, and contact with European diseases. In this last cause tending to bring about extinction there was a mysterious element. In Chile his scientific acumen had been baffled in the attempt to explain the invasion of the strange and dreadful disease bydrophobia. In Australia the problem of the transmission to the natives of various diseases, even by Europeans in apparent health, confronted his intelligence. "The varieties of man seem to act on each other in the same way as different specimens of animals - the stronger always extirpating the weaker."

It was at Wollaston Island, near Cape Horn, however, that Darwin saw savage men held in extremity by the hard conditions of life, and at bay. They had neither food, nor shelter, nor clothing. They stood absolutely naked as the sleet fell on them and melted. At night, "naked and scarcely protected from the wind and rain of this tempestuous climate," they slept on the wet ground coiled up like animals. They subsisted on shell fish, putrid whale's blubber, or a few tasteless berries and fungi. At war, the different tribes are cannibals. Darwin writes, "It is certainly true, that when pressed in winter by hunger, they kill and devour their old women before they kill their 
dogs." A native boy, when asked by a traveler why they do this, had answered, "Doggies catch otters, old women no." In such hard conditions what are the characteristics that would determine the survival of individual or tribe? One might be tempted to lay almost exclusive emphasis on physical strength, but Darwin was too wise ultimately to answer thus the question that for six or seven years was forming in his accurate and discriminating mind.

On its way west in the Pacific the Beagle spent a month at the Galapagos Archipelago, which lies under the equator five or six hundred miles from the mainland. "Most of the organic productions are aboriginal creations, found nowhere else; there is even a difference between the inhabitants of the different islands; yet all show a marked relationship with those of America." Why should the plants and animals of the islands resemble those of the mainland, or the inhabitants of one island differ from those of a neighboring island? Darwin had always held that species were created immutable, and that it was impossible for one species to give rise to another.

In the Galapagos Archipelago he found only one species of terrestrial mammal, a new species of mouse, and that only on the most easterly island of the group. On the South American continent there were at least forty species of mice, those east of the Andes being distinct from those on the west coast. Of land-birds he obtained twenty-six kinds, twenty-five of which were to be found nowhere else. Among these, a hawk seemed in structure intermediate between the buzzard and polyborus, as though it had been modified and induced to take over the functions of the South Ameri- 
can carrion-hawk. There were three species of mocking-thrush, two of them confined to one island each. There were thirteen species of finches, all peculiar to the archipelago. In the different species of geospiza there is a perfect gradation in the size of the beaks, only to be appreciated by seeing the specimens or their illustrations.

Few of the birds were of brilliant coloration. The same was true of the plants and insects. Darwin looked in vain for one brilliant flower. This was in marked contrast to the fauna and flora of the South American tropics. The coloration of the species suggested comparison with that of the plants and animals of Patagonia. Amid brilliant tropical plants brilliant plumage may afford means of concealment, as well as being a factor in the securing of mates.

Darwin found the reptiles the most striking feature of the zoölogy of the islands. They seem to take the place of the herbivorous mammalia. The huge tortoise (Testudo nigra) native in the archipelago is so heavy as to be lifted only by six or eight men. (The young naturalist frequently got on the back of a tortoise, but as it moved forward under his encouragement, he found it very difficult to keep his balance.) Different varieties, if not species, characterize the different islands. Of the other reptilia should be noted two species of lizard of a genus (Amblyrhynchus) confined to the Galapagos Islands. One, aquatic, a yard long, fifteen pounds in weight, with "limbs and strong claws admirably adapted for crawling over the rugged and fissured masses of lava," feeds on seaweed. When frightened it instinctively shuns the water, as though it feared especially its 
aquatic enemies. The terrestrial species is confined to the central part of the group; it is smaller than the aquatic species, and feeds on cactus, leaves of trees, and berries.

Fifteen new species of sea-fish were obtained, distributed in twelve genera. The archipelago, though not rich in insects, afforded several new genera, each island with its distinct kinds. The flora of the Galapagos Islands proved equally distinctive. More than half of the flowering plants are native, and the species of the different islands show wonderful differences. For example, of seventy-one species found on James Island thirty-eight are confined to the archipelago and thirty to this one island.

In October the Beagle sailed west to Tahiti, New Zealand, Australia, Keeling or Cocos Islands, Mauritius, St. Helena, Ascension ; arrived at Bahia, Brazil, August 1, 1836 ; and finally proceeded from Brazil to England. Among his many observations, Darwin noted the peculiar animals of Australia, the kangaroo-rat, and "several of the famous Ornithorhynchus paradoxus," or duckbill. On the Keeling or Cocos Islands the chief vegetable production is the cocoanut. Here Darwin observed crabs of monstrous size, with a structure which enabled them to open the cocoanuts. They thus secured their food, and accumulated "surprising quantities of the picked fibres of the cocoanut husk, on which they rest as a bed."

In preparing his Journal for publication in the autumn of 1836 the young naturalist saw how many facts pointed to the common descent of species. $\mathrm{He}$ thought that by collecting all facts that bore on the 
variation of plants and animals, wild or domesticated, light might be thrown on the whole subject. "I worked on true Baconian principles, and, without any theory, collected facts on a wholesale scale." $\mathrm{He}$ saw that pigeon-fanciers and stock-breeders develop certain types by preserving those variations that have the desired characteristics. This is a process of artificial selection. How is selection made by Nature?

In 1838 he read Malthus' Essay on the Principle of Population, which showed how great and rapid, without checks like war and disease, the increase in number of the human race would be. $\mathrm{He}$ had seen something in his travels of rivalry for the means of subsistence. He now perceived "that under these circumstances favorable variations would tend to be preserved, and unfavorable ones to be destroyed. The results of this would be the formation of a new species." As special breeds are developed by artificial selection, so new species evolve by a process of natural selection. Those genera survive which give rise to species adapted to new conditions of existence.

In 1858, before Darwin had published his theory, he received from another great traveler, Alfred Russel Wallace, then at Termate in the Moluccas, a manuscript essay, setting forth an almost identical view of the development of new species through the survival of the fittest in the struggle for existence. 


\section{THE HISTORY OF SCIENCE}

\section{REFERENCES}

Charles Darwin, A Naturalist's Journal.

Francis Darwin, The Life and Letters of Charles Darwin.

W. A. Locy, Biology and its Makers (third revised edition), chap. XIX.

G. J. Romanes, Darwin and After Darwin, vol. I.

A. R. Wallace, Darwinism.

See also John W. Judd, The Coming of Evolution (The Cambridge

Manuals of Science and Literature). 


\section{CHAPTER XVI}

\section{SCIENCE AND WAR - PASTEUR, LISTER}

IN the history of science war is no mere interruption, but a great stimulating influence, promoting directly or indirectly the liberties of the people, calling into play the energy of artisan and manufacturer, and increasing the demand for useful and practical studies. In the activities of naval and military equipment and organization this influence is obvious enough; it is no less real in the reaction from war which impels all to turn with new zest to the arts and industries of peace and to cherish whatever may tend to culture and civil progress. Not infrequently war gives rise, not only to new educational ideals, but to new institutions and to new types of institution favorable to the advancement of science. As we have already seen, the Royal Society and Milton's Academies owed their origin to the Great Rebellion. Similarly the Ecole Polytechnique, mother of many scientific discoveries, rose in answer to the needs of the French Revolution. Noless noteworthy was the reconstruction of education under the practical genius of Napoleon I, the division of France into académies, the founding of the lycées, the reëstablishment of the great Ecole Normale, and the organization of the Imperial University with new science courses and new provincial Faculties at Rennes, Lille, and elsewhere. With all these different forms in which the influence of war makes itself felt in the progress of science 
the life and career of Louis Pasteur (1822-1895), the founder of bacteriology, stood intimately associated.

He was born at Dôle, but the family a few years later settled at Arbois. For three generations the Pasteurs had been tanners in the Jura, and they naturally adhered to that portion of the population which hailed the Revolution as a deliverance. The great-grandfather was the first freeman of Pasteur's forbears, having purchased with money his emancipation from serfdom. The father in 1811, at the age of twenty, was one of Napoleon's conscripts, and in 1814 received from the Emperor, for valor and fidelity, the Cross of the Legion of Honor. The directness and endurance of the influence of this trained veteran on his gifted son a hundred fine incidents attest. In 1848 - year of revolt in the monarchies of Europe - the young scientist enrolled himself in the National Guard, and, seeing one day in the Place du Panthéon a structure inscribed with the words autel de la patrie, he placed upon it all the humble means - one hundred and fifty francs - then at his disposal.

It was in that same year that Pasteur put on record his discovery of the nature of racemic acid, his first great service to science, from which all his other services were to proceed. As a boy he had attended the collège at Arbois where his teacher had inspired him with an ambition to enter the great Ecole Normale. Before reaching that goal he took his bachelor's degree in science as well as in arts at the Besançon college. At Paris he came in contact with the leaders of the scientific world - Claude Bernard, Balard, Dumas, Biot. 
J. B. Biot had entered the ranks of science by way of the Ecole Polytechnique and the artillery service. In 1819 he had announced that the plane of polarized light - for example, a ray passed through Iceland spar - is deflected to right or left by various chemical substances. Among these is common tartaric acid - the acid of grape-juice, obtained from wine lees. Racemic acid, however, which is identical with tartaric acid in its chemical constituents, is optically inactive, rotating the plane of polarized light neither to the right nor the left. This substance Pasteur subjected to special investigation. He scrutinized the crystals of sodium ammonium racemate obtained from aqueous solution. These he observed to be of two kinds differing in form as a right glove from a left, or as an object from its mirror-image. Separating the crystals according to the difference of form, he made a solution from each group. One solution, tested in the polarized-light apparatus, turned the plane to the right; the other solution turned it to the left. He had made a capital discovery of far-reaching importance, namely, that racemic acid is composite, consisting of dextro-tartaric and lævo-tartaric acids. Biot hesitated to credit a mere tyro with such an achievement. The experiment was repeated in his presence. Convinced by ocular demonstration, he was almost overcome with emotion. "My dear boy," he exclaimed, "I have loved the sciences so much my life through that that makes my heart jump."

Pasteur began his regular professional experience as a teacher of physics in the Dijon lycée, but he was soon transferred to the University of Strasburg (1849). There he married the daughter of the 
rector of the académie, and three years later became Professor of Chemistry. In 1854 he was appointed Dean of the Faculty of Sciences at Lille, a town then officially described as the richest center of industrial activity in the north of France. In his opening address he showed the value and attractiveness of practical studies. He believed as an educator in the close alliance of laboratory and factory. Application should always be the aim, but resting on the severe and solid basis of scientific principles; for it is theory alone which can bring forth and develop the spirit of invention.

His own study of racemic acid, begun in the laboratories of Paris, and followed up in the factories of Leipzig, Prag, and Vienna, had led to his theory of molecular dissymmetry, the starting point of modern stereo-chemistry. It now gave rise on Pasteur's part to new studies and to new applications to the industries. He tried an experiment which seems almost whimsical, placing ammonium racemate in the ordinary conditions of fermentation, and observed that only one part - the dextro-rotatory - ferments or putrefies. Why? "Because the ferments of that fermentation feed more easily on the right hand than on the left hand molecules." He succeeded in keeping alive one of the commonest moulds on the surface of ashes and racemic acid, and saw the lævotartaric acid appear. It was thus that he passed from the study of crystals to the study of ferments.

In the middle of the nineteenth century little was known of the nature of fermentation, though some sought to explain by this ill-understood process the origin of various diseases and of putrefaction. Why 
does fruit-juice produce alcohol, wine turn to vinegar, milk become sour, and butter rancid? Pasteur's interest in these problems of fermentation was stimulated by one of the industries of Lille. He was accustomed to visit with his students the factories of that place as well as those of neighboring French and Belgian cities. The father of one of his students was engaged in the manufacture of alcohol from beetroot sugar, and Pasteur came to be consulted when difficulties arose in the manufacturing process. He discovered a relationship between the development of the yeast and the success or failure of the fermentation, the yeast globules as seen under the microscope showing an alteration of form when the fermentation was not proceeding satisfactorily. In 1857 Pasteur on the basis of this study was able to demonstrate that alcoholic fermentation, that is, the conversion of sugar into alcohol, carbonic acid, and other compounds, depends on the action of yeast, the cells of which are widely disseminated in the atmosphere.

In this year of his second great triumph Pasteur was appointed director of science studies in the Ecole Normale, from which he had graduated in 1847. Two years later the loss of his daughter by a communicable disease - typhoid fever - had a great effect on his sensitive and profound mind. Many of his opponents, it is true, found Pasteur implacable in controversy. Undoubtedly he had the courage of his convictions, and his belief that, for the sake of human welfare, right views - his views won by tireless experiment - must prevail, gained him the name of a fighter. But in all the intimate relations of life his essential tenderness was manifest. Like Darwin 
he had a horror of inflicting pain, and always insisted, when operations on animals were necessary in the laboratory, on the use of anæsthetics (our command of which had been greatly advanced by Simpson in 1847). Emile Roux said that Pasteur's agitation at witnessing the slightest exhibition of pain would have been ludicrous if, in so great a man, it had not been touching.

A few months after his daughter's death Pasteur wrote to one of his friends: "I am pursuing as best I can these studies on fermentation, which are of great interest, connected as they are with the impenetrable mystery of life and death. I am hoping to make a decisive advance very soon, by solving without the least lack of clearness the famous question of spontaneous generation." Two years previously a scientist had claimed that animals and plants could be generated in a medium of artificial air or oxygen, from which all atmospheric air and all germs of organized bodies had been precluded. Pasteur now filtered atmospheric air through a plug of cotton or asbestos (a procedure which had been followed by others in 1854), and proved that in air thus treated no fermentation takes place. Nothing in the atmosphere causes life except the micro-organisms it contains. He even demonstrated that a putrescible fluid like blood will remain unchanged in an open vessel so constructed as to exclude atmospheric dust.

Pasteur's critics maintained that if putrefaction and fermentation be caused solely by microscopic organisms, then these must be found everywhere and in such quantities as to encumber the air. He replied 
that they were less numerous in some parts of the atmosphere than in others. To prove his contention he set out for Arbois with a large number of glass bulbs each half filled with a putrescible liquid. The necks of the bulbs had been drawn out and hermetically sealed after the contents had been boiled. In case the necks were broken (to be again sealed immediately), the air would rush in, and (if it held the requisite micro-organisms) furnish the conditions for putrefaction. It was found that in every trial the contents of a certain number of the bulbs always escaped alteration. Twenty were opened in the country near Arbois free from human habitations. Eight out of the twenty showed signs of putrefaction. Twenty were exposed to the air on the heights of the Jura at an altitude of eight hundred and fifty meters above sea-level; the contents of five of these subsequently putrefied. Twenty others were opened near Mont Blanc at an altitude of two thousand meters and while a wind was blowing from the Mer de Glace; in this case the contents of only one of the bulbs became putrefied.

While his opponents still professed to believe in the creation of organized beings lacking parents, Pasteur was under the influence of the theory of "the slow and progressive transformation of one species into another," and was becoming aware of phases of the struggle for existence hitherto shrouded in mystery. He wished he said to push these studies far enough to prepare the way for a serious investigation of the origin of disease.

He returned to the study of lactic fermentation, showed that butyric fermentation may be caused by 
organisms which live in the absence of oxygen, while vinegar is produced from wine through the agency of bacteria freely supplied with the oxygen of the air. Pasteur was seeing ever more clearly the part played by the infinitesimally small in the economy of nature. Without these microscopic beings life would become impossible, because death would be incomplete. On the basis of Pasteur's study of fermentation, his demonstration that decomposition is owing to living organisms and that minute forms of life spring from parents like themselves, his disciple Joseph Lister began in 1864 to develop antiseptic surgery.

Pasteur's attention was next directed to the wine industry, which then had an annual value to France of 500,000,000 franes. Might not the acidity, bitterness, defective flavor, which were threatening the foreign sale of French wines, be owing to ferments? $\mathrm{He}$ discovered that this was, indeed, the case, and that the diseases of wine could be cured by the simple expedient of heating the liquor for a few moments to a temperature of $50^{\circ}$ to $60^{\circ} \mathrm{C}$. Tests on a considerable scale were made by order of the naval authorities. The ship Jean Bart before starting on a voyage took on board five hundred liters of wine, half of which had been heated under Pasteur's directions. At the end of ten months the pasteurized wine was mellow and of good color, while the wine which had not been heated had an astringent, almost bitter, taste. A more extensive test - seven hundred hectoliters, of which six hundred and fifty had been pasteurized - was carried out on the frigate la Sibylle with satisfactory results. Previously wines 
had been preserved by the addition of alcohol, which made them both dearer and more detrimental to health.

In 1865 Pasteur was called upon to exercise his scientific acumen on behalf of the silk industry. A disease - pébrine - had appeared among silkworms in 1845. In 1849 the effect on the French industry was disastrous. In the single arrondissement of Alais an annual income of $120,000,000$ franes was lost for the subsequent fifteen years. The mulberry plantations of the Cévennes were abandoned and the whole region was desolate. Pasteur, at the instigation of the Minister of Agriculture, undertook an investigation. After four or five years, in spite of repeated domestic afflictions and the breakdown of his own health, he arrived at a successful conclusion. Pébrine, due to "corpuscles" readily detected under the microscope, could be recognized at the moment of the moth's formation. A second disease, flacherie, was due to a micro-organism found in the digestive cavity of the moth. Measures were taken to select the seed of the healthy moths and to destroy the others. These investigations revealed the infinitesimally small as disorganizers of living tissue, and brought Pasteur nearer his purpose "of arriving," as he had expressed it to Napoleon III in 1863, "at the knowledge of the causes of putrid and contagious diseases."

Returning in July, 1870, from a visit to Liebig at Munich, Pasteur heard at Strasburg of the imminence of war. All his dreams of conquest over disease and death seemed to vanish. He hurried to Paris. His son, eighteen years of age, set out with 
the army. Every student of the Ecole Normale enlisted. Pasteur's laboratory was used to house soldiers. He himself wished to be enrolled in the $\mathrm{Na}$ tional Guard, and had to be told that a half-paralyzed man could not render military service. He was obsessed with horror of wanton bloodshed and with indignation at the insolence of armed injustice. Trained to serve his country only in one way he tried, but in vain, to resume his researches. He retired to the old home town of Arbois, and sought to distract his mind from the contemplation of human baseness. Arbois was entered by the enemy in January with the usual atrocities of war. Pasteur accompanied by wife and daughter had gone in search of his son, sick at Pontarlier. The boy was restored to health and returned to his regiment the following month.

During this crisis Pasteur and his friends felt, as many English scientists feel in 1917, in reference to ignorance in high places. "We are paying the penalty," he said, "of fifty years' forgetfulness of science, and of its conditions of development." Again he speaks, as Englishmen to-day very well might, of the neglect, disdain even, of the country for great intellectual men, especially in the realm of exact science. In the same strain his friend Bertin said that after the war everything would have to be rebuilt from the top to the bottom, the top especially. Pasteur recalled the period of 1792 when Lavoisier, Berthollet, Monge, Fourcroy, Guyton de Morveau, Chaptal, Clouet, and other scientists had furnished France with gunpowder, steel, cannon, fortifications, balloons, leather, and other means to repel unjust invasion. 
On the day after Sedan the Quaker surgeon Lister had published directions for the use of aqueous solutions of carbolic acid to destroy septic particles in wounds, and of oily solutions "to prevent putrefactive fermentation from without." He recognized that the earlier the case comes from the field the greater the prospect of success. Sédillot (the originator of the term "microbe"), at the head of an ambulance corps in Alsace, was a pioneer in the rapid transport of wounded from the field of battle. He knew the horrors of purulent infection in military hospitals, and regretted that the principles of Pasteur and Lister were not more fully applied.

After the war was over, Pasteur kept repeating his life-long exhortation: We must work - "Travaillez, travaillez toujours !" He applied himself to a study of the brewing industry. He did not believe in spontaneous alterations, but found that every marked change in the quality of beer coincides with the development of micro-organisms. He was able to tell the English brewers the defects in their output by a microscopic examination of their yeast. ("We must make some friends for our beloved France," he said.) Bottled beer could be pasteurized by bringing it to a temperature of $50^{\circ}$ to $55^{\circ} \mathrm{C}$. Whenever beer contains no ferments it is unalterable. His scrupulous mind was coming ever closer to the goal of his ambition. This study of the diseases of beer led him nearer to a knowledge of infections. Many micro-organisms may, must, be detrimental to the health of man and animals.

In 1874 the Government conferred upon Pasteur a life annuity of twelve thousand francs, an equiva- 
lent of his salary as Professor of Chemistry at the Sorbonne. (He had received appointment in 1867, but had been compelled by ill-health to relinquish his academic functions.) The grant was in all respects wise. Huxley remarked that Pasteur's discoveries alone would suffice to cover the war indemnity of five milliards paid by France to Germany in 1871 . Moreover, all his activities were dictated by patriotic motives. He felt that science is of no country and that its conquests belong to mankind, but that the scientist must be a patriot in the service of his native land.

Pasteur now applied his energies to the study of virulent diseases, following the principles of his earlier investigations. He opposed those physicians who believed in the spontaneity of disease, and he wished to wage a war of extermination against all injurious organisms. As early as 1850 Davaine and Rayer had shown that a rod-like micro-organism was always present in the blood of animals dying of anthrax, a disease which was destroying the flocks and herds of France. Dr. Koch, who had served in the FrancoPrussian War, succeeded in 1876 in obtaining pure cultures of this bacillus and in defining its relation to the disease. Pasteur took up the study of anthrax in 1877, verified previous discoveries, and, as we shall see, sought means for the prevention of this pest. He discovered (with Joubert and Chamberland) the bacillus of malignant edema. $\mathrm{He}$ applied the principles of bacteriology to the treatment of puerperal fever, which in 1864 had rendered fatal 310 cases out of 1350 confinements in the Maternité in Paris. Here he had to fight against conservatism in the 
medical profession, and he fought strenuously, one of his disciples remarking that it is characteristic of lofty minds to put passion into ideas. Swine plague, which in the United States in 1879 destroyed over a million hogs, and chicken cholera, also engaged his attention.

Cultures of chicken cholera virus kept for some time became less active. A hen that chanced to be inoculated with the weakened virus developed the disease, but, after a time, recovered (much as patients after the old-time smallpox inoculations). It was then inoculated with a fresh culture supposed sufficient to cause death. It again recovered. The use of the weakened inoculation had developed its resistance to infection. A weakened virus recovered its strength when passed through a number of sparrows, the second being inoculated with virus from the first, the third from the second, and so on (this species being subject to the disease). Hens that had not had chicken cholera could be rendered immune by a series of attenuated inoculations gradually increasing in strength. In the case of anthrax the virus could be weakened by keeping it at a certain temperature, while it could be strengthened by passage through a succession of guinea-pigs. There are of course many instances where pathogenic bacteria lose virulence in passing from one animal to another, the human smallpox virus, for example, producing typical cowpox in an inoculated heifer. These facts help to explain why certain infections have grown less virulent in the course of history, and why infections of which civilized man has become tolerant prove fatal when imparted to the primitive peoples of Australia. 
Pasteur's preventive inoculation for anthrax was tested under dramatic circumstances at Melun in June, 1881. Sixty sheep and a number of cows were subjected to experiment. None of the sheep that had been given the preventive treatment died from the crucial inoculation; while all those succumbed which had not received previous treatment. The test for the cows was likewise successful. Pasteur thought that in places where sheep dead of anthrax had been buried, the microbes were brought to the surface in the castings of earthworms. Hence he issued certain directions to prevent the transmission of the disease. $\mathrm{He}$ also aided agriculture by discovering a vaccine for swine plague.

When Pasteur at the age of fifteen was in Paris, overcome with homesickness, he had exclaimed, "If I could only get a whiff of the old tannery yard, I feel I should be cured." Certainly every time he came in contact with the industries - silk, wine, beer, wool - his scientific insight, Antæus-like, seemed to revive. All his life he had preached the doctrine of interchange of service between theory and practice, science and the occupations. What he did is more eloquent than words. His theory of molecular dissymmetry, that the atoms in a molecule may be arranged in left-hand and right-hand spirals or other tridimensional figures corresponding to asymmetrical crystals, touches the abstruse question of the constitution of matter. His preventive treatment breathes new life into the old dictum similia similibus curantur. The view he adopted of the gradual transformation of species offers a new interpretation of the speculations of philosophy in reference to being and 
becoming and the relation of the real to the concrete. Yet Pasteur felt he could learn much of value from the simplest shepherd or vine-dresser.

He was complete in the simplicity of his affections, in his compassion for all suffering, in the warmth of his religious faith, and in his devotion to his country. He thought France was to regain her place in the world's esteem through scientific progress. He was therefore especially gratified in $\mathrm{Au}$ gust, 1881, at the thunders of applause which greeted his appearance at the International Medical Congress in London. There he was introduced to the Prince of Wales (fondateur de l'Entente Cordiale), "to whom I bowed, saying that I was happy to salute a friend of France."

Pasteur's investigation of rabies began in this same year. Difficulty was found in isolating the microbe of the rabic virus, but an inoculation from the medulla oblongata of a mad dog injected into one of the brain membranes (dura mater) of another dog invariably. brought on the symptoms of rabies. To obtain attenuation of the virus it was sufficient to dry the medulla taken from an infected rabbit. The weakened virus increased in strength when cultivated in a series of rabbits. Pasteur oktained in inoculations of graded virulence, which could be administered hypodermically, a means of prophylaxis after bites. He conjectured that in vaccinal immunity the virus is accompanied by a substance which makes the nervous tissue unfavorable for the development of the microbe.

It was not till 1885 that he ventured to use his discovery to prevent hydrophobia. On July 6 a little 
boy, Joseph Meister, from a small place in Alsace was brought by his mother to Paris for treatment. He had been severely bitten by a mad dog. Pasteur, with great trepidation, but moved by his usual compassion, undertook the case. The inoculations of the attenuated virus began at once. The boy suffered little inconvenience, playing about the laboratory during the ten days the treatment lasted. Pasteur was racked with fears alternating with hopes, his anxiety growing more intense as the virulence of the inoculations increased. On August 20, however, even he was convinced that the treatment was a complete success. In October a shepherd lad, who, though badly bitten himself, had saved some other children from the attack of a rabid dog, was the second one to benefit by the great discovery. Pasteur's exchange of letters with these boys after they had returned to their homes reveals the kindliness of his disposition. His sentiment toward children had regard both to what they were and to what they might become. One patient, brought to him thirty-seven days after being bitten, he failed to save. By March 1 Pasteur reported that three hundred and fifty cases had been treated with only one death.

When subscriptions were opened for the erection and endowment of the Pasteur Institute, a sum of $2,586,680$ francs was received in contributions from many different parts of the world. Noteworthy among the contributors were the Emperor of Brazil, the Czar of Russia, the Sultan of Turkey, and the peasants of Alsace. On November 14, 1888, President Carnot opened the institution, which was soon 
to witness the triumphs of Roux, Yersin, Metchnikoff, and other disciples of Pasteur. In the address prepared for this occasion the veteran scientist wrote:

"If I might be allowed, M. le Président, to conclude by a philosophical remark, inspired by your presence in this home of work, I should say that two contrary laws seem to be wrestling with each other at the present time; the one a law of blood and death, ever devising new means of destruction and forcing nations to be constantly ready for the battlefield - the other, a law of peace, work, and health, ever developing new means of delivering man from the scourges which beset him.

"The one seeks violent conquests, the other the relief of humanity. The latter places one human life above any victory; while the former would sacrifice hundreds and thousands of lives to the ambition of one. The law of which we are the instruments seeks, even in the midst of carnage, to cure the sanguinary ills of the law of war; the treatment inspired by our antiseptic methods may preserve thousands of soldiers. Which of these two laws will ultimately prevail God alone knows. But we may assert that French science will have tried, by obeying the law of humanity, to extend the frontiers of life." 


\section{REFERENCES}

W. W. Ford, The Life and Work of Robert Koch, Bulletin of the Johns Hopkins Hospital, Dec. 1911, vol. 22.

C. A. Herter, The Influence of Pasteur on Medical Science, Bulletin of the Johns Hopkins Hospital, Dec. 1903, vol. 14.

E. O. Jordan, General Bacteriology (fourth edition, 1915).

Charles C. W. Judd, The Life and Work of Lister, Bulletin of the Johns Hopkins Hospital, Oct. 1910, vol. 21.

Stephen Paget, Pasteur and After Pasteur.

W. T. Sedgwick, Principles of Sanitary Science.

René Vallery-Radot, Life of Pasteur. 


\section{CHAPTER XVII}

\section{SCIENCE AND INVENTION - LANGLEY'S AEROPLANE}

Is his laudation of the nineteenth century Alfred Russel Wallace ventured to enumerate the chief inventions of that period: (1) Railways; (2) steam navigation; (3) electric telegraphs; (4) the telephone; (5) friction matches; (6) gas-lighting; (7) electric-lighting; (8) photography; (9) the phonograph; (10) electric transmission of power; (11) Röntgen rays; (12) spectrum analysis; (13) anæstheties; (14) antiseptic surgery. All preceding centuries - less glorious than the nineteenth can claim but seven or eight capital inventions: (1) Alphabetic writing; (2) Arabic numerals; (3) the mariner's compass; (4) printing; (5) the telescope; (6) the barometer and thermometer; (7) the steam engine. Similarly, to the nineteenth century thirteen important theoretical discoveries are ascribed, to the eighteenth only two, and to the seventeenth five.

Of course the very purpose of these lists - namely, to compare the achievements of one century with those of other centuries - inclines us to view each invention as an isolated phenomenon, disregarding its antecedents and its relation to contemporary inventions. Studied in its development, steam navigation is but an application of one kind of steam engine, and, moreover, must be viewed as a 
phase in the evolution of navigation since the earliest times. Like considerations would apply to railways, antiseptic surgery, or friction matches. The nineteenth-century inventor of the friction match was certainly no more ingenious (considering the means that chemistry had put at his disposal) than many of the savages who contributed by their intelligence to methods of producing, maintaining, and using fire. In fact, as we approach the consideration of prehistoric times it becomes difficult to distinguish inventions from the slow results of development - in metallurgy, tool-making, building, pottery, war-gear, weaving, cooking, the domestication of animals, the selection and cultivation of plants. Moreover, it is scarcely in the category of invention that the acquisition of alphabetic writing or the use of Arabic numerals properly belongs.

These and other objections, such as the omission of explosives, firearms, paper, will readily occur to the reader. Nevertheless, these lists, placed side by side with the record of theoretic discoveries, encourage the belief that, more and more, sound theory is productive of useful inventions, and that henceforth it must fall to scientific endeavor rather than to lucky accident to strengthen man's control over Nature. Even as late as the middle of the nineteenth century accident and not science was regarded as the fountain-head of invention, and the view that a knowledge of the causes and secret motions of things would lead to "the enlarging of the bounds of human empire to the effecting of all things possible" was scouted as the idle dream of a doctrinaire.

In the year 1896 three important advances were 
made in man's mastery of his environment. These are associated with the names of Marconi, Becquerel, and Langley. It was in this year that the last-named, long known to the scientific world for his discoveries in solar physics, demonstrated in the judgment of competent witnesses the practicability of mechanical flight. This was the result of nine years' experimentation. It was followed by several more years of fruitful investigation, leading to that ultimate triumph which it was given to Samuel Pierpont Langley to see only with the eye of faith.

The English language has need of a new word ("plane") to signify the floating of a bird upon the wing with slight, or no, apparent motion of the wings (planer, schweben). To hover has other connotations, while to soar is properly to fly upward, and not to hang poised upon the air. The miracle of a bird's flight, that steady and almost effortless motion, had interested Langley intensely — as had also the sun's radiation - from the years of his childhood. The phenomenon (the way of an eagle in the air) has always, indeed, fascinated the human imagination and at the same time baffled the comprehension. The skater on smooth ice, the ship riding at sea, or even the fish floating in water, offers only an incomplete analogy; for the fish has approximately the same weight as the water it displaces, while a turkey buzzard of two or three pounds' weight will circle by the half-hour on motionless wing upheld only by the thin medium of the air.

In 1887, prior to his removal to Washington as Secretary of the Smithsonian Institution, Langley began his experiments in aerodynamics at the old 
observatory in Allegheny - now a part of the city of Pittsburgh. His chief apparatus was a whirling table, sixty feet in diameter, and with an outside speed of seventy miles an hour. This was at first driven by a gas engine, - ironically named "Automatic," - for which a steam engine was substituted in the following year. By means of the whirling table and a resistance-gauge (dynamometer chronograph) Langley studied the effect of the air on planes of varying lengths and breadths, set at varying angles, and borne horizontally at different velocities. At times he substituted stuffed birds for the metal planes, on the action of which under air pressure his scientific deductions were based. In 1891 he published the results of his experiments. These proved - in opposition to the teaching of some very distinguished scientists - that the force required to sustain inclined planes in horizontal locomotion through the air diminishes with increased velocity (at least within the limits of the experiment). Here a marked contrast is shown between aerial locomotion on the one hand, and land and water locomotion on the other; "whereas in land or marine transport increased speed is maintained only by a disproportionate expenditure of power, within the limits of experiment in such aerial horizontal transport, the higher speeds are more economical of power than the lower ones." Again, the experiments demonstrated that the force necessary to maintain at high velocity an apparatus consisting of planes and motors could be produced by means already available. It was found, for example, that one horse-power rightly applied is sufficient to maintain a plane of two hundred pounds in 
horizontal flight at a rate of about forty-five miles an hour. Langley had in fact furnished experimental proof that the aerial locomotion of bodies many times heavier than air was possible. He reserved for further experimentation the question of aerodromics, the form, ascent, maintenance in horizontal position, and

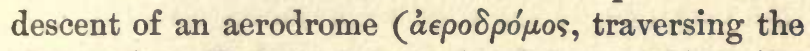
air), as he called the prospective flying machine. He believed, however, that the time had come for seriously considering these things, and intelligent physicists, who before the publication of Langley's experiments had regarded all plans of aerial navigation as utopian, soon came to share his belief. According to Octave Chanute there was in Europe in 1889 utter disagreement and confusion in reference to fundamental questions of aerodynamics. He thought Langley had given firm ground to stand upon concerning air resistances and reactions, and that the beginning of the solution of the problem of aerial navigation would date from the American scientist's experiments in aerodynamics.

Very early in his investigations Langley thought he received through watching the anemometer a clue to the mystery of flight. Observations, begun at Pittsburgh in 1887 and continued at Washington in 1893, convinced him that the course of the wind is "a series of complex and little-known phenomena," and that a wind to which we may assign a mean velocity of twenty or thirty miles an hour, even disregarding the question of strata and currents, is far from being a mere mass movement, and consists of pulsations varying both in rate and direction from second to second. If this complexity is revealed by the stationary 
anemometer - which may register a momentary calm in the midst of a gale - how great a diversity of pressure must exist in a large extent of atmosphere. This internal work of the wind will lift the soaring bird at times to higher levels, from which without special movement of the wings it may descend in the very face of the wind's general course.

From the beginning, however, of his experiments Langley had sought to devise a successful flying machine. In 1887 and the following years he constructed about forty rubber-driven models, all of which were submitted to trial and modification. From these tests he felt that he learned much about the conditions of flight in free air which could not be learned from the more definitely controlled tests with simple planes on the whirling table. His essential object was, of course, to reduce the principles of equilibrium to practice. Besides different forms and sizes he tried various materials of construction, and ultimately various means of propulsion. Before he could test his larger steam-driven models, made for the most part of steel and weighing about one thousand times as much as the air displaced, Langley spent many months contriving and constructing suitable launching apparatus. The solution of the problem of safe descent after flight he in a sense postponed, conducting his experiments from a houseboat on the Potomac, where the model might come down without serious damage.

It was on May 6, 1896 (the anniversary of which date is now celebrated as Langley Day), that the success was achieved which all who witnessed it considered decisive of the future of mechanical flight. 


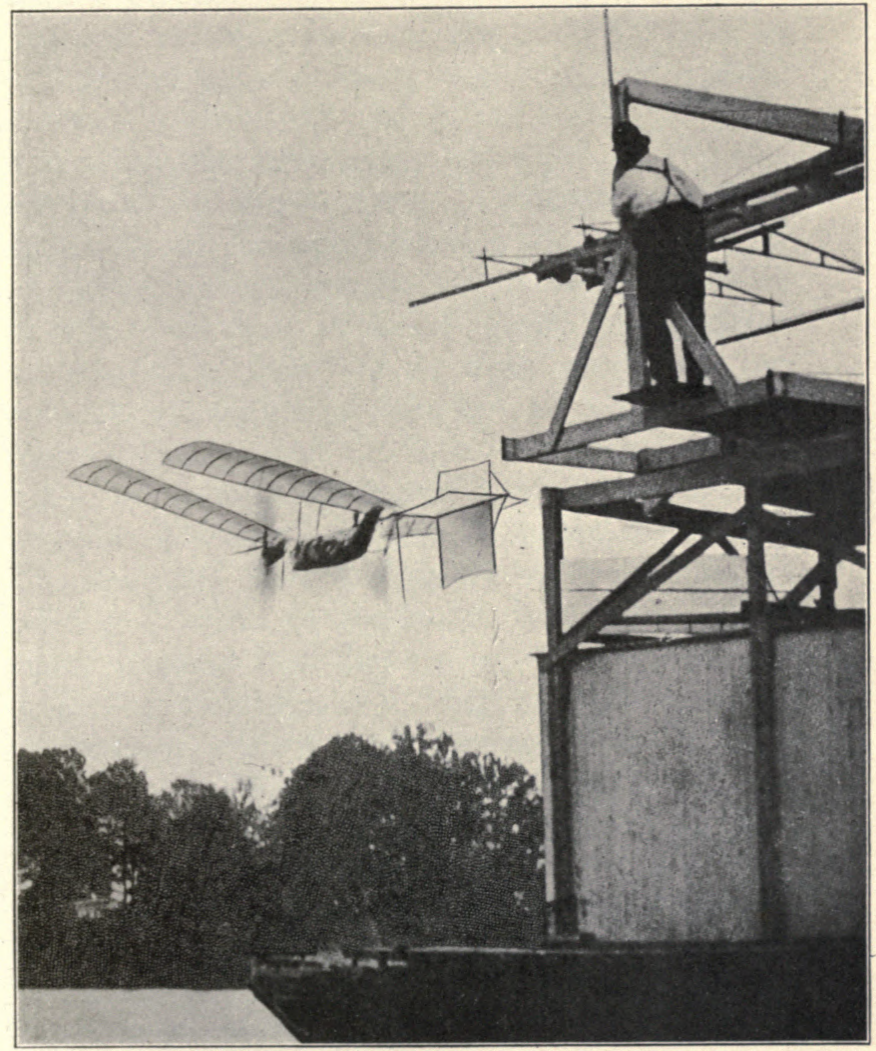

THE FIRST SUCCESSFUL HEAVIER-THAN-AIR FLYING MACHINE A photograph taken at the moment of launching Langley's aerodrome May 6, 1896 

The whole apparatus - steel frame, miniature steam engine, smoke stack, condensed-air chamber, gasoline tank, wooden propellers, wings - weighed about twenty-four pounds. There was developed a steam pressure of about 115 pounds, and the actual power was nearly one horse-power. At a given signal the aeroplane was released from the overhead launching apparatus on the upper deck of the house-boat. It rose steadily to an ultimate height of from seventy to a hundred feet. It circled (owing to the guys of one wing being loose) to the right, completing two circles and beginning a third as it advanced; so that the whole course had the form of a spiral. At the end of one minute and twenty seconds the propellers began to slow down owing to the exhaustion of fuel. The aeroplane descended slowly and gracefully, appearing to settle on the water. It seemed to Alexander Graham Bell that no one could witness this interesting spectacle, of a flying machine in perfect equilibrium, without being convinced that the possibility of aerial flight by mechanical means had been demonstrated. On the very day of the test he wrote to the Académie des Sciences that there had never before been constructed, so far as he knew, a heavierthan-air flying machine, or aerodrome, which could by its own power maintain itself in the air for more than a few seconds.

Langley felt that he had now completed the work in this field which properly belonged to him as a scientist - " the demonstration of the practicability of mechanical flight" - and that the public might look to others for its development and commercial exploitation. Like Franklin and Davy he declined 
to take out patents, or in any way to make money from scientific discovery; and like Henry, the first Secretary of the Smithsonian Institution (to whom the early development of electro-magnetic machines was due), he preferred to be known as a scientist rather than as an inventor.

Nevertheless, Langley's desire to construct a large, man-carrying aeroplane ultimately became irresistible. Just before the outbreak of the Spanish War in $\mathbf{1 8 9 8}$ he felt that such a machine might be of service to his country in the event of hostilities that seemed to him imminent. The attention of President McKinley was called to the matter, and a joint commission of Army and Navy officers was appointed to make investigation of the results of Professor Langley's experiments in aerial navigation. A favorable report having been made by that body, the Board of Ordnance and Fortification recommended a grant of fifty thousand dollars to defray the expenses of further research. Langley was requested to undertake the construction of a machine which might lead to the development of an engine of war, and in December, 1898, he formally agreed to go on with the work.

He hoped at first to obtain from manufacturers a gasoline engine sufficiently light and sufficiently powerful for a man-carrying machine. After several disappointments, the automobile industry being then in its infancy, he succeeded in constructing a fivecylinder gasoline motor of fifty-two horse-power and weighing only about a hundred and twenty pounds. $\mathrm{He}$ also constructed new launching apparatus. After tests with superposed sustaining surfaces, he adhered to the "single-tier plan." There is interesting evi- 
dence that in 1900 Langley renewed his study of the flight of soaring birds, the area of their extended wing surface in relation to weight, and the vertical distance between the center of pressure and the center of gravity in gulls and different species of buzzards. He noted among other things that the tilting of a wing was sufficient to bring about a complete change of direction.

By the summer of 1903 two new machines were ready for field trials, which were undertaken from a large house-boat, especially constructed for the purpose and then moored in the mid-stream of the Potomac about forty miles below Washington. The larger of these two machines weighed seven hundred and five pounds and was designed to carry an engineer to control the motor and direct the flight. The motive power was supplied by the light and powerful gasoline engine already referred to. The smaller aeroplane was a quarter-size model of the larger one. It weighed fifty-eight pounds, had an engine of between two and a half and three horse-power, and a sustaining surface of sixty-six square feet.

This smaller machine was tested August 8, 1903, the same launching apparatus being employed as with the steam-driven models of 1896 . In spite of the fact that one of the mechanies failed to withdraw a certain pin at the moment of launching, and that some breakage of the apparatus consequently occurred, the aeroplane made a good start, and fulfilled the main purpose of the test by maintaining a perfect equilibrium. After moving about three hundred and fifty feet in a straight course it wheeled a quarter-circle to the right, at the same time descending 
slightly, the engine slowing down. Then it began to rise, moving straight ahead again for three or four hundred feet, the propellers picking up their former rate. Once more the engine slackened, but, before the aeroplane reached the water, seemed to regain its normal speed. For a third time the engine slowed down, and, before it recovered, the aeroplane had touched the water. It had traversed a distance of one thousand feet in twenty-seven seconds. One of the workmen confessed that he had poured into the tank too much gasoline. This had caused an overflow into the intake pipe, which in turn interfered with the action of a valve.

The larger aeroplane with the engineer Manly on board was first tested on October 7 of the same year, but the front guy post caught in the launching car and the machine plunged into the water a few feet from the house-boat. In spite of this discouraging mishap the engineers and others present felt confidence in the aeroplane's power to fly. What would to-day be regarded by an aeronaut as a slight setback seemed at that moment like a tragic failure. The fifty thousand dollars had been exhausted nearly two years previously; Professor Langley had made as full use as seemed to him advisable of the resources put at his disposal by the Smithsonian Institution; the young men of the press, for whom the supposed aberration of a great scientist furnished excellent copy, were virulent in their criticisms. Manly made one more heroic attempt under very unfavorable conditions at the close of a winter's day (December 8, 1903). Again difficulty occurred with the launching gear, the rear wings and rudder being wrecked be- 
fore the aeroplane was clear of the ways. The experiments were now definitely abandoned, and the inventor was overwhelmed by the sense of failure, and still more by the skepticism with which the public had regarded his endeavors.

In 1905 an account of Langley's aeroplane appeared in the Bulletin of the Italian Aeronautical Society. Two years later this same publication in an article on a new Blériot aeroplane said: "The Bleriot IV in the form of a bird ... does not appear to give good results, perhaps on account of the lack of stability, and Blériot, instead of trying some new modification which might remedy such a grave fault, laid it aside and at once began the construction of a new type, No. V, adopting purely and simply the arrangement of the American, Langley, which offers a good stability." In the summer of 1907 Bleriot obtained striking results with this machine, the launching problem having been solved in the previous year - the year of Langley's death - by the use of wheels which permitted the aeroplane to get under way by running along the ground under its own driving power. The early flights with No. V were made at a few feet from the ground, and the clever French aviator could affect the direction of the machine by slightly shifting his position, and even had skill to bring it down by simply leaning forward. By the use of the steering apparatus he circled to the right or to the left with the grace of a bird on the wing. When, on July 25, 1909, Bleriot crossed the English Channel in his monoplane, all the world knew that man's conquest of the air was a fait accompli. 
About three years after Langley's death the Board of Regents of the Smithsonian Institution established the Langley Medal for investigations in aerodromics in its application to aviation. The first award went (1909) to Wilbur and Orville Wright, the second (1913) to Mr. Glenn H. Curtiss and M. Gustave Eiffel. On the occasion of the presentation of the medals of the second award-May 6, 1913 - the Langley Memorial Tablet, erected in the main vestibule of the Smithsonian building, was unveiled by the scientist's old friend, Dr. John A. Brashear. In the words of the present Secretary of the Institution, the tablet represents Mr. Langley seated on a terrace where he has a clear view of the heavens, and, in a meditative mood, is observing the flight of birds, while in his mind he sees his aerodrome soaring above them.

The lettering of the tablet is as follows :-

\section{SAMUEL PIERPONT LANGLEY \\ 1834-1906}

SECRETARY OF THE SMITHSONIAN INSTITUTION

1887-1906

DISCOVERED THE RELATIONS OF SPEED AND ANGLE OF INCLINATION TO THE LIFTING POWER OF SURFACES WHEN MOVING IN AIR

"I have brought to a close the portion of the work which seemed to be especially mine, the demonstration of the practicability of mechanical flight."

"The great universal highway overhead is now soon to be opened." - Langley, 1897. 
A still more fitting tribute to the memory of the great inventor came two years later from a successful aviator. In the spring of $1914 \mathrm{Mr}$. Glenn H. Curtiss was invited to send apparatus to Washington for the Langley Day Celebration. He expressed the desire to put the Langley aeroplane itself in the air. The machine was taken to the Curtiss Aviation Field at Kouka Lake, New York. Langley's method of launching had been proved practical, but Curtiss finally decided to start from the water, and accordingly fitted the aeroplane with hydroaeroplane floats. In spite of the great increase in weight involved by this addition, the Langley aeroplane, under its own power plant, skimmed over the wavelets, rose from the lake, and soared gracefully in the air, maintaining its equilibrium, on May 28, 1914, over eight years after the death of its designer. When furnished with an eighty horse-power motor, more suited to its increased weight, the aerodrome planed easily over the water in more prolonged flight. In the periodical publications of June, 1914, may be read the eloquent announcement: "Langley's Folly Flies." 


\section{REFERENCES}

Alexander Graham Bell, Experiments in Mechanical Flight, Nature, May 28, 1896.

Alexander Graham Bell, The Pioneer Aerial Flight, Scientific American, Supplement, Feb. 26, 1910.

S. P. Langley, Experiments in Aerodynamics.

S. P. Langley, The "Flying Machine," McClure's, June, 1897 (illustrated).

Langley Memoir on Mechanical Flight, Smithsonian Contributions to Knowledge, vol. 27, no. 3 (illustrated).

Scientific American, Jan. 13, 1912, A Memorial Honor to a Pioneer Inventor.

The Smithsonian Institution 1846-1896. The History of its First Half-Century, edited by G. B. Goode.

A. F. Zahm, The First Man-carrying Aeroplane capable of Sustained Free Flight, Annual Report of the Smithsonian Institution, 1914 (illustrated). 


\section{CHAPTER XVIII}

\section{SCIENTIFIC HYPOTHESIS - RADIOACTIVE}

\section{SUBSTANCES}

THE untrained mind, reliant on so-called facts and distrustful of mere theory, inclines to think of truth as fixed rather than progressive, static rather than dynamic. It longs for certainty and repose, and has little patience for any authority that does not claim absolute infallibility. Many a man of the world is bewildered to find Newton's disciples building upon or refuting the teachings of the master, or to learn that Darwin's doctrine is itself subject to the universal law of change and development. Though in ethics and religion the older order changes yielding place to new, and the dispensation of an eye for an eye and a tooth for a tooth finds its fulfilment and culmination in a dispensation of forbearance and non-resistance of evil, still many look upon the overthrow of any scientific theory not as a sign of vitality and advance, but as a symptom of the early dissolution or at least of the bankruptcy of science. It is not surprising, therefore, that the public regard the scientific hypothesis with a kind of contempt; for a hypothesis ( $\left(v \pi \theta^{\prime} \theta \epsilon \iota \varsigma\right.$, foundation, supposition) is necessarily ephemeral. When disproved, it is shown to have been a false supposition; when proved, it is no longer hypothetic.

Yet a page from the history of science should indicate that hypotheses play a rôle in experimental 
science and lead to results that no devotee of facts and scorner of mere theory can well ignore.

In 1895 Sir William Ramsay, who in the previous year had discovered an inert gas, argon, in the atmosphere, identified a second inert gas (obtained from minerals containing uranium and thorium) as helium ( $\eta$ ' $\iota$ cos, sun), an element previously revealed by spectrum analysis as a constituent of the sun. In the same year Röntgen, while experimenting with the rays that stream from the cathode in a vacuum tube, discovered new rays (which he called X-rays) possessed of wonderful photographic power. At the beginning of 1896 Henri Becquerel, experimenting on the supposition, or hypothesis, that the emission of rays was associated with phosphorescence, tested the photographic effects of a number of phosphorescent substances. He exposed; among other compounds, crystals of the double sulphate of uranium and potassium to sunlight and then placed upon the crystals a photographic plate wrapped in two thicknesses of heavy black paper. The outline of the phosphorescent substance was developed on the plate. An image of a coin was obtained by placing it between uranic salts and a photographic plate. Two or three days after reporting this result Becquerel chanced (the sunlight at the time seeming to him too intermittent for experimentation) to put away in the same drawer, and in juxtaposition, a photographic plate and these phosphorescent salts. To his surprise he obtained a clear image when the plate was developed. He now assumed the existence of invisible rays similar to X-rays. They proved capable of passing through sheets of aluminum and of copper, and of discharging electri- 
fied bodies. Days elapsed without any apparent diminution of the radiation. On the supposition that the rays might resemble light he tried to refract, reflect, and polarize them; but this hypothesis was by the experiments of Rutherford, and of Becquerel himself, ultimately overthrown. In the mean time the French scientist obtained radiations from metallic uranium and from uranous salts. These, in contrast with the uranic salts, are non-phosphorescent. Becquerel's original hypothesis was thus overthrown. Radiation is a property inherent in uranium and independent both of light and of phosphorescence.

On April 13 and April 23 (1898) respectively Mme. Sklodowska Curie and G. C. Schmidt published the results of their studies of the radiations of the salts of thorium. Each of these studies was based on the work of Becquerel. Mme. Curie examined at the same time the salts of uranium and a number of uranium ores. Among the latter she made use of the composite mineral pitchblende from the mines of Joachimsthal and elsewhere, and found that the radiations from the natural ores are more active than those from pure uranium. This discovery naturally led to further investigation, on the assumption that pitchblende contains more than one radioactive substance. Polonium, named by Mme. Curie in honor of her native country, was the third radioactive element to be discovered. In the chemical analysis of pitchblende made by Mme. Curie (assisted by M. Curie) polonium was found associated with bismuth. Radium, also discovered in this analysis of 1898 , was associated with barium. Mme. Curie succeeded in obtaining the pure chloride of 
radium and in determining the atomic weight of the new element. There is (according to Soddy) about one part of radium in five million parts of the best pitchblende, but the new element is about one million times more radioactive than uranium. It was calculated by M. Curie that the energy of one gram of radium would suffice to lift a weight of five hun-. dred tons to a height of one mile. After discussing the bearing of the discovery of radioactivity on the threatened exhaustion of the coal supply Soddy writes enthusiastically: "But the recognition of the boundless and inexhaustible energy of Nature (and the intellectual gratification it affords) brightens the whole outlook of the twentieth century." The element yields spontaneously radium emanation without any apparent diminution of its own mass. In 1899 Debierne discovered, also in the highly complex pitchblende, actinium, which has proved considerably less radioactive than radium. During these investigations M. and Mme. Curie, M. Becquerel, and those associated with them were influenced by the hypothesis that radioactivity is an atomic property of radioactive substances. This hypothesis came to definite expression in 1899 and again in 1902 through Mme. Curie.

In the latter year the physicist E. Rutherford and the chemist F. Soddy, while investigating the radioactivity of thorium in the laboratories of McGill University, Montreal, were forced to recognize that thorium continuously gives rise to new kinds of radioactive matter differing from itself in chemical properties, in stability, and in radiant energy. They concurred in the view held by all the most prominent 
workers in this subject, namely, that radioactivity is an atomic phenomenon. It is not molecular decomposition. They declared that the radioactive substances must be undergoing a spontaneous transformation. The daring nature of this hypothesis and its likelihood to revolutionize physical science is brought home to one by recalling that three decades previously an eminent physicist had said that "though in the course of ages catastrophes have occurred and may yet occur in the heavens, though ancient systems may be dissolved and new systems evolved out of their ruins, the molecules [atoms] out of which these systems are built - the foundation stones of the material universe - remain unbroken and unworn."

In 1903 Rutherford and Soddy stated definitely their hypothesis, generally known as the "Transformation Theory," that the atoms of radioactive substances suffer spontaneous disintegration, a process unaffected by great changes of temperature (or by physical or chemical changes of any kind at the disposal of the experimenter) and giving rise to new radioactive substances differing in chemical (and physical) properties from the parent elements. The radiations consist of $a$ particles (atoms of helium minus two negative electrons), $\beta$ particles, or electrons (charges of negative electricity), and $\gamma$ rays, of the nature of Röntgen rays and light but of very much shorter wave length and of very great penetrating power. It is by the energy inherent in the atom of the radioactive substance that the radiations are ejected, sometimes, in the case of the $\gamma$ rays with velocity sufficient to penetrate two feet of lead. It is through these radiations that spontaneous transformation 


\section{THE HISTORY OF SCIENCE}

takes place. After ten years of further investigation Rutherford stated that this hypothesis affords a satisfactory explanation of all radioactive phenomena, and gives unity to what without it would seem disconnected facts. Besides accounting for old experimental results it suggests new lines of work and even enables one to predict the outcome of further investigation. It does not really contradict, as some thought might be the case, the principle of the conservation of energy. The atom, to be sure, can no longer be considered the smallest unit of matter, as the mass of a $\beta$ particle is approximately one seventeen-hundredths that of an atom of hydrogen. Still the new hypothesis is a modification and not a contradiction of the atomic theory.

The assumption that the series of radioactive substances is due, not to such molecular changes as chemistry had made familiar, but to a breakdown of the atom seemed to Rutherford in 1913 at least justified by the results of the investigators whose procedure had been dictated by that hypothesis. He set forth in tables these results (since somewhat modified), indicating after the name of each radioactive substance the nature of the radiation through the emission of which the element is transformed into the next-succeeding member of its series.

List of Radioactive Substances

$\begin{array}{ll}\text { URANIUM } & a \text { particles } \\ \text { Uranium X } & \beta+\gamma \\ \text { Uranium Y } & \beta \\ \text { IONIUM } & \alpha\end{array}$




\section{SCIENTIFIC HYPOTHESIS}

RADIUM

Emanation

Radium A

Radium B

Radium C $\left\{\begin{array}{l}\mathrm{C}_{1} \\ \mathrm{C}_{2}\end{array}\right.$

RADIUM D

RADIO-LEAD

Radium E

Radium F

Polonium $\alpha+$ slow $\beta$

$\alpha$

$\alpha$

$\beta+\gamma$

$\alpha+\beta+\gamma$

$\beta$

\} slow $\beta$

$\beta+\gamma$

\}$a$

THORIUM

$\boldsymbol{a}$

MESOTHORIUM 1 no rays

Mesothorium 2

RADIOTHORIUM $a$

Thorium $\mathrm{X}$

Emanation

$\beta+\gamma$

Thorium A

$\alpha+\beta$

$\boldsymbol{a}$

Thorium B

Thorium $C\left\{\begin{array}{l}C^{1} \\ C_{2}\end{array}\right.$

Thorium D

$\alpha$

slow $\beta$

a

$a$

$\beta+\gamma$

ACTINIUM

Radio-actinium

Actinium X

Emanation

Actinium A

Actinium B

Actinium C

Actinium D

no rays

$\alpha+\beta$

$\boldsymbol{a}$

$\boldsymbol{a}$

a

slow $\beta$

a

$a+\gamma$ 
Even a glance at this long list of new elements reveals certain analogies between one series of transformations and another. Each series contains an emanation, or gas, which through the loss of $a$ particles is transformed into the next following member of the series. Continuing the comparison in either direction, up or down the lists, one could readily detect other analogies.

There is some ground for thinking that lead is the end product of the Uranium series. To reverse the process of the transformation and produce radium from the base metal lead would be an achievement greater than the vaunted transmutations of the alchemists. Although that seems beyond the reach of possibility, the idea has stirred the imagination of more than one scientist. "The philosopher's stone," writes Soddy, "was accredited the power not only of transmuting the metals, but of acting as the elixir of life. Now, whatever the origin of this apparently meaningless jumble of ideas may have been, it is really a perfect and but very slightly allegorical expression of the actual present views we hold to-day." Again, it is conjectured that bismuth is the end-product of the thorium series. The presence of the results of atomic disintegration (like lead and helium) has proved of interest to geology and other sciences as affording a clue to the age of the rocks in which they are found deposited.

Before Rutherford, Mme. Curie, and others especially interested in radioactive substances, assumed that atoms are far different from the massy, hard, impenetrable particles that Newton took for granted, Sir J. J. Thomson and his school were studying the 
constitution of the atom from another standpoint but with somewhat similar results. This great physicist had proved that cathode rays are composed not of negatively charged molecules, as had been supposed, but of much smaller particles or corpuscles. Wherever, as in the vacuum tube, these electrons appear, the presence of positively charged particles can also be demonstrated. It is manifest that the atom, instead of being the ultimate unit of matter, is a system of positively and negatively chasged particles. Rutherford in the main concurred in this view, though differing from Sir J. J. Thomson as to the arrangement of corpuscles within the atom. Let it suffice here to state that Rutherford assumes that the greater mass of the atom consists of negatively charged particles rotating about a positive nucleus. The surrounding electrons render the atom electrically neutral.

This corpuscular theory of matter may throw light on the laws of chemical combination. The so-called chemical affinity between two atoms of such and such valencies, which Davy and others since his time had regarded as essentially an electrical phenomenon, seems now to admit of more definite interpretation. Each atom is negatively or positively charged according to the addition or subtraction of electrons. Chemical composition takes place between atoms the charges of which are of opposite sign, and valency depends on the number of unit charges of electricity. Moreover, the electrical theory of matter lends support to the hypothesis that there is a fundamental unitary element underlying all the so-called elements. The fact that elements fall into groups and that their chemical properties vary with their atomic weights long ago sug- 
gested this assumption of a primitive matter, protyl, from which all other substances were derived. In the light of the corpuscular theory as well as of the transformation theory it seems possible that the helium atom and the negative corpuscle will offer a clue to the genesis of the elements.

What is to be learned from this rapid sketch, of the discovery of the radioactive substances, concerning the nature and value of scientific hypothesis? For one thing, the scientific hypothesis is necessary to the experimenter. The mind runs ahead of and guides the experiment. Again, the hypothesis suggests new lines of research, enables one in some cases to anticipate the outcome of experiment, and may be abundantly justified by results. "It is safe to say," writes Rutherford, "that the rapidity of growth of accurate knowledge of radioactive phenomena has been largely due to the influence of the disintegration theory." The valid hypothesis serves to explain facts, leads to discovery, and does not conflict with known facts or with verified generalizations, though, as we have seen, it may modify other hypotheses. Those who support a hypothesis should bring it to the test of rigid verification, avoiding skepticism, shunning credulity. \{Even a false assumption, as we have seen, may prove valuable when carefully put to the proof.

The layman's distrust of the unverified hypothesis is in the main wholesome. It is a duty not to believe it, not to disbelieve it, but to weigh judicially the evidence for and against. The fact that assumption plays a large part in our mental attitude toward practical affairs should make us wary of contesting the legitimacy of scientific hypotheses. 
No one would deny the right of forming a provisional assumption to the intelligence officer interpreting a cipher, or to the detective unravelling the mystery of a crime. The first assumes that the message is in a certain language, and, perhaps, that each symbol employed is the equivalent of a letter, his assumption is put to the proof of getting a reasonable and consistent meaning from the cipher. The detective assumes a motive for the crime, or the employment of certain means of escape; even if his assumption does not clear up the mystery, it may have value as leading to a new and more adequate assumption.

Henri Poincare has pointed out that one of the most dangerous forms of hypothesis is the unconscious hypothesis. It is difficult to prove or disprove because it does not come to clear statement. The alleged devotee of facts and of things as they are, in opposing the assumptions of an up-to-date science, is often, unknown to himself, standing on a platform of outworn theory, or of mere vulgar assumption. For example, when Napoleon was trying to destroy the commercial wealth of England at the beginning of the nineteenth century, he unconsciously based his procedure on an antiquated doctrine of political economy. For him the teachings of Adam Smith and Turgot were idle sophistries. "I seek," he said to his Minister of Finance, "the good that is practical, not the ideal best : the world is very old; we must profit by its experience; it teaches that old practices are worth more than new theories : you are not the only one who knows trade secrets." We are not here especially concerned with the question of whether Napoleon was or was not pursuing the best 
means of breaking down English credit. He did try to prevent the English from exchanging exports for European gold, while permitting imports in the hope of depleting England of gold. But in pursuing this policy he thought he was proceeding on the ground of immemorial practice, while he was merely pitting the seventeenth-century doctrine of Locke against the doctrine of Adam Smith which had superseded it.

According to one scientific hypothesis, "Species originated by means of natural selection, or, through the preservation of favored races in the struggle for life." This assumption was rightly subjected to close scrutiny in 1859 and the years following. The ephemeral nature of the vast majority of hypotheses and the danger to progress of accepting an unverified assumption justify the demand for demonstrative evidence. The testimony having been examined, it is our privilege to state and to support the opposing hypothesis. It was thus that the hypothesis that the planets move in circular orbits, recommended by its simplicity and rsthetic quality, was forced to give way to the hypothesis of elliptical orbits. Newton's hypothesis that light is due to particles emitted by . all luminous bodies yielded, at least for the time, to the theory of light vibrations in an ether pervading all space. The path of scientific progress is strewn. with the ruins of overthrown hypotheses. Many of the defeated assumptions have been merely implicit errors of the man in the street, and they are overthrown not by facts alone, but by new hypotheses verified by facts and leading to fresh discoveries.

According to John Stuart Mill, "It appears ... to be a condition of a genuinely scientific hypothesis, 
that it be not destined always to remain an hypothesis, but be of such a nature as to be either proved or disproved by that comparison with observed facts which is termed Verification." This statement is of value in confirming the general distrust of mere hypothesis, and in distinguishing between the unverified and unverifiable presupposition and the legitimate assumption which through verification may become established doctrine.

\section{REFERENCES}

J. Cox, Beyond the Atom, 1913 (Cambridge Manuals of Science and Literature).

R. K. Duncan, The New Knowledge, 1905.

H. Poincaré, Science and Hypothesis.

E. Rutherford, Radioactive Substances and their Radiations.

F. Soddy, The Interpretation of Radium.

F. Soddy, Matter and Energy (Home University Library).

Sir William A. Tilden, Progress of Scientific Chemistry in our Own Time, 1913. 


\section{CHAPTER XIX}

\section{THE SCIENTIFIC IMAGINATION}

Psychology, or the science of mental life as revealed in behavior, has been greatly indebted to physiologists and to students of medicine in general. Any attempt to catalogue the names of those who have approached the study of the mind from the direction of the natural sciences is liable to prove unsatisfactory, and a brief list is sure to entail many important omissions. The mention of Locke, Cheselden, Hartley, Cabanis, Young, Weber, Gall, Müller, Du Bois-Reymond, Bell, Magendie, Helmholtz, Darwin, Lotze, Ferrier, Goltz, Munk, Mosso, Maudsley, Carpenter, Galton, Hering, Clouston, James, Janet, Kraepelin, Flechsig, and W undt will, however, serve to remind us of the richness of the contribution of the natural sciences to the so-called mental science. Indeed, physiology would be incomplete unless it took account of the functions of the sense organs, of the sensory and motor nerves, of the brain with its association areas, as well as the expression of the emotions, and the changes of function accompanying the development of the nervous system, from the formation of the embryo till physical dissolution, and from" species of the simplest to those of the most complex organization.

At the beginning of the nineteenth century the French physician Cabanis was disposed to identify human personality with mere nervous organization 
reacting to physical impressions, and to look upon the brain as the organ for the production of mind. He soon, however, withdrew from this extreme position and expressed his conviction of the existence of an immortal spirit apart from the body. One might say that the brain is the instrument through which the mind manifests itself rather than the organ by which mind is excreted. Even so, it must be agreed that the relation between the psychic agent and the physical instrument is so close that physiology must take heed of mental phenomena and that psychology must not ignore the physical concomitants of mental processes. Hence arises a new branch of natural science, physiological psychology, or, as Fechner (1860), the disciple of Weber, called it, psychophysics.

Through this alliance between the study of the mind and the study of bodily functions the intelligence of the lower animals and its survival value, the mental growth of the child, mental deterioration in age and disease, and the psychological endowments of special classes or of individuals, became subjects for investigation. Now human psychology is recognized as contributing to various branches of anthropology, or the general study of man.

Wilhelm Wundt, who, as already implied, had approached the study of the mind from the side of the natural sciences, established in 1875 at the University of Leipzig the first psycho-physical institute for the experimental study of mental phenomena. His express purpose was to analyze the content of consciousness into its elements, to examine these elements in their qualitative and quantitative differences, and to deter- 
mine with precision the conditions of their existence and succession. Thus science after contemplating a wide range of outer phenomena - plants, animals, earth's crust, heavenly bodies, molecules and atoms - turns its attention with keen scrutiny inward on the thinking mind, the subjective process by which man becomes cognizant of all objective things.

The need of expert study of the human mind as the instrument of scientific discovery might have been inferred from the fact that the physicist Tyndall read before the British Association in 1870 a paper on the Scientific Use of the Imagination, in which he spoke of the imagination as the architect of physical theory, cited Newton, Dalton, Davy, and Faraday as affording examples of the just use of this creative power of the mind, and quoted a distinguished chemist as identifying the mental process of scientific discovery with that of artistic production. Tyndall even chased the psychologists in their own field and stated that it was only by the exercise of the imagination that we could ascribe the possession of mental powers to our fellow creatures. "You believe that in society you are surrounded by reasonable beings like yourself. ... What is your warrant for this conviction? Simply and solely this: your fellow-creatures behave as if they were reasonable."

On the traces of this brilliant incursion of the natural philosopher into the realm of mental science, later psychologists must follow but haltingly. Just as in the history of physies a long series of studies intervened between Bacon's hypothesis that heat is a kind of motion (1620) and Tyndall's own work, Heat as a Mode of Motion (1863), so must many 


\section{THE SCIENTIFIC IMAGINATION 261}

psychological investigations be made before an adequate psychology of scientific discovery can be formulated. It may ultimately prove that the passages in which Tyndall and other scientists speak of scientific imagination would read as well if for this term, intuition, inspiration, unconscious cerebration, or even reason were substituted.

At first glance it would seem that the study of the sensory elements of consciousness, motor, tactile, visual, auditory, olfactory, gustatory, thermal, internal, pursued for the last half century by the experimental method, would furnish a clue to the nature of the imagination. A visual image, or mental picture, is popularly taken as characteristic of the imaginative process. In fact, the distinguished psychologist William James devotes the whole of his interesting chapter on the imagination to the discussion of different types of imagery. The sensory elements of consciousness are involved, however, in perception, memory, volition, reason, and sentiment, as they are in imagination. They have been recognized as fundamental from antiquity. Nothing is in the intellect which was not previously in the senses. To be out of one's senses is to lack the purposive guidance of the intelligence.

The psychology of individuals and groups shows startling differences in the kind and vividness of imagery. Many cases are on record where the mental life is almost exclusively in visual, in auditory, or in motor terms. One student learns a foreign language by writing out every word and sentence; another is wholly dependent on hearing them spoken; a third can recall the printed page with an almost photo- 
graphic vividness. The history of literature and art furnishes us with illustrations of remarkable powers of visualization. Blake and Fromentin were able to reproduce in pictures scenes long retained in memory. The latter recognized that his painting was not an exact reproduction of what he had seen, but that it was none the less artistic because of the selective influence that his mind had exerted on the memory image. Wordsworth at times postponed the description of a scene that appealed to his poetic fancy with the express purpose of blurring the outlines, but enhancing the personal factor. Goethe had the power to call up at will the form of a flower, to make it change from one color to another and to unfold before his mind's eye. Professor Dilthey has collected many other records of the hallucinatory clearness of the visual imagery of literary artists.

On the other hand, Galton, after his classical study of mental imagery (1883), stated that scientific men, as a class, have feeble powers of visual representation. He had appealed for evidence of visual recall to distinguished scientists because he thought them more capable than others of accurately stating the results of their introspection. He had recourse not only to English but to foreign scientists, including members of the French Institute. "To my astonishment," he writes, "I found that the great majority of men of science to whom I first applied protested that mental imagery was unknown to them, and they looked on me as fanciful and fantastic in supposing that the words 'mental imagery' really expressed what I believed everybody supposed them to mean. They had no more notion of its true nature than a 


\section{THE SCIENTIFIC IMAGINATION 263}

color-blind man, who has not discerned his defect, has of the nature of color." One scientist confessed that it was only by a figure of speech that he could describe his recollection of a scene as a mental image to be perceived with the mind's eye.

When Galton questioned persons whom he met in general society he found " an entirely different disposition to prevail. Many men and a yet larger number of women, and many boys and girls, declared that they habitually saw mental imagery, and that it was perfectly distinct to them and full of color." The evidence of this difference between the psychology of the average distinguished scientist and the average member of general society was greatly strengthened upon cross-examination. Galton attributed the difference to the scientist's " habits of highly generalized and abstract thought, especially when the steps of reasoning are carried on by words [employed] as symbols."

It is only by the use of words as symbols that scientific thought is possible. It is through coöperation in work that mankind has imposed its will upon the creation, and coöperation could not have been carried far without the development of language as a means of communication. Were it not for the help of words we should be dependent, like the lower animals, on the fleeting images of things. We should be bound to the world of sense and not have range in the world of ideas. Words are a free medium for thought, for the very reason that they are capable of shifting their meaning and taking on greater extension or intension. For example, we may say that the apple falls because it is heavy, or we may substitute synonymous 
phraseology that helps us to view the falling apple in its universal aspects. The mind acquires through language a field of activity independent of the objective world. We have seen in an earlier chapter that geometry developed as a science is becoming gradually weaned from the art of surveying. Triangles and rectangles cease to suggest meadows, or vineyards, or any definite imagery of that sort, and are discussed in their abstract relationship. Science demands the conceptual rather than the merely sensory. The invisible real world of atoms and corpuscles has its beginning in the reason, the word. To formulate new truths in the world of ideas is the prerogative of minds gifted with exceptional reason.

To be sure, language itself may be regarded as imagery. Some persons visualize every word spoken as though it were seen on the printed page ; others cannot recall a literary passage without motor imagery of the speech organs or even incipient speech; while others again experience motor imagery of the writing hand. With many, in all forms of word-consciousness, the auditory image is predominant. In the sense of being accompanied by imagery all thinking is imaginative. But it is the use of words that permits us to escape most completely from the more primitive forms of intelligence. So directly does the printed word convey its meaning to the trained mind that to regard it as so much black on white rather than as a symbol is a rare and rather upsetting mental experience. Words differ among themselves in their power to suggest images of the thing symbolized. The word "existence" is less imageproducing than "flower," and "flower" than "red 


\section{THE SCIENTIFIC IMAGINATION 265}

rose." It is characteristic of the language of science to substitute the abstract or general expression for the concrete and picturesque.

When, therefore, we are told that the imagination has been at the bottom of all great scientific discoveries, that the discovery of law is the peculiar function of the creative imagination, and that all great scientists have, in a certain sense, been great artists, we are confronted with a paradox. In what department of thought is imagination more strictly subordinated than in science? Genetic psychology attempts to trace the development of mind as a means of adjustment. It examines the instincts that serve so wonderfully the survival of various species of insects. It studies the more easily modified instinct of birds, and notes their ability to make intelligent choice on the basis of experience. Does the bird's ability to recognize imply the possession of memory, or imagery? Increased intelligence assures perpetuation of other species in novel and unforeseen conditions. The more tenacious the memory, the richer the supply of images, the greater the powers of adaptation and survival. We know something concerning the motor memory of rodents and horses, and its biological value. The child inherits less definitely organized instincts, but greater plasticity, than the lower animals. Its mental life is a chaos of images. It is the work of education to discipline as well as to nourish the senses, to teach form as well as color, to impart the clarifying sense of number, weight, and measurement, to help distinguish between the dream and the reality, to teach language, the treasure-house of our traditional wisdom, and logic, so closely related to the right use of 
language. The facts of abnormal, as well as those of animal and child psychology, prove that the subordination of the imagination and fancy to reason and understanding is an essential factor in intellectual development.

No one, of course, will claim that the mental activity of the scientific discoverer is wholly unlike that of any other class of man; but it leads only to confusion to seek to identify processes so unlike as scientific generalization and artistic production. The artist's purpose is the conveyance of a mood. The author of Macbeth employs every device to impart to the auditor the sense of blood-guiltiness; every lurid scene, every somber phrase, serves to enhance the sentiment. A certain picture by Dürer, a certain poem of Browning's, convey in every detail the feeling of dauntless resolution. Again, a landscape painter, recognizing that his satisfaction in a certain scene depends upon a stretch of blue water with a yellow strand and old-gold foliage, proceeds to rearrange nature for the benefit of the mood he desires to enliven and perpetuate. It is surely a far cry from the attitude of these artists manipulating impressions in order to impart to others an individual mood, to that of the scientific discoverer formulating a law valid for all intellects.

In the psychology of the present day there is much that is reminiscent of the biological psychology of Aristotle. From the primitive or nutrient soul which has to do with the vital functions of growth and reproduction, is developed the sentient soul, concerned with movement and sensibility. Finally emerges the intellectual and reasoning soul. These three parts 


\section{THE SCIENTIFIC IMAGINATION 267}

are not mutually exclusive, but the lower foreshadow the higher and are subsumed in it. Aristotle, however, interpreted the lower by the higher and not vice versa. It is no compliment to the scientific discoverer to say that his loftiest intellectual achievement is closely akin to fiction, or is the result of a mere brooding on facts, or is accompanied by emotional excitement, or is the work of blind instinct.

It will be found that scientific discovery, while predominantly an intellectual process, varies with the nature of the phenomena of the different sciences and the individual mental differences of the discoverers. As stated at the outset the psychology of scientific discovery must be the subject of prolonged investigation, but some data are already available. One great mathematician, Poincaré, attributes his discoveries to intuition. The essential idea comes with a sense of illumination. It is characterized by suddenness, conciseness, and immediate certainty. It may come unheralded, as he is crossing the street, walking on the cliffs, or stepping into a carriage. There may have intervened a considerable period of time free from conscious effort on the special question involved in the discovery. Poincare is inclined to account for these sudden solutions of theoretical difficulties on the assumption of long periods of previous unconscious work.

There are many such records from men of genius. At the moment the inventor obtains the solution of his problem his mind may seem to be least engaged with it. The long-sought-for idea comes like an inspiration, something freely imparted rather than voluntarily aequired. No mental process is more 
worthy to command respect; but it may not lie beyond the possibility of explanation. Like ethical insight, or spiritual illumination, the scientific idea comes to those who have striven for it. The door may open after we have ceased to knock, or the response come when we have forgotten that we sent in a call; but the discovery comes only after conscious work. The whole history of science shows that it is to the worker that the inspiration comes, and that new ideas develop from old ideas.

It may detract still further from the mysteriousness of the discovery-process to add that the illuminating idea may come in the midst of conscious work, and that then also it may appear as a sudden gift rather than the legitimate outcome of mental effort. The spontaneity of wit may afford another clue to the mystery of scientific discovery. The utterer of a witticism is frequently as much surprised by it as the auditors, probably because the idea comes as verbal imagery, and the full realization of their significance is grasped only with the actual utterance of the words. The fact that to the scientific discoverer the solution of his problem arrives at the moment when it is least sought is analogous to the common experience that the effort to recall a name may inhibit the natural association.

The tendency to emphasize unduly the rôle played by the scientific imagination springs probably from the misconception that the imagination is a psychological superfluity, one of the luxuries of the mental life, which should not be withheld from those who deserve the best. The view lingers with regard to the æsthetic imagination. James could not understand the biologi- 


\section{THE SCIENTIFIC IMAGINATION 269}

cal function of the æsthetic faculty. On the alleged uselessness of this phase of the human mind A.J.Balfour has recently based an argument for the immortality of the soul. This view is strikingly at variance with that which inclines to identify it with that mental process which creates scientific theories and thus paves the way for the adjustment of posterity to earthly conditions.

\section{REFERENCES}

Baldwin, J. M., History of Psychology, 1913. \& vols.

Dessoir, Max, Outlines of the History of Psychology, 1912.

Klemm, Otto, A History of Psychology, 1914.

Merz, J. T., History of European Thought in the Nineteenth Century, vol. II, chap. xII, On the Psycho-physical View of Nature.

Rand, Benjamin, The Classical Psychologists, 1912.

Ribot, T. A., English Psychology, 1889.

Ribot, T. A., German Psychology of To-day, 1886. 


\section{CHAPTER XX}

\section{SCIENCE AND DEMOCRATIC CULTURE}

Education is the oversight and guidance of the development of the immature with certain ethical and social ends in view. Pedagogy, therefore, is based partly on psychology - which, as we have seen in the preceding chapter, is closely related to the biological sciences - and partly on ethics, or the study of morals, closely related to the social sciences. These two aspects of education, the psychological and the sociological, were treated respectively in Rousseau's Emile and Plato's Republic. The former ill-understood work, definitely referring its readers to the latter for the social aspect of education, applies itself as exclusively as possible to the study of the physical and mental development of the individual child. Rousseau consciously set aside the problem of nationality or citizenship; he. was cosmopolitan, and explicitly renounced the idea of planning the education of a Frenchman or a Swiss. Neither did he desire to set forth the education of a wild man, free and unrestrained. He wished rather to depict the development of a natural man in a state of society; but he emphasized the native hereditary endowment, while expressing his admiration for Plato's Republic as the great classic of social pedagogy. The titles of the two works, one from the name of an individual child, the other from a form of government, should serve to remind us of the purpose and limitations of each. 
Plato's thought was centered on the educational and moral needs of the city-state of Athens. He was apprehensive that the city was becoming corrupted through the wantonness and lack of principle of the Athenian youth. He strove to rebuild on reasoned foundations the sense of social obligation and responsibility which had in the earlier days of Athens rested upon faith in the existence of the gods. As a conservative he hoped to restore the ancient Athenian feeling for duty and moral worth, and he even envied some of the educational practices of the rival city-state Sparta, by which the citizen was subordinated to the state. The novel feature of Plato's pedagogy was the plan to educate the directing classes, men disciplined in his own philosophical and ethical conceptions. He was, in fact, an intellectual aristocrat, and spoke of democracy in very ironical terms, as the following sentences will show:

"And thus democracy comes into being after the poor have conquered their opponents. . . . And now what is their manner of life, and what sort of a government have they? For as the government is, such will be the man.... In the first place, are they not free? and the city is full of freedom and frankness - a man may do as he likes. ... And where freedom is, the individual is clearly able to order his own life as he pleases?... Then in this kind of State there will be the greatest variety of human natures? . . . This then will be the fairest of States, and will appear the fairest, being spangled with the manners and characters of mankind, like an embroidered robe which is spangled with every sort of flower. And just as women and children think 
variety charming, so there are many men who will deem this to be the fairest of States. .... And is not the equanimity of the condemned often charming? Under such a government there are men who, when they have been sentenced to death or exile, stay where they are and walk about the world; the gentleman [convict] parades like a hero, as though nobody saw or cared.... See too ... the forgiving spirit of democracy and the 'don't care' about trifles, and the disregard of all the fine principles which we solemnly affirmed ... how grandly does she trample our words under her feet, never giving a thought to the pursuits which make a statesman, and promoting to honor anyone who professes to be the people's friend. ... These and other kindred characteristics are proper to democracy, which is a charming form of government, full of variety and disorder, and dispensing equality to equals and unequals alike. ... Consider now ... what manner of man the individual is ... he lives through the day indulging the appetite of the hour; and sometimes he is lapped in drink and strains of the flute; then he is for total abstinence, and tries to get thin; then, again, he is at gymnastics; sometimes idling and neglecting everything, then once more living the life of a philosopher; often he is in politics, and starts to his feet and says and does whatever comes into his head; and, if he is emulous of anyone who is a warrior, off he is in that direction, or of men of business, once more in that. His life has neither order nor law; so he goes on continually, and he terms this joy and freedom and happiness. Yes, his life is all liberty and equality. Yes, ... and multi- 
form, and full of the most various characters ; . . . he answers to the State, which we described as fair and spangled. . . L Let him then be set over against democracy; he may truly be called the democratic man."

In spite of the satirical tone of this passage much of it may be accepted as the unwilling tribute of a hostile critic. Democracy is the triumph of the masses over the oligarchs. It is merciful in the administration of justice. It shows a magnanimous spirit and does not magnify the importance of trifles. It prefers the rule of its friends to the rule of a despot. Under its government people feel themselves blessed by happiness, liberty, and equality. The culture of the democratic man is above all characterized by adaptability.

In the nineteenth century Matthew Arnold, the apostle of culture, discussing the civilization of a democratic nation of many millions, unconsciously confirmed the views of Plato in some respects, while showing interesting points of difference. He expressed his admiration of the institutions, solid social conditions, freedom and equality, power, energy, and wealth of the people of the United States. In the daintiness of American house-architecture, and in the natural manners of the free and happy American women he saw a real note of civilization. He felt that his own country had a good deal to learn from America, though he did not close his eyes to the real dangers to which all democratic nations are exposed. Arnold failed in his analysis of American civilization to confirm Plato's judgment concerning the variety of natures to be found in the democratic 
State, as well as the Greek philosopher's censure that democracy shows disregard of ethical principles. In fact, Arnold considered the people of the United States singularly homogeneous, singularly free from the distinctions of class; "we [the English] are so little homogeneous, we are living with a system of classes so intense, that the whole action of our minds is hampered and falsened by it; we are in consequence wanting in lucidity, we do not see clear or think straight, and the Americans have here much the advantage of us." As for the second point of difference between Arnold and Plato, the English critic recognized that the American people belonged to the great class in society in which the sense of conduct and regard for ethical principles are particularly developed.

Nearly all the old charges against American democracy can be summarized in one general censure, the lack of calm and reasoned self-criticism, - and this general defect is rapidly being made good. It is partly owing to charity and good-will, and it includes the toleration of the mediocre or inferior, as, for example, in the theater; the failure to recognize distinction, and to pay deference to things deserving it; the glorification of the average man, and the hustler, and the lack of special educational opportunities for the exceptionally gifted child. That criticism as an art is still somewhat behindhand in America seems to be confirmed by comparing French and American literary criticism. In France it is a profession practiced by a corps of experts; in America only a very few of the best periodicals can be relied on to give reviews based on critical principles, of works in verse 
or prose. (One American reviewer confesses that in a single day he has written notices of twenty new works of fiction, his work bringing him, as renuneration, seventy-five cents a volume.)

There is no evidence, however, that Americans as individuals are wanting in the self-critical spirit. And for Arnold this is vital, seeing that the watchword of the culture he proclaims is Know Thyself. It is not a question of gaining a social advantage by a smattering of foreign languages. It is more than intellectual curiosity. "Culture is more properly described as having its origin in the love of perfection. It moves by the force, not merely or primarily of the scientific passion for pure knowledge, but also of the passion for doing good." Human perfection, the essence of culture, is an internal condition, but the will to do good must be guided by the knowledge of what is good to do; "acting and instituting are of little use unless we know how and what we ought to act and institute." Moreover, "because men are all members of one great whole, and the sympathy which is human nature will not allow one member to be indifferent to the rest, the expansion of our humanity, to suit the idea of perfection which culture forms, must be a general expansion."

For Arnold's contemporary Nietzsche, the German exponent of Aristocracy, the expansion of education entailed its diminution. For him ancient Greece was the only home of culture, and such culture was not for all comers. The rights of genius are not to be democratized; not the education of the masses, but rather the education of a few picked men must be the aim. The one purpose which education should 
most zealously strive to achieve is the suppression of all ridiculous claims to independent judgment, and the inculcation upon young men of obedience to the scepter of genius. The scientific man and the cultured man belong to two different spheres which, though coming together at times in the same individual, are never fully reconciled.

In order to appreciate the full perverseness, from the democratic standpoint, of Nietzsche's view of culture, it is necessary to glance at his political ideals as explained by one of his sponsors. Nietzsche repudiates the usual conception of morality, which he calls slave-morality, in favor of a morality of masters. The former according to him encourages the deterioration of humanity; the latter promotes advancement. He favors a true aristocracy as the best means of producing a race of supermen. "Instead of advocating 'equal and inalienable rights to life, liberty, and the pursuit of happiness,' for which there is at present such an outcry (a régime which necessarily elevates fools and knaves, and lowers the honest and intelligent), Nietzsche advocates simple justice - to individuals and families according to their merits, according to their worth to society; not equal rights, therefore, but unequal rights, and inequality in advantages generally, approximately proportionate to deserts ; consequently, therefore, a genuinely superior ruling class at one end of the social scale, and an actually inferior ruled class, with slaves at its basis, at the opposite social extreme."

Since it is the view of this aristocratic philosopher that science is the ally of democracy - a view that every chapter of the history of science serves to dem- 
onstrate - it is of interest to review his opinion of the character of the scientist. For Nietzsche the scientist is not a heroic superman, but a commonplace type of man, with commonplace virtues. He lacks domination, authority, self-sufficiency; he is rather in need of recognition from others and is characterized by the self-distrust innate in all dependent men and gregarious animals. He is industrious, patiently adaptable to rank and file, equable and moderate in capacity and requirement. $\mathrm{He}$ has a natural feeling for people like himself, and for that which they require: A fair competence and the green meadow without which there is no rest from labor. The scientist shows no rapture for exalted views; in fact, with an instinct for mediocrity, he is envious and strives for the destruction of the exceptional man.

A training in natural science tends to make one objective. But the objective man, in Nietzsche's opinion, distrusts his own personality and regards it as something to be set aside as accidental, and a detriment to calm judgment. The temperamental philosopher thinks the scientist serene, but that his serenity springs not from lack of trouble, but from incapacity to grasp and deal with his own private grief. His is merely disinterested knowledge, according to Nietzsche. The scientist is emotionally impoverished. His love is constrained, and his hatred artificial; he is less interesting to women than the warrior. "His mirroring and externally self-polished soul no longer knows how to affirm, no longer how to deny; he does not command; neither does he destroy." As we see in the case of Leibnitz, the 
scientist contemns scarcely anything (Je ne méprise presque rien). The scientist is an instrument, but not a goal; he is something of a slave, nothing in himself - presque rien! There is in the scientist nothing bold, powerful, self-centered, that wants to be master. $\mathrm{He}$ is for the most part a man without content and definite outline, a selfless man.

This educational product, which the builders of modern aristocracy reject, and describe after their fashion, we accept as the ally of the masses of the people, and we term it democratic culture.

The objective man, at the same time, may find even in the vehement pages of Nietzsche warnings and criticisms which the friends of democracy should not disregard. Extreme, almost insane, as his doctrine undoubtedly is, it may have value as a corrective influence, an antidote for other extreme views. It serves to remind us that democracy may be misled by feelings in themselves noble, and may, by grasping what seems good, miss what is best. For example, there are in the United States about three hundred thousand persons, defective or subnormal mentally; there is a smaller number of persons exceptionally gifted mentally. It is a poor form of social service that would exhaust the resources of science and philanthropy to care for the former without making any special provision for the latter. Genius is too great an asset to be wasted or misapplied. All culture would have suffered if Newton had been held, in his early life, to exacting administrative work; or if Darwin had devoted his years to alleviating the conditions of the miners of Peru whose misery touched him so profoundly; or if Pasteur had 
been taken from the laboratory and pure science to make a country doctor. Nor can democracy rest satisfied with any substitute for culture which would disregard what is great in literature, in art, and in philosophy, or which would ignore history, and the languages and civilizations of the past, as if culture had its beginning yesterday.

In this chapter we have considered democracy and democratic culture from the standpoint of three writers on education, a Greek aristocrat, a German advocate of the domination of the classes over the masses, and an Oxford professor, all by training and temperament more or less hostile critics. A more direct procedure might have been employed to establish the claim of science to afford a basis of intellectual and social homogeneity. A brilliant literary man of the present day considers that places in the first ranks of literature are reserved for the doctrinally heterodox. None of the great writers of Europe, he asserts, have been the adherents of the traditional faith. (He makes an exception in favor of Racine: but this is a needless concession, for Racine owed his early education to the Port Royalists, became alienated from them and wrote under the inspiration of the idea of the moral sufficiency of worldly honor ; then, after an experience that shook his faith in his own code, he returned to the early religious influences in his life and composed his Esther and Athalie.) But, unlike literature, the study of science is not exclusive. In the front ranks of science stand the devout Roman Catholic Pasteur, the Anglican Darwin, the Unitarian Priestley, the Calvinist Faraday, the Quakers Dalton, Young, and Lister, Huxley the 
Agnostic, and Aristotle the pagan biologist. Science has no Test Acts.

That the cultivation of the sciences tends to promote a type of culture that is democratic rather than aristocratic, sympathetic rather than austere, inclusive rather than exclusive, is further witnessed by the fact that the tradesman and artisan, as well as the dissenter, play a large part in their development. We have seen that Pasteur was the son of a tanner, Priestley of a cloth-maker, Dalton of a weaver, Lambert of a tailor, Kant of a saddler, Watt of a shipbuilder, Smith of a farmer. John Ray was, like Faraday, the son of a blacksmith. Joule was a brewer. Davy, Scheele, Dumas, Balard, Liebig, Wöhler, and a number of other distinguished chemists, were apothecaries' apprentices. Franklin was a printer. At the same time other ranks of society are represented in the history of science by Boyle, Cavendish, Lavoisier. The physicians and the sons of physicians have borne a particularly honorable part.in the advancement of physical as well as mental science. The instinctive craving for power, the will to dominate, of which Nietzsche was the lyricist, was in these men subdued to patience, industry, and philanthropy. The beneficent effect of their activities on the health and general welfare of the masses of the people bears witness to the sanity and worth of the culture that prompted these activities.

As was stated at the outset of this chapter, education is the oversight and guidance of the development of the immature with certain ethical and social ends in view. The material of instruction, the method of instruction, and the type of educational institution, 
will vary with the hereditary endowment, age, and probable social destiny of the child. In a democratic country likely to become more, rather than less, democratic, those subjects will naturally be taught which have vital connection with the people's welfare and progress in civilization. At the same time the method of instruction will be less dogmatic and more inclined (under a free than under an absolute government) to evoke the child's powers of individual judgment; arbitrary discipline must yield gradually to self-discipline. The changes here indicated as desirable are already well under way in America. As regards types of educational institution, it is significant that America about the middle of the eighteenth century introduced the Miltonic, nonconformist Academy, with its science curriculum, in place of the traditional Latin grammar school. Later the American high school, institutions of which type now have over a million pupils, and teach science by the heuristic laboratory method, became the popular form of secondary school. It is, likewise, not without social significance that the Kindergarten was suppressed in Prussia after the revolt of the people in the middle of the nineteenth century, and that it found a more congenial home in a democratic country. Its educational ideal of developing self-activity without losing sight of the need of social adaptation finds its corollary in systematic teaching of the sciences in relation both to the daily work and to their historical and cultural antecedents. 


\section{REFERENCES}

Matthew Arnold, Essays in Criticism, and Culture and Anarchy. Matthew Arnold, Civilization in the United States.

Friedrich Nietzsche, On the Future of our Educational Institutions, vol. vi, of the Complete Works; translation edited by Dr. Oscar Levy.

Friedrich Nietzsche, Beyond Good and Evil, vol. v, chap. vı, of the Complete Works.

Plato, Republic, Book virr; vol. III, of Benjamin Jowett's translation of the Dialogues of Plato, 1875. 


\section{INDEX}

Académie des Sciences, 111, 112. Arnold, Matthew, 273.

Academy, at Athens, 19; Mil- Astrology, 10.

ton's plan, 102; Defoe's, 116; Astronomy, (Egyptian and BaFranklin's, 125; type of secondary school, 282.

Adams, John Couch, 188 et seq. Aerodynamics, 233.

Agricola, George, 129.

Agriculture, 12, 38, 107, 126, 137.

Air, 157.

Air craft, 71, 126, 231 et seq.

Air-pump, 96.

Akademie der Wissenschaften,

113.

Albertus Magnus, 53.

Alchemy, 50, 252.

Alcuin, $\mathbf{5 2}$.

Alexandria, 19, 44 et seq.

Algebra, 49.

Alkaline earths, 179.

American Philosophical Society, 121.

Anatomy, 6, 8, 38, 50, 78.

Anemometer, 107, 235.

Anthrax, 224 et seq.

Antipodes, 37, 48.

Antiseptic surgery, 220, 231.

Application, 30 et seq.

Aqua regia, 51, 132.

Aqueducts, 33.

Aqueous vapor, 157 et seq.

Arago, 184.

Archimedes, 27.

Architecture, 30 et seq.

Archytas, 18.

Aristotle, 20 et $8 e q ., 49,51,53$, 266.

Arithmetic, 6, 11, 48.

bylonian) 2 et seq.; (Greek) 16;

(Roman) 34; (Alexandrian) 45;

(Hindu) 48; (Arabian) 49, 50;

(Copernican) 55 ; (Tycho

Brahe and Kepler) 87 et seq.;

(Newton) 110 et seq.; (nebular hypothesis) 142 et seq.; (discovery of Neptune) 184 et seq.

Atmosphere, 157.

Atomic Theory, 158 et seq., 250.

Atoms, 17, 148, 158, 253.

Augustus Cæsar, 36.

Averroës, 51 et seq.

Avicenna, 51.

Avogadro, 165.

Babylonia, 1 et seq.

Bacon, Francis, 57 et seq., 80 et seq., 105; Baconian principles, 211.

Bacon, Roger, 54.

Bacteria, 93.

Bacteriology, 213 et seq.

Bagdad, 49.

Barbarians, 46.

Barometer, 94 et seq.

Basalt, 131, 132, 136, 137, 201.

Becquerel, 233, 246 et seq.

Beddoes, 173.

Beer, 223, 226.

Berzelius, 162.

Bessel, 187.

Biology, 6, 7, 23 et seq., 37, 53, 78, 109, 197 et seq., 213. 
Biot, 215 et seq.

Black, 129, 133.

Bode's Law, 189.

Botany, 6, 26, 37, 39, 53, 231 et seq.

Bouvard, Alexis, 185.

Bouvard, Eugène, 187.

Boyle, 96, 107.

Buffon, 130, 135.

Building material, 32.

Cabanis, 258.

Cairo, 49.

Calendar, 9, 36.

Carbonic acid, 138, 155, 157, 217.

Carlisle, 177.

Cato, 35, 38.

Challis, 189.

Charlemagne, 52.

Charles II, 105.

Chemical affinity, 159, 253.

Chemistry, 6, 8, 50, 51, 155 et seq., 170 et seq., 245 et seq.

Chicken cholera, 225.

Chlorine, 180.

Clocks, 89, 94.

Collinson, 123.

Columbus, 26, 54.

Columella, 38.

Comenius, 100.

Comets, 10, 40, 149.

Conservation of energy, 168.

Constantine, 37.

Copernicus, 55.

Coral reefs, 203.

Cordova, 50.

Counting, 6, 11, 34, 49, 86.

Cowley, 104 et seq.

Cronstedt, 130.

Curie, P. and S., 247 et seq.

D'Alembert, 58.

Dalton, 155,157 et séq.
Darwin, Charles, 198 et seq.

Darwin, Erasmus, 199.

Davy, 122, 163, 170 et seq.

Deduction, 82 .

Defoe, 116.

Democratic culture, 44, 270 et seq.

Democritus, 17, 48, 148.

Descartes, 57, 72, 82 et seq.

Desmarest, 132.

Dialogues of Plato, 19.

Diderot, 58.

Dioscorides, 39.

Dyes, 24, 33, 71, 181.

Earthquakes, 40, 137.

Ebers papyrus, 7.

Eclipses, 10, 16, 49.

Education, 19, 35, 36, 40, 44, 52. 53,100 et seq., 116, 122, 123, 171-72, 198, 213, 214, 216, 270 et seq.

Egypt, 1 et seq.

Electricity, 75, 123 et seq., 177, 231.

Electrolysis, 178.

Elements, 17, 20, 22, 155.

Ellipse, 20.

Embalmers, 7.

Empedocles, 17, 40.

Encyclopaedia, 58.

Ethics, 21, 40, 41.

Euclid, 18, 19.

Evelyn, 109.

Experiment, 72 et seq.

Extinction, 206.

Faraday, 181.

Fermentation, 216 et seq.

Fitzroy, 198.

Flacherie, 221.

Flamsteed, 110, 111, 184.

Fossils, 140.

Franklin, 15, 114. 
Galen, 38, 79.

Galileo, 75 et seq., 95.

Galipagos Archipelago, 208 et seq.

Galle, 193.

Galton, 258.

Galvani, 177.

Gascoigne, 93.

Gassendi, 99.

Gay-Lussac, 164, 181.

Geber, 177.

Geology, 129 et seq.

Geometry, 4, 15, 18, 19, 84, 264.

Gerbert, 53.

Gilbert, 72, 74, 76.

Glen Tilt, 136.

Gnomon, 13, 33.

Granite, 131.

Graunt, 105, 109.

Gravity, 110 et seq.

Greece, 15 et seq.

Gresham College, 101, 106.

Grew, 109.

Guericke, 96.

Hall, Sir James, 129, 137 et seq.

Halley, 110, 112, 186.

Hammurabi, 12.

Hartley, 172, 258.

Hartlib, 99.

Harun Al-Rashid, 48.

Heat, 82, 155, 156, 166, 168, 173.

Heliacal rising, 4.

Helmholtz, 168, 258.

Henry, 238.

Heraclitus, 17.

Herschel, Sir John, 192.

Herschel, Sir William, 152 et seq., 184.

Hindu arithmetic and astronomy, 48, 49.

Hipparchus, 27, 45.

Hippocrates, 27.

Hobbes, 99.
Homology, 26.

Hooke, 107, 109.

Hope, 138.

Horrocks, 109.

Horse, 204.

Horticulture, 40.

Hugo of St. Victor, 60.

Humboldt, 131, 201.

Hussey, 186.

Hutton, 132 et seq.

Huygens, 94, 111.

Hydrophobia, 207, 227 et seq.

Hypatia, 46, 48.

Hypothesis, 147, 150, 245 et seq.

I-em-hetep, 6.

Ilu-bani, 12.

Induction, 81, 177.

Industries, 8, 27, 68 et seq., 173, $182,220,223,226$.

Inoculation, 126.

Inventions, 107, 233 et seq.

Invisible College, 103.

Iodine, 181.

Iron, 8, 13, 182.

Isidore of Seville, 60.

James, William, 258, 261, 268.

Joule, 155, 167 et seq.

Julius Cæsar, 36.

Kant, 142, 145 et seq.

Kepler, 90 et seq., 110.

Kindergarten, 281.

Kircher, 93.

Lactantius, 48.

Lambert, 142, 149 et seq.

Langley, 231 et seq.

Laplace, 112, 150 et seq.

Laurium, 27.

Lava, 138.

Lavoisier, 156, 172.

Leeuwenhoek, 93. 
Leibnitz, 106, $112,277$.

Lenses, 40, 50.

Leonardo da Vinci, 72.

Leverrier, 190 et seq.

Libraries, 46, 48, 121.

Lincoln, 43 et seq.

Linnæus, 130.

Lippershey, 92.

Lister, 213, 220, 223.

Locke, 116, 172, 258.

Logarithms, 91.

Logic, 21, 53.

Lucretius, 40.

Lyell, 197, 201.

Magnetism, 75, 127.

Magnifiers, 40.

Malpighi, 93, 106, 109.

Malthus, 121, 211.

Manchester, 157.

Marble, 139.

Mars, 10, 91.

Marsh gas, 126, 163, 182.

Materia medica, 39, 51 .

Mathematics, 4, 5, 6, 10, 11, 15, $17,18,19,34,48,49,55,87$ et seq., 110 et seq., 184 et seq., 264.

Maupertuis, 145.

Mayow, 156.

Measuring, 5, 10, 86 et seq.

Mechanics, 18, 77, 231 et seq.

Medicine, 6, 11, 27, 34, 126, 173 et seq., 207, 216 et seq.

Mensuration, 5, 92.

Mental imagery, 263.

Mercury, 50, 51, 156.

Mersenne, 99, 112.

Metallurgy, 8, 13, 23, 50.

Meteorology, 122, 133, 158.

Microscope, 93.

Milky Way, 144.

Mill, John Stuart, 256.

Milton, 102, 213.
Mineralogy, 130.

Minute and second, 46.

Monochord, 17.

Monte Cassino, 52.

Moray, 104, 112.

Murex, 24, 33.

Napier, 91.

Napoleon I, 151, 177, 214.

Napoleon III, 221.

Natural history, 23, 37, 52, 61.

Navigation, 3, 16, 26, 54, 126, 231.

Nebular hypothesis, 147, 150.

Neptune, 184 et seq.

Neptunist, 131.

New Atlantis, 71, 100, 183.

Newton, 110, 135, 158.

Nicholson, 177.

Nietzsche, 277 et seq.

Nitric oxide, 156, 161.

Nitrous oxide, 174.

Novum Organum, 70, 72.

Numerals, 6, 11, 34, 49, 87, 231.

Observatories, 4, 49.

Occupations, 12, 51, 58, 68 et seq., 107.

Optics, 50, 54, 93.

Organic remains, 126, 140.

Origin of the sciences, $1 \mathrm{et} \mathrm{seq.}$

Origin of Species, 201.

Pansophy, 100.

Pascal, 95, 117.

Pasteur, 213 et seq.

Pearson, Karl, 60.

Peirce, 195.

Pepys, 110.

Petty, 103, 122.

Peurbach, 55.

Philosophical Transactions, 109.

Philosophy, 15 et seq., 134. 
Physics, 21, 28, 31, 32, 50, 54, 74 et seq., 94 et seq., 110 et seq., 123, 155 et seq., 170 et seq., 231 et seq., 245 et seq.

Physiology, 6, 21, 38, 78, 173 et seq., 225 et seq.

Picard, 111.

Plato, 18, 270 et seq.

Playfair, 133, 137.

Pliny, 37.

Pneumatic Institution, 173.

Poincaré, Henri, 255, 267.

Port Royal, 116, 279.

Potash, 23, 51, 179.

Potassium, 179.

Precession of the equinoxes, 10, 112.

Priestley, 126, 156.

Primitive man, 206.

Principia, 110, 114.

Prism, 40.

Protyl, 254.

Psychology, 23, 256 et seq.

Ptolemy, 45, 55.

Pythagoras, 17.

Quadrants, 50, 86.

Quintilian, 39.

Rabies, 287 et seq.

Racemic acid, 215.

Radioactivity, 245 et seq.

Ramsay, 246.

Ray, 110.

Regiomontanus, 55.

Religion, 3, 8, 10, 40, 43 et seq., 142 et seq.

Rey, 94.

Rhind papyrus, 6 .

Röntgen rays, 231.

Rousseau, 270.

Royal Institution, 176.

Royal Society of Edinburgh, 133.
Royal Society of London, 99 et seq.

Rumford, 166.

Rutherford, 247 et seq.

St. Benedict, 52 .

St. Thomas Aquinas, 53.

Saturn, 2, 92, 145.

Saussure, 133.

Scheele, 156, 180.

Scientific apparatus, 17, 49, 86 et seq.

Scotus Erigena, 53.

Seneca, 40.

Shaftesbury, 117.

Signs of zodiac, 9, 33.

Silkworm, 109, 221 et seq.

Siphon, 95.

Sirius, 4.

Smith, Adam, 121, 133, 256.

Smith, William, 139 et seq.

Smithsonian Institution, 195, 233, 238.

Socrates, 44, 117.

Soda, 8, 51, 179.

Soddy, 248 et seq.

Sodium, 179.

Sosigenes, 36.

Sound, 33.

Species, 24, 197 et seq.

Specific gravity, 28, 36, 50.

Spectrum analysis, 153, 231.

Sphericity of the earth, 26, 37.

Spontaneous generation, 25,218 .

Sprat, 105, 109.

Steel, 8, 23.

Sundial, 13.

Survival, 206.

Syntaxis, 45.

Tables, astronomical, 49, 50, 91,

185 et seq.

Tanning, 177. 
Technology, 5, 16, 20, 27, 30 et seq., 50,68 et seq., 86 et seq., $103,107,126,129,130,139-$ $41,156,160,167,177,182,231$.

Thales, 15.

Theology, 47, 62, 172.

Theon, 46.

Theophrastus, 26, 39.

Theory, 30, 41; T. of the Earth, 133.

Tides, 38, 112.

Torricelli, 95.

Trade and trades, 12, 51, 68 et seq., 107, 115, 118.

Transformation Theory, 249 et seq.

Trigonometry, 46, 49, 55 .

Turgot, 121.

Tycho Brahe, 87 et seq.

Tyndall, 260-61.

Uranus, 184 et seq.

Vacuum, 95.

Varro, 38.

Vesalius, 78.

Vitruvius, 30 et seq.

Viviani, 94.

Vivisection, 38, 71, 80.

Volcanoes, 40, 136.

Volta, 177.

Vulcanist, 131, 137.
Wadham College, 104.

Walker, 195.

Wallace, 211, 231.

Wallis, 103.

War, 46, 178, 213 et seq.

War-engines, 28, 34.

Watch, 94.

Water, 157, 177.

Water-clocks, 13, 94.

Watt, Gregory, 172.

Watt, James, 133, 156, 157.

Wedgwoods, 138, 173, 199.

Weighing, 7, 10, 86.

Werner, 129 et seq.

Wilkins, 101, 104.

Willis, 104.

Willughby, 109, 110.

Wine, 220, 226.

Wollaston, 119.

Wool, 226.

Wren, 104, 107.

Wright, 143 et seq.

Wundt, 258, 259.

Xenophon, 117.

Young, 258, 279.

Zacharias, 92.

Zodiac, 9, 33.

Zoölogy, 7, 12, 21, 24, 25, 37, $53,66,109,110,197$ et seq. 2 ß 


W.

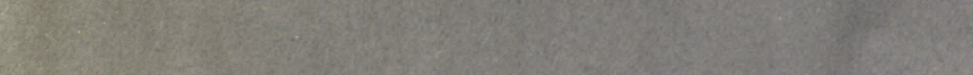
150. 3. Whes

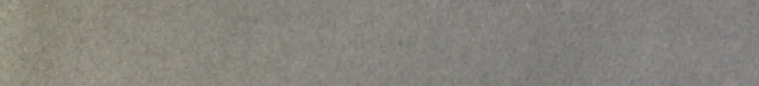

20 WelW.

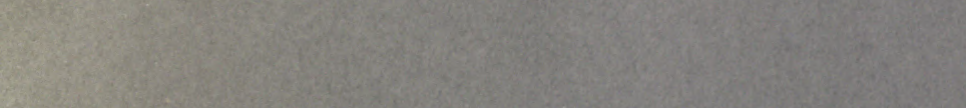
2.

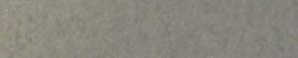
(2) (2) S.7.

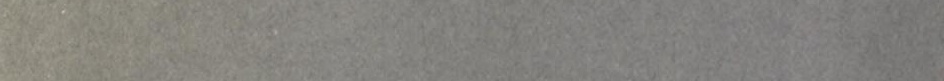

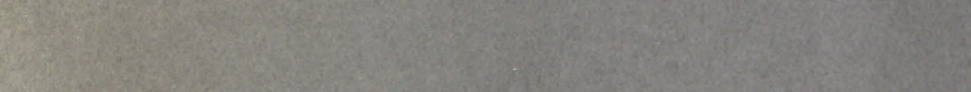

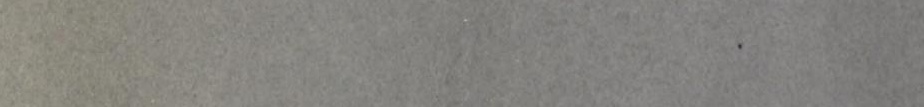

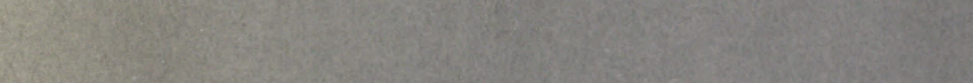
W6. 3. W.

(8) S. (2)

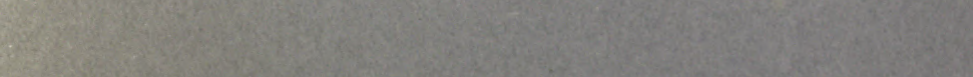

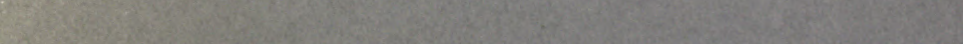

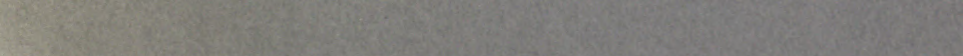
Wow Q Whas (2)

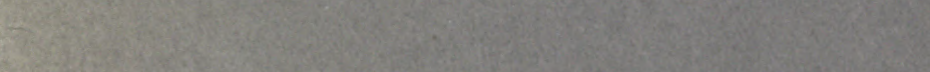

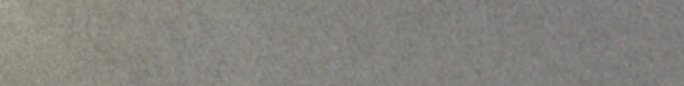

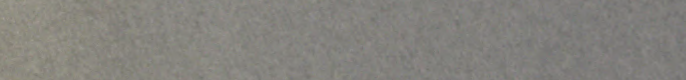

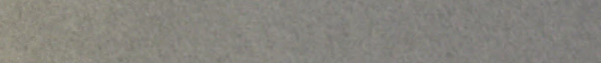
NWom 63. 


\section{UNIVERSITY OF CALIFORNIA LIBRARY BERKELEY}

Return to desk from which borrowed.

This book is DUE on the last date stamped below.

LIBRARY USE MAY 151955 MAY 151955 LI

1May'57BRE

REC'D LD

MAY 1 DEC 28 ECS -2 YM

7 Jan'59JBZ APB $35-1966$ o 1 MAY 61961 JUN 61968 RE'W'G'GBWS

REC'D LD

DEC 171958

17 May'61lu

IN STACKS

CT 101967

CCT $801801 \% 8$

MAR 1983 MAY23.68 . PM MAR2 $81870 \quad 48$

REC'D LD MAR $14^{\circ} 70$-1PH MAY $20^{i 91}$ OS

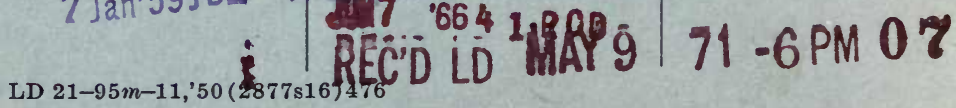




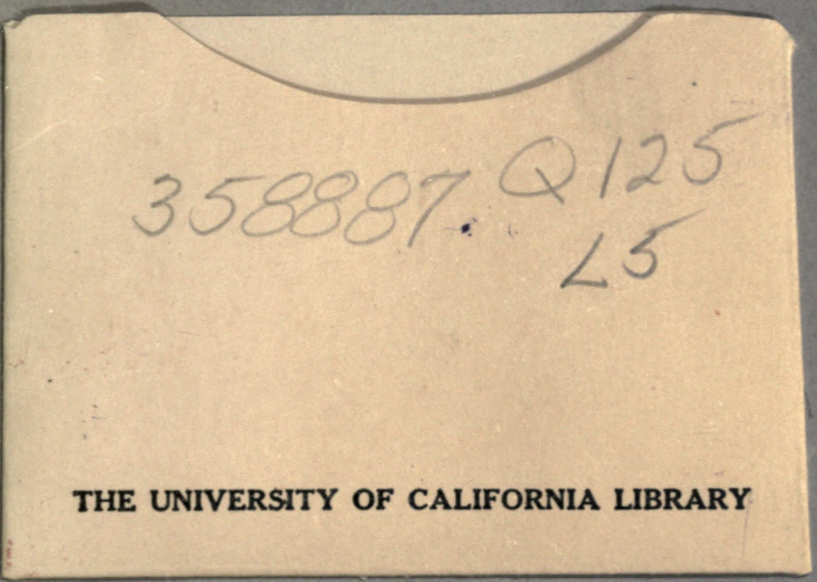


196.

if sing

$$
\text { and }
$$

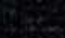

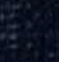

$-3$

cosent

2.

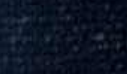

